\title{
Camp Mabry Archaeological Survey and Testing, Travis County, Texas
}

Richard S. Jones

Center for Archaeological Studies

John J. Leffler

Center for Archaeological Studies

Follow this and additional works at: https://scholarworks.sfasu.edu/ita

Part of the American Material Culture Commons, Archaeological Anthropology Commons, Environmental Studies Commons, Other American Studies Commons, Other Arts and Humanities Commons, Other History of Art, Architecture, and Archaeology Commons, and the United States History Commons

Tell us how this article helped you.

This Article is brought to you for free and open access by the Center for Regional Heritage Research at SFA ScholarWorks. It has been accepted for inclusion in Index of Texas Archaeology: Open Access Gray Literature from the Lone Star State by an authorized editor of SFA ScholarWorks. For more information, please contact cdsscholarworks@sfasu.edu. 


\section{Camp Mabry Archaeological Survey and Testing, Travis County, Texas}

Creative Commons License

(c) (i) (8)

This work is licensed under a Creative Commons Attribution-NonCommercial 4.0 International License 


\section{Camp Mabry Archaeological Survey and Testing, Travis County, Texas}

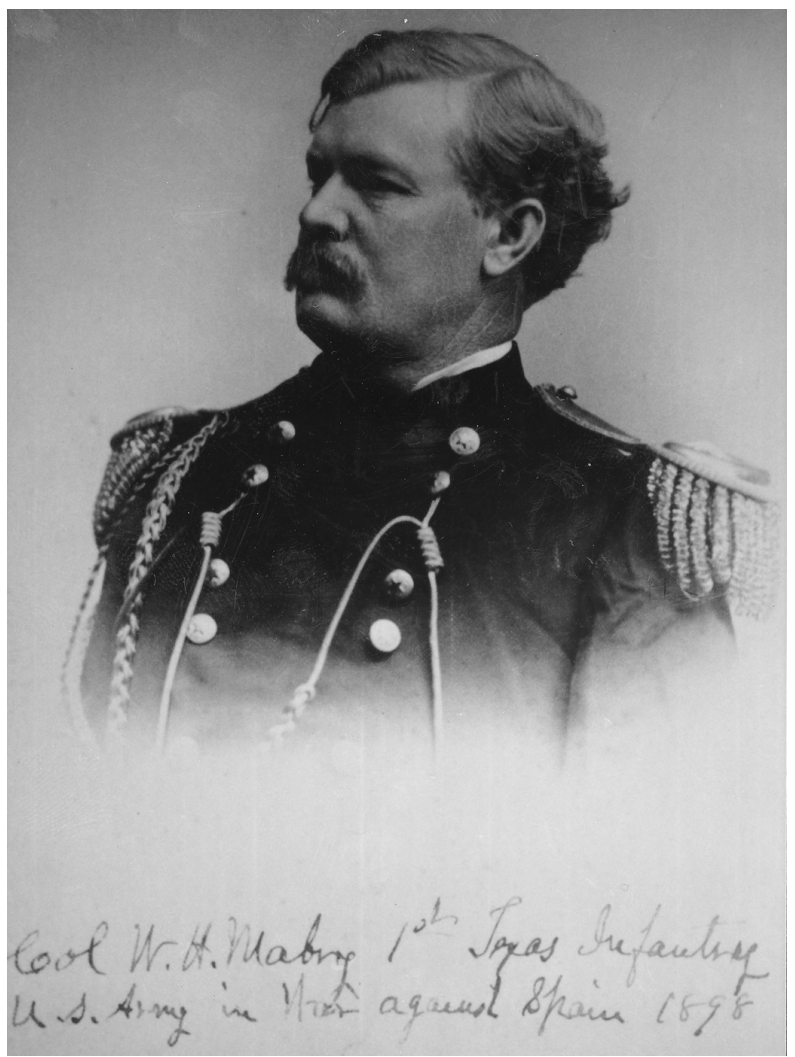

by

Richard S. Jones and John J. Leffler

Principal Investigators: C. Britt Bousman and David L. Nickels

Texas Antiquities Permit Number 2686

Archaeological Studies Report No. 2

Series Editor: Karen Elliott Fustes

Center for Archaeological Studies

Southwest Texas State University 


\title{
Camp Mabry Archaeological Survey and Testing, Travis County, Texas
}

\author{
by \\ Richard S. Jones and John J. Leffler \\ Principal Investigators: C. Britt Bousman and David L. Nickels
}

Texas Antiquities Permit Number 2686

Archaeological Studies Report No. 2

Series Editor: Karen Elliott Fustes

Center for Archaeological Studies

Southwest Texas State University

2002 
The following information is provided in accordance with the General Rules of Practice and Procedure, Chapter 41.11 (Investigative Reports), Texas Antiquities Committee:

1. Type of investigation: Survey and limited testing

2. Project name: Archaeological Survey and Testing of Camp Mabry, Travis County Texas

3. County: Travis

4. Principal investigators: C. Britt Bousman and David L. Nickels

5. Name and location of sponsoring agency: The Adjutant General's Department of Texas, Directorate of Facilities and Engineering, Environmental Branch, Austin, Texas

6. Texas Antiquities Permit No. 2686

7. Published by the Center for Archaeological Studies, Southwest Texas State University, 601 University Drive, San Marcos, Texas 78666 (2002)

Copyright 2002 - All rights Reserved

For further information on this and other publications by the Center for Archaeological

Studies, please contact:

Center for Archaeological Studies, Southwest Texas State University

601 University Drive, San Marcos, Texas 78666 


\begin{abstract}
In October 2001, the Center for Archaeological Studies (CAS) was contracted by the Adjutant General's Department of the Texas Army National Guard (AGTX) to perform a 100\% systematic archaeological survey on the grounds of Camp Mabry, in Austin. The project was comprised of a pedestrian survey, extensive shovel testing, and the excavation of two backhoe trenches. The survey resulted in the discovery of an 8 x 8-meter prehistoric site, 41TV1954. In addition, two previously recorded archaeological sites (41TV1667 and 41TV1722) were revisited, and shovel tests were excavated in order to reevaluate and document cultural resources and site boundaries. Based on data generated during the pedestrian survey and shovel testing, CAS has determined that 41TV1722 and 41TV1954 are not archaeologically significant and thus do not qualify for National Register consideration. After analyzing the results gathered from both shovel test and backhoe trench excavations on 41TV1667, CAS has concluded that the site does pose a moderate to high research potential. CAS thus recommends that further testing is needed on 41TV1667 in order to determine the site's eligibility for nomination to the National Register of Historic Places.
\end{abstract}




\section{Contents}

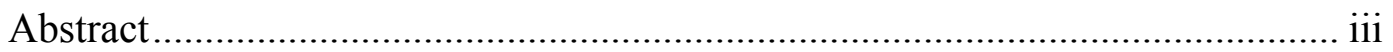

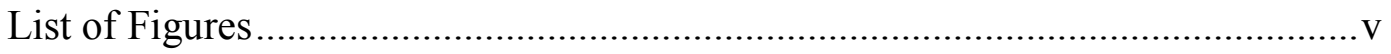

List of Tables ...................................................................................... vii

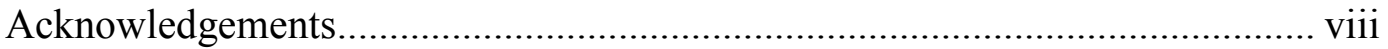

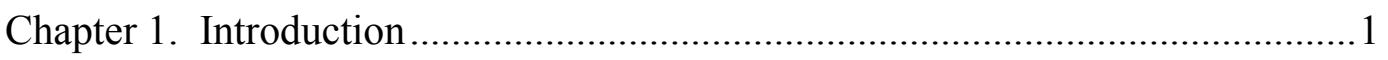

Chapter 2. Geologic and Environmental Context........................................... 3

Chapter 3. Archaeological and Cultural Background ........................................ 9

Chapter 4. History of Camp Mabry ............................................................ 16

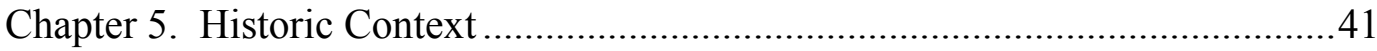

Chapter 6. Goals and Methodology …...................................................5

Chapter 7. Site Descriptions and Results...................................................56

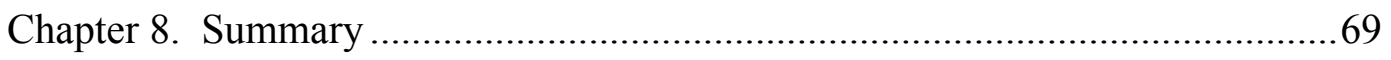

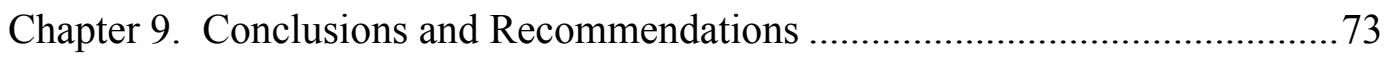

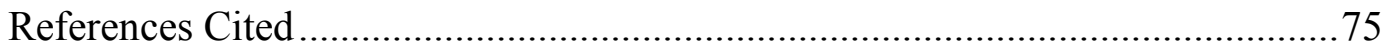




\section{List of Figures}

1. Austin area map with Camp Mabry highlighted ................................................. 1

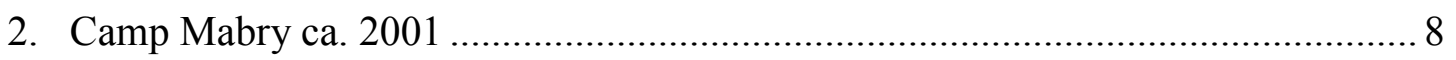

3. Camp Mabry and the surrounding area in 1902................................................. 16

4. Land Grants in the vicinity of Camp Mabry.......................................................18

5. Acquisition Map of Camp Mabry …………………………............................. 19

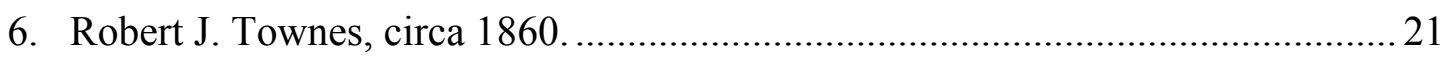

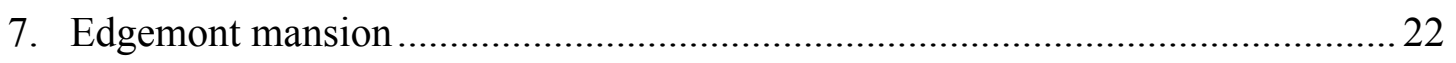

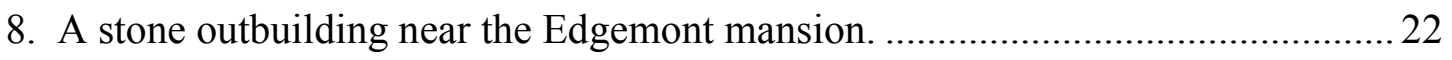

9. Map of Camp Mabry and the immediate vicinity in 1906 ....................................2 24

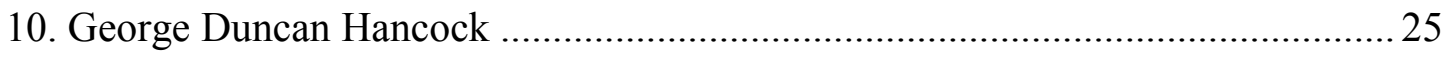

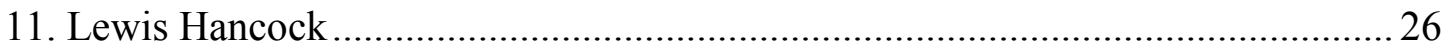

12. The Negro Deaf and Dumb Asylum, established 1887 .......................................2 29

13. W.H. Mabry, Adjutant General of Texas, 1891-1898 _.......................................... 31

14. An advertisement for the Texas Volunteer Guard's 1892 annual encampment....33

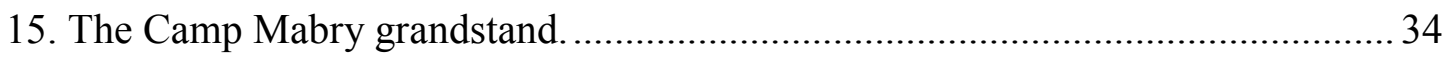

16. Women visiting Camp Mabry, circa 1890s............................................................. 34

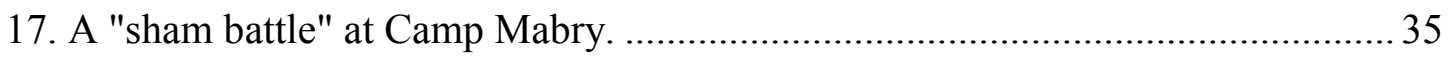

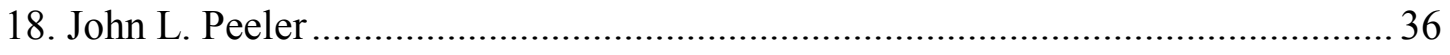

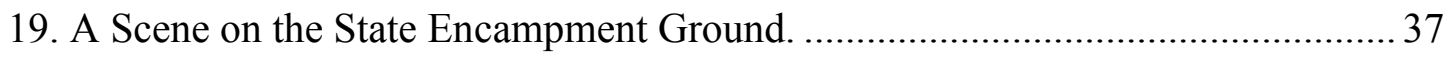

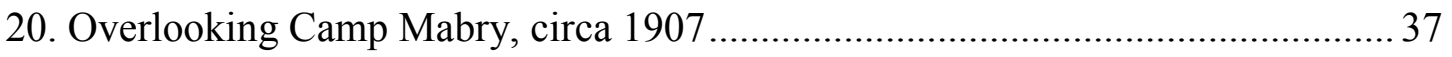

21. Photograph of Britt Bousman standing on one of the artificial terraces ............... 49

22. Map of Camp Mabry showing site and shovel test locations...................................51 
23. Photograph of CAS archaeologist excavating shovel test

24. Photograph of 41 TV1722.

57

25. Map of 41TV1722 showing the location of shovel tests.................................57

26. Unidentified projectile point tip recorded on the surface of $41 \mathrm{TV} 1722$..............58

27. Photograph of 41 TV1667 showing Barrow Brook in the foreground ...................59

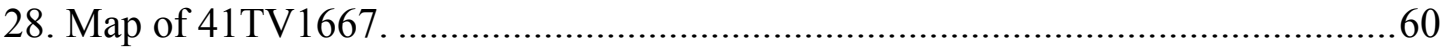

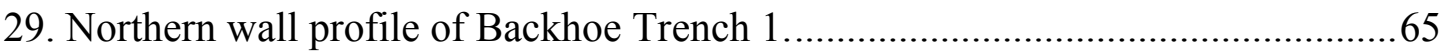

30. Northern wall profile of Backhoe Trench 2 ....................................................66

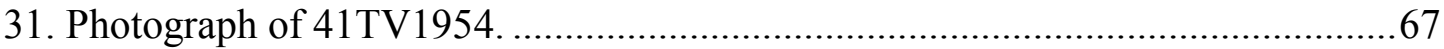

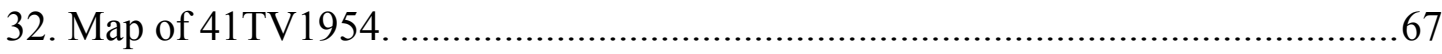




\section{List of Tables}

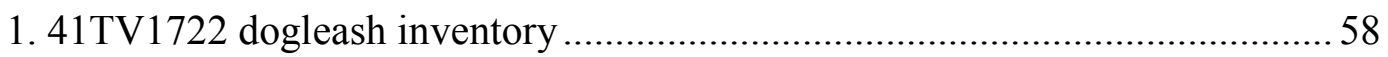

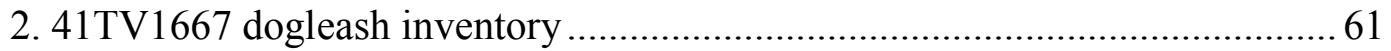

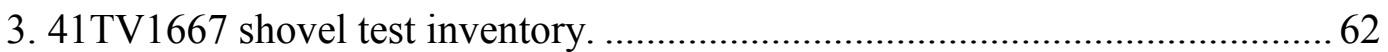

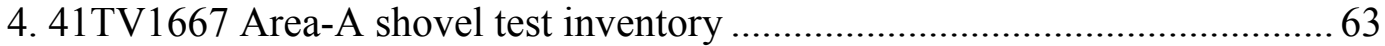

5. 41TV1667 Area-B shovel test inventory ....................................................63

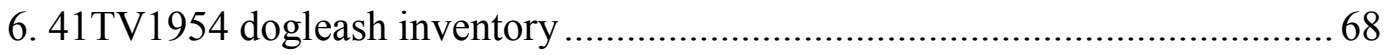

7. Contingency table showing the quantity and adjusted residuals of surface artifacts recorded on 41TV1667, 41TV1722, and 41TV1954 .......................70 


\section{Acknowledgements}

The authors would like to thank Britt Bousman and David Nickels for giving us professional advice and guidance throughout the project. Shellie Sullo-Prewitt, Cultural Resource Manager at Camp Mabry, provided extensive cooperation and support throughout the entire project. The project's fieldwork would not have been completed without the hard work and assistance of CAS staff archaeologists Antonio Padilla, Jimmy Barrera, and Melissa Lehman. The author would also like to thank CAS staff archaeologist Connie Gibson for her diligent work in artifact curation. CAS staff member Ray Umscheid worked long hours and contributed his expertise in illustration and GIS. This report could not have been completed without the expert work of CAS Reports Editor Karen Fustes. 


\section{Chapter 1: Introduction}

By Richard S. Jones

During September and October 2001, the Center for Archaeological Studies (CAS) at Southwest Texas State University (SWT) was contracted by the Adjutant General's Department of the Texas Army National Guard (herein after referred to as AGTX) to conduct an intensive 275-acre archaeological survey on the grounds of Camp Mabry. Camp Mabry, located within the city of Austin in Travis County (Figure 1), is one of the more significant bases for the Guard. In addition to housing the Adjutant General's Department of Texas, Camp Mabry is also the headquarters of the 49th Armored Division (Camp Mabry 2002). Limited military training and maneuvers are presently conducted within the 375 -acre confines of Camp Mabry.

The AGTX currently owns and carries out training and military preparedness activities on millions of acres of archaeologically sensitive land within the State of Texas. This vast property, which is managed by the AGTX, is primarily utilized for military field training and maneuvers. In order to manage the cultural resources within their property, while also maintaining a high degree of military readiness, the AGTX adopted an Integrated Cultural Resource Management Plan (ICRMP). This 275-acre Camp Mabry survey was implemented under the auspices of the AGTX in order to aid in the development of a cultural resource management plan for the camp.

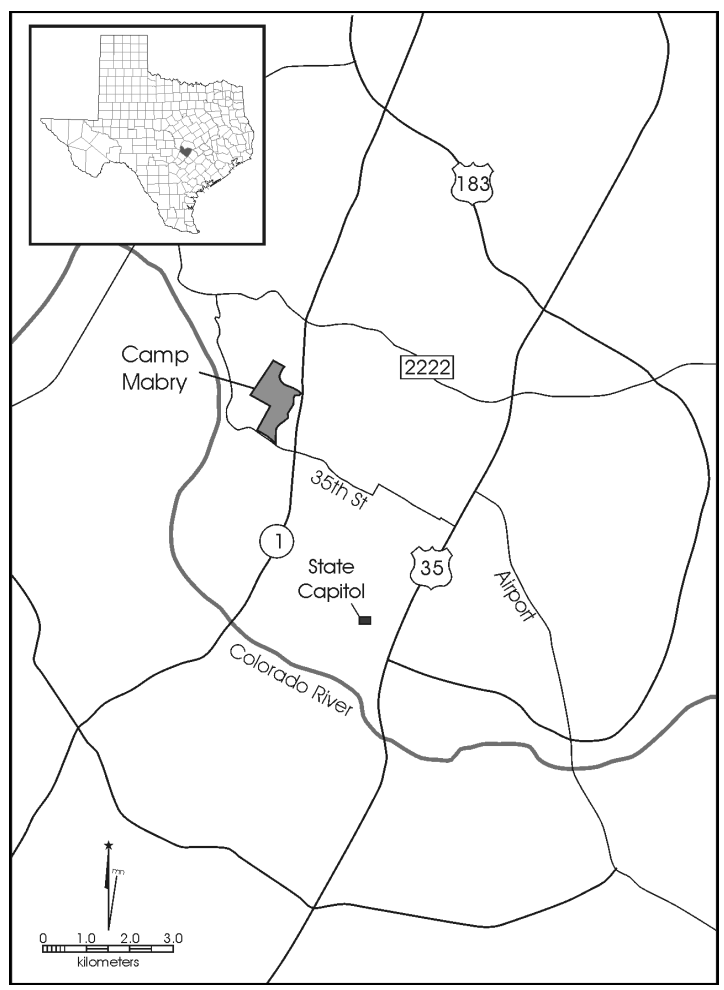

Figure 1. Austin area map with Camp Mabry highlighted. State of Texas and Travis County inset. 


\section{Project Objective and Description}

The primary objective in conducting this 275 -acre survey was to identify and document cultural resources within Camp Mabry and make appropriate recommendations concerning their eligibility to the National Register of Historic Places (NRHP). The NRHP eligibility recommendations to be made by CAS fell into one of three categories: 1) eligible, 2) not eligible, or 3) further investigation needed. In order to investigate the cultural resources of Camp Mabry, CAS conducted a 100\% survey consisting of: 1) a pedestrian survey, 2) shovel test and backhoe excavations, and 3) thorough investigation of previously recorded archaeological sites. In addition to the field survey, historian John Leffler conducted background research in order to develop the early history of Camp Mabry. The Texas Historical Commission (THC) issued CAS Texas Antiquities Permit 2686.

This survey resulted in the discovery of one 8-x-8-meter prehistoric archaeological site, which was subsequently assigned archaeological site trinomial 41TV1954. Upon investigation, the site was found to be severely impacted by both natural and artificial disturbances. Due to the high degree of disturbance noted, CAS recommended that the site not be considered eligible for nomination to the NHRP. During the survey, previously recorded archaeological sites 41TV1722 and 41TV1667 were revisited and tested in order to reevaluate their potential for NRHP eligibility. 41TV1722, like 41TV1954, was severely impacted by natural and artificial disturbances. Due to the high degree of disturbance noted, CAS recommended that 41 TV1722 be considered not eligible for nomination to the NRHP. During the survey, deep deposits of cultural resources were observed in a deep and undisturbed Holocene fill context (90+ $\mathrm{cm}$ ) within the southern portion of 41TV1667. Undisturbed Holocene fill deposits were not observed elsewhere during the intensive survey conducted on Camp Mabry. CAS determined that 41TV1667 poses a moderate to high degree of research value, and further testing is recommended in order to determine the nature of cultural resource deposition in this geomorphologically unique context. Therefore, further testing is recommended in order to determine the site's eligibility for the NRHP.

\section{Report Organization}

This report is divided into nine chapters. In Chapter 2, the environmental and geologic setting for the project area is discussed. Chapter 3 contains the prehistoric cultural chronology and archaeological background. The early history of Camp Mabry is presented in Chapter 4. The project's historic context is discussed in Chapter 5. Chapter 6 discusses the goals and methodology employed during the Camp Mabry survey. The results gathered from investigations on Camp Mabry's prehistoric sites are discussed in Chapter 7. A brief summary of the project is outlined and discussed in Chapter 8. The conclusions and NRHP eligibility recommendations for sites investigated are discussed in Chapter 9. 


\section{Chapter 2: Geologic and Environmental Context}

\section{Balcones Fault Zone}

Camp Mabry is located within a geographically complex and dynamic region known today as the 'Balcones fault zone.' The Balcones fault zone functions as a geologic transitional zone or ecotone, which effectively separates major physiographic, biotic, and vegetative provinces within Central Texas. The major tectonic events that are responsible for the creation of the Balcones Fault zone are thought to have occurred during the Cretaceous and Miocene Epochs. According to Woodruff and Abbott (1986),

The main tectonic events of Balcones faulting are generally thought to have occurred during the Miocene, but there is considerable evidence that periodic structural adjustments also took place in the Cretaceous. For example, mafic alkalic volcanic plugs of Late Cretaceous age occur at the surface and in the subsurface all along the Balcones fault zone. The geochemistry and petrology of these igneous rocks suggest that they penetrated the entire crust of the Earth.

During the Miocene, the majority of tectonic movements within the Balcones fault zone occurred predominately along a group of normal faults, which created an "upthrown" west side and an "downthrown" east side. Within some portions of the Balcones fault zone, movements along normal faults raised regions to the west approximately 2000 feet in elevation (Spearing 1991:113). Currently, evidence indicates that faulting within the Balcones fault zone has ceased. Earthquakes have not been detected within the Balcones fault zone since the creation and use of seismic instruments (Jordan 2002).

\section{Balcones Escarpment}

The creation of the Balcones fault zone set off an on-going and complex geologic chain of events, which is responsible for the present landscape observed today in Central Texas. After the Balcones fault zone was created, ancient west to east running Tertiary river systems started to divert away from their ancient courses, following the northeast to southwest strike direction of the numerous Balcones zone faults (Woodruff and Abbott 1986:84). As water flowed over the Balcones fault zone, the less resistant geologic deposits on the eastern side (e.g., Austin Group formations) began to erode at a faster rate than the highly resistant deposits encountered on the western side (e.g., Glen Rose and Edwards Limestone formations). Over millions of years this process, which is geologically labeled 'differential erosion,' effectively eroded away the weaker eastern deposits 200-700 feet below the stronger western deposits. This area, where steep and drastic changes in elevation occurred as a result of differential erosion, is geographically known as the Balcones Escarpment (Jordan 2002). The Balcones Escarpment was noted 
during the survey running in a north-south direction through the central portion of Camp Mabry. Thus, Camp Mabry is, in essence, divided in half between the Edwards Plateau to the west and the Blackland Prairie to the east.

\section{Edwards Plateau}

The region west of the Balcones fault zone is geographically known as the Edwards Plateau. The Edwards Plateau can be described as an elevated 240 x 480kilometer area, mainly comprised of strong, resistant Cretaceous limestone and dolomites originating from various geologic groups (e.g., Trinity, Woodbine, Glen Rose, Walnut, Edwards, and Fredericksburg). Having been exposed to the elements for millions of years, the landscape of the Edwards Plateau shows signs of extensive wear and scarring. Over time, water has managed to extensively dissolve the limestone/karst topography, forming extensive subterranean cavities and sinkholes. Filled with water, these caverns form the foundation for the Plateau's vast sub-surface aquifer hydrology. During the Miocene epoch, aquifers located in proximity to the Balcones fault zone (e.g., Edwards and Trinity aquifers) were perforated by tectonic movements, hence forming the numerous clear springs (e.g., Comal and San Marcos springs) observed in Central Texas today (Spearing 1991:113).

\section{Balcones Canyonlands}

The topography encountered within far eastern portions of the Edwards Plateau (adjacent to the Balcones Escarpment) is quite different than that encountered on central portions of the Plateau. In areas to the west of the Balcones Escarpment, young formations of "upthrown" geologic deposits (e.g., Edwards Group) form the steep and relatively rugged topography, which is often labeled the "Balcones Canyonlands" (Kibler and Scott 2000:5). During this survey, the western half of Camp Mabry displayed the topographic characteristics associated with this type of geographic setting. In certain areas within western portions of Camp Mabry, outcrops of Edwards Group limestone formations were observed exposed at steep angles, forming moderately incised valleys and drainages. Barrow Brook (a small seasonal tributary to the Colorado river), was noted running in a north-south direction within the moderately incised western portion of Camp Mabry.

\section{Blackland Prairie}

Since the late Tertiary, the majority of soils once deposited on the Edwards Plateau have eroded to lower elevations east of the Balcones Escarpment, in an area known as the Blackland Prairie physiographic province (Black 1989a). Within the 
Blackland Prairie, rich deposits of late Tertiary and Quarternary calcareous clay soils have managed to accumulate (without interruption) to great depths. Due to the rich, deep accumulation of soils within the Blackland Prairie, this region has been extensively used for agricultural purposes since European colonization. Geographically, the Blackland Prairie is an area of relative low topographic relief and poor drainage that is prone to frequent flooding (Collins 1995). The Eastern portion of Camp Mabry is located within this physiographic province.

\section{Hydrology}

\section{Surface Hydrology}

Camp Mabry is located within the Colorado River Basin of Central Texas. The Colorado River basin covers an estimated 600 linear miles, drains approximately 3,803,900 acre-feet of water within 39,893 square miles of land, and contains 11 major reservoirs (Bureau of Economic Geology 1996). Lake Travis, located $1.5 \mathrm{~km}$ west of Camp Mabry, was created in 1939 when the Marshall Ford Dam was erected along the Colorado River. Currently, Lake Travis is approximately 778,000 acre-feet in size and holds an estimated 1,950,000 acre-feet of water (LAKE TRAVIS 2002). Barrow Brook, located in the western portion of Camp Mabry, was the most prominent surface hydrologic feature observed within the project area. It appears the entire western section of Camp Mabry drains into this small brook. During the survey, a 150 x 300-meter artificial lake (Lake Mabry) was observed within the southern section of Camp Mabry. This lake was created by the damming of an unnamed and ephemeral creek located within the central project area (Figure 6). In the construction of this lake, an estimated $600 \times 200$-meter area in the center of Camp Mabry was extensively impacted from bulldozing and grading activities.

\section{Underground Hydrology}

The western portion of Camp Mabry is located over a part of the Cretaceous-age Edwards Aquifer. The aquifer is a very unique carbonate aquifer located in south-central Texas, and extends under the major areas of nine counties within Central Texas: Kinney, Uvalde, Medina, Bexar, Comal, Hays, Travis, Williamson, and Bell. From Kinney to Bell Counties, the aquifer measures approximately 220 miles long and varies in width from 5 to 40 miles (Texas Water Development Board 1990). The Edwards Aquifer traverses several streams in four major river basins including: the Nueces, Colorado, San Antonio and Guadalupe (Bureau of Economic Geology 1996). The limestone/karst characteristics (e.g., porous Cretaceous geology) of the Edwards make it one of the most productive aquifers in the United States and the most prominent underground hydrologic feature within the project area (EARDC 2002). 


\section{Soils}

Due to the project area's location within a transitional geologic zone, a wide variety of soils were encountered within the confines of Camp Mabry. Within the upland, Balcones Canyonland setting of western Camp Mabry, the soils consisted mainly of stony/shallow deposits of Tarrant and Brackett soils. According to Werchan et al. (1974:45), Tarrant and Brackett soils are commonly observed occupying narrow ridges, valleys, and side slopes. Tarrant and Bracket soils generally extend 6-9 inches below the surface, with soft limestone bedrock encountered at the base.

Within the low Blackland Prairie setting of eastern Camp Mabry the soils consisted mainly of moderately deep deposits of Volente soils. According to Werchan et al. (1974:43), Volente soils are commonly observed occupying valleys and foot slopes. In certain areas, Volente soils can extend to 3 feet in depth. Below 46 inches a reddishyellow calcareous clay loam typically forms the underlying material.

\section{Flora and Fauna}

Again, due to the fact that Camp Mabry is located in a geographic and ecologic transition zone that separates two major physiographic provinces, the flora and fauna noted within the project area consist of a mixture of Edwards Plateau and Blackland Prairie species.

\section{Flora}

Portions of Camp Mabry reside within the Juniper-Oak-Mesquite Savanna vegetative region (Black 1989a), and the Edwards Plateau and Blackland Prairie vegetative regions as defined by Gould (1969). Flora noted during the survey included vegetative species indigenous to all three regions, consisting of: Texas oak (Quercus buckleyi), cedar elm (Ulmus crassifolia), mesquite (Prosopis juliflora), ash juniper (Juniperus ashei), buffalo grass (Buchloe dactyloides), grammas (Bouteloua spp.), bluestem (Schizachyrium scoparium var. frequens), prickly pear (Opuntia lindheimeri), greenbrier (Smilax bona-nox) and various mosses.

\section{Fauna}

Portions of Camp Mabry reside within the Balconian and Texan biotic provinces as defined by Blair (1950). White-tailed deer (Odocoileus virginianus), Badger (Taxidea taxus), eastern cottontail rabbit (Sylvilagus floridanus), raccoon (Procyon lotor), opossum (Didelphus virginiana), coyote (Canis latrans), rattlesnake (Crotalus sp.), painted turtle 
(Chrysemys sp.), fox squirrel (Sciurus niger) and turkey (Meleagris gallopavo) are just a few of the fauna typically noted within this transitional ecologic zone.

\section{Climate}

Camp Mabry resides within a climatic zone of convergence where warm moist Gulf air collides with cool and dry northern air masses, triggering atmospheric instability and heavy periods of rainfall. The average yearly precipitation is 32.5 inches; monthly means have a bimodal distribution (Woodruff 1975:4) with periods of high rainfall in May and September (Werchan et al. 1974:120).

The modern climate of Camp Mabry is warm, humid, and subtropical (Texas Department of Water Resources 1981). Summers are usually hot, with average daily maximum temperature of $91.4^{\circ} \mathrm{F}$ (Texas Department of Water Resources 1981). Winters are generally mild, with a $39.4^{\circ} \mathrm{F}$ low and $64.1^{\circ} \mathrm{F}$ high average temperature range (Werchan et al. 1974:117).

\section{Camp Mabry's Modern Landscape}

The present landscape of Camp Mabry has changed significantly since it was first established as an operational military post in 1892. In 1906, the Camp Mabry maneuver grounds consisted of approximately 400 acres of property located on the western outskirts of Austin. In the past 95 years the AGTX has sold approximately 25 acres to the rapidly expanding City of Austin. Camp Mabry currently operates on an estimated 375 acres of property, which is presently located well within the City of Austin (see Figure 1).

In addition to losing a small amount of property to Austin, Camp Mabry has been impacted from extensive construction and landscape alterations. Of the 275 acres of property within this survey project, roughly 50 percent ( 137.5 acres) was highly impacted by artificial disturbances. Most of the highly disturbed areas were observed on the eastern half of Camp Mabry (Figure 2). Large artificial landfill and steep terrace constructions were responsible for impacting approximately 85 acres of property, while road/structure construction activities impacted roughly 53 acres. 
FIGURE 2. REDACTED

Figure 2. Camp Mabry ca. 2001 showing surveyed area and site locations.

A total of 137.5 acres were considered relatively undisturbed in nature. However, even in these areas, moderate amounts of trash/litter refuse were noted scattered on the surface. The western portion of Camp Mabry contained the largest cumulative percentage $(65.5 \%)$ of property not affected by artificial impacts (90 acres). The second largest concentration (22 acres or $16 \%$ ) of relatively undisturbed property was noted on the southern portion of Camp Mabry (see Figure 2). The remaining 18.5\% (25.5 acres) of Camp Mabry's undisturbed property was observed throughout the facility in randomly located patches. 


\section{Chapter 3: Archaeological and Cultural Background}

By Richard S. Jones

\section{Previous Investigations}

A review of records indicates that a total of four Section 106 surveys have been conducted within the confines of Camp Mabry since 1993. All of these prior cultural resource investigations were very limited in scope, combining to cover approximately 50 of Camp Mabry's 375 acres. This survey conducted by CAS represents the largest systematic survey performed within the grounds of Camp Mabry. (Texas Historical Commission Facsimile Memorandum dated 12-21-92, on file at the Archaeology Division of the Texas Historical Commission and with AGTX).

On October 11, 1993, personnel from the cultural resource division of the Adjutant General's Department of Texas (AGTX) surveyed 10 acres of property within the south-central portion of Camp Mabry. The purpose of the survey was to ascertain if cultural resources would be negligibly impacted by construction activities associated with a proposed WWII reenactment. The project was comprised of a pedestrian survey in addition to the excavation of six shovel tests. The investigations resulted in the discovery of no cultural resources and clearance was given for construction activities (Adjutant General's Department Archeological Survey Report Form (dated 10-11-93) on file at the Archaeology Division of the Texas Historical Commission).

On October 11, 1993, AGTX staff archaeologist Alan Wormser discovered prehistoric site 41TV1667 (see Figure 2) while conducting limited surface reconnaissance in the western portion of Camp Mabry. Wormser describes 41TV1667 as being a small prehistoric site (approximately 75 meters in diameter) that collectors have removed artifacts from since 1960 (State of Texas Archeological Site Data Form, on file at the Texas Archeological Research Laboratory, The University of Texas at Austin). He observed one core and three flakes while conducting a non-controlled surface artifact inspection of the site. Subsurface tests (e.g., shovel tests and backhoe trenches) were not conducted.

On June 30, 1994, archaeologists from AGTX-EV were shown prehistoric site 41TV1721 (see Figure 2) by Camp Mabry staff employees, who informed them that numerous artifacts had apparently been removed from this site over the last 10-20 years. The site is located on the far eastern portion of Camp Mabry at the western base of a steep artificial landfill, which covers a large portion of 41TV1721. Due to the landfill's heavy impact on the site, AGTX-EV archaeologists listed the site size as being undetermined. The artifacts collected by Camp Mabry staff employees over the 10-20 year period were shown to AGTX-EV personnel. Middle Archaic, Transitional Archaic, and Late Prehistoric periods of occupation were surmised, based solely on the analysis of diagnostic projectile points noted within the collection (State of Texas Archeological Site 
Data Form, on file at the Texas Archeological Research Laboratory, The University of Texas at Austin). The site was not within the survey area examined by CAS in October 2001, however, personnel from CAS GPS-navigated to 41TV1721 and found the site to be heavily impacted by disturbances from the nearby landfill and road.

In addition to site 41TV1721, AGTX-EV personnel also recorded prehistoric site 41TV1722 on June 30, 1994. 41TV1722 is located in the west-central portion of Camp Mabry (see Figure 2) in a generally flat area, approximately 150 meters west of a maintenance facility fence line (State of Texas Archeological Site Data Form, on file at the Texas Archeological Research Laboratory, The University of Texas at Austin). AGTX-EV describes $41 T V 1722$ as being prehistoric and of undetermined size, and a total of fifteen flakes were collected during initial surface reconnaissance. Subsurface testing (i.e., shovel test, and backhoe trenches) was not conducted on the site at that time.

\section{Cultural Background}

\section{Paleoindian}

According to Collins (1995) the Paleoindian period occurred between 11,5008800 Before Present (B.P.). The Paleoindian period is divided into two sub-periods: the Early and Late Paleoindian. In Central Texas, the Early Paleoindian period began with the retreat of the Wisconsin glaciation episode at the end of the Pleistocene. During this time period large megafauna (e.g., bison antiquus, mastodon, and mammoth) were very common and the Early Paleoindian cultures (e.g., Clovis) widely exploited this abundant resource, employing a big-game hunting subsistence strategy (Willey 1966:37). Clovis and Plainview lance points are the main diagnostic artifacts observed during the Early Paleoindian period. Meltzer and Bever (1995:47-81) have documented the presence of 406 Clovis points in 128 of 254 Texas counties. Due to environmental change and/or over-hunting of megafauna during the Early Paleoindian period, the populations of megafauna declined and eventually became extinct in North America, by approximately 10,000 B.P. (Martin and Klein 1989). The Late Paleoindian period was the time period when native populations shifted the focus of their hunting strategy away from megafauna to other large herbivores such as deer and bison (Collins 1995:382). The native inhabitants who adapted this hunting strategy during the Late Paleoindian period are commonly referred to as the Folsom culture. Angostura, Golandrina-Barber forms, and St. Mary's Hall forms are the primary diagnostic lance points associated with this period, in addition to ultra-thin bifaces, spurred end scrapers, and gravers (Collins and Kerr 1992; Kerr 2000). 


\section{Archaic}

According to Collins (1995) the Archaic period in Central Texas is thought to have lasted approximately 7,500 years, from 8800-1200 or 1300 B.P. Collins (1995) also divides the Archaic into three sub-periods: Early, Middle and Late Archaic.

Early Archaic

Collins (1995) dates the Early Archaic in Central Texas between 8800-6000 B.P. The 4,000 years of mesic (wet and mild) conditions, which characterized the Paleoindian period, showed the first signs of flux during the Early Archaic. Pollen and geologic evidence collected displays an Early Archaic environment that is gradually becoming warm and dry (Collins 1995). By the middle stages of the Early Archaic, severe xeric conditions dominate the environment. This drastic change in climate led to substantial changes in Early Archaic subsistence strategies. The native inhabitants broadened the focus of their subsistence strategy away from the declining bison herds and included such resources as prickly pear, acorns, fruits, rodents, rabbits, and deer (Story 1985:38-39; Weir 1976). Early Corner Notched and Basal Notched dart points were the two projectile points commonly considered to be diagnostic of this period. In addition, Clear Fork Gouges and Guadalupe bifaces (commonly thought to be used for woodworking) are also considered to be associated with the Early Archaic (Collins 1995).

Middle Archaic

Collins (1995) dates the Middle Archaic in Central Texas between 6000-4000 B.P. During the Middle Archaic period, severe and prolonged altithermal (warm and dry) climatic conditions were predominant. The severe altithermal noted within Texas led to numerous important social and subsistence adaptations for the native inhabitants during this time period. The altithermal caused the numerous bison populations, commonly observed in this region during the initial stages of the Early Archaic, to migrate out of Texas into the more mesic climate in the northern Great Plains. With the total loss of bison and severe xeric conditions throughout Texas, native populations migrated into Central Texas where resource-rich environments were fed by natural springs, which rise from the Balcones Escarpment fault zone. This increase in population density in Central Texas is reflected by an increase in the number and size of campsites and burned rock middens (Weir 1976).

Late Archaic

Collins (1995) dates the Late Archaic in Central Texas between 4000-1200 or 1300 B.P. During the Late Archaic, the severe altithermal observed during the Middle Archaic waned and more mesic conditions prevailed (Collins 1995). The return of mesic conditions in Central Texas also saw the return of the large bison populations that left Texas during the Early Archaic. The return of large bison herds brought about a substantial change in the population density and subsistence strategies employed by the native inhabitants in Central Texas during this time period. The mobile hunting and 
gathering subsistence strategy associated with bison-focused hunting replaced the sedentary and holistic food processing lifeways adopted during the Middle Archaic. The noticeable decrease in the accumulation of burned rock middens reflects the change that occurred in subsistence strategies during this time period (Prewitt 1981:80-81). The return of mesic conditions along with the return of bison to Texas also brought about the dispersal of populations away from Central Texas and back into regions once populated during the Late Paleoindian.

\section{Late Prehistoric}

Collins (1995) dates the Late Prehistoric in Central Texas between 1250-260 B.P. The Late Prehistoric period is characterized by significant technological developments (e.g., the bow and arrow, and the introduction of pottery into Central Texas), and an apparent increase in warfare (Black 1989c:32; Story 1985:45-47; Prewitt 1974). Collins (1995) divides the Late Prehistoric into two sub-periods: the Austin and Toyah Phases.

\section{Austin Phase}

The Austin Phase was a time of population decrease (Black 1989c:32). Early expanding stem projectile points (e.g., Scallorn) are common during this time period. Evidence of widespread hostility is substantiated by the fact that a high proportion of arrow-wound fatalities are noticed in burials of this time period (Prewitt 1974).

Toyah Phase

The Toyah Phase is characterized by the introduction of bladelet technology, the appearance of the first ceramics in Central Texas (bone tempered plainware), and the use of lithic technology consisting of Perdiz arrow points, alternately beveled knives, and tear-shaped end scrapers (Black 1989c:32; Huebner 1991:346). Prewitt (1985) and Black (1989c) suggest that this technology encroached from north-central Texas. Hester (1995:444) recognizes this phase as the "best documented Late Prehistoric pattern" throughout south Texas, with dates ranging between ca. 650/700 to 300/350 B.P.

\section{Historic}

The Historic period in Texas is divided into two sub-periods: Protohistoric, and Historic. The following is a very brief and generalized description of the Historic period within the State of Texas. The specific history of the Camp Mabry project area is provided in Chapter 4.

Protohistoric (ca. 470 to 300 B.P.)

The arrival of Spanish explorer Cabeza de Vaca into south and southeast Texas in 1528 marks the beginning of the Protohistoric period. Due to the fact that few written 
records are available for analysis, most of what we know regarding the Protohistoric has been gathered through archaeological means (Hester 1995:449-450). Generally, archaeological sites that date to this period tend to contain both traditional Native American artifacts (e.g., lithic tools) and imported European manufactured goods (glass beads, metal, etc).

Historic (300 B.P. to Present)

The establishment of Catholic Missions by the northward expanding Spanish Colonial Empire marks the arrival of the Historic period in Texas. Unlike the Protohistoric, a great deal of what we know regarding the Historic period is derived from the analysis of the numerous written records produced by early Spanish missionaries.

\section{AD 1690-1726: Early Spanish Entradas Into Travis County}

During the early stages of the Historic period, numerous explorers led Spanish expeditions, which traversed large portions of modern Travis County (McGraw et al. 1991:259-260). Some of the main reasons behind these early Spanish entradas were: (1) the exploration of territory for economic/resource exploitation, (2) the formation of political alliances with the indigenous Native American population, (3) expansion of the Catholic mission system and subsequent conversion of the Native Americans, (4) to halt French Colonial expansion in East Texas, and (5) the expansion of the Spanish Colonial Empire into the New World. The observations Spanish explorers made during these journeys were often recorded in personal diaries. These diaries are both historically and anthropologically important because they provide vivid personal accounts, which describe both the environment and indigenous populations present within Central/South Texas during the late seventeenth and early eighteenth centuries.

Teran-Massanet Expedition. In 1691, Domingo Teran de los Rios (the Spanish governor of Coahuila and Texas) and Father Damian Massanet led a Spanish expedition into central and eastern portions of Texas. The old Indian trading/migration route Teran and Massanet followed during this expedition was subsequently assigned the name 'Camino de los Tejas' and was extensively employed by early Spanish explorers until approximately AD 1800 (McGraw et al. 1991:9). In his personal diary, Father Massanet noted that the Colorado River appeared to function as an Indian border region, where numerous Indian tribes would meet and trade (Baumgartner et al. 1997; Massanet 1932:56). Along the banks of the Colorado River, in modern Travis County, Massanet and Teran encountered five to six Indian tribes originating from Central Texas, Chihuahua, and West Texas (Baumgartner et al. 1997). Massanet described the natural setting of the Colorado River as "... having a great many trees, oaks, cedars, brazil woods, and grapevines" (Massanet 1932:61).

Varono Expedition. In 1693, Salinas Varona (the new Spanish governor of Coahuila and Texas) led a small expedition to East Texas that followed portions of the Camino de los Tejas, which Teran and Massanet traversed in 1691. Like Massanet and Teran, Varona encountered what appeared to be an Indian trading center along the banks of the Colorado 
River. Varona encountered local bands with Tonkawa affiliations (i.e., Sana and Toho), tribes from the Rio Grande (i.e., Simaoma and Mescal), tribes from West Texas and Chihuahua (i.e., Jumano, Saquita, and Simaoma), and Caddoan tribes (i.e., Tejas) from East Texas (Baumgartner et al.1997; McGraw et al. 1991). While traversing portions of what is now Travis County, Varona assigned names to three creeks: the San Fernando, the Arroyo Colorado (Boggy or Walnut Creek), and the Arroyo San Juan de Ortega (McGraw et al. 1998:259).

Espinosa-Olivares-Aquirre Expedition. In 1709, Father Isidro Felix Espinosa, Captain Pedro de Aguirre, and Father Antonio de San Buenaventura y Olivares embarked on an expedition from San Juan Bautista to the Colorado River. The primary reason behind this expedition was to investigate a report they received, which stated that eastern Tejas Indians desired to relocate to the Colorado River and convert to Catholicism (Baumgartner et al. 1997). After the expedition reached the Colorado River, Espinosa unfortunately learned that the Tejas Indians (located three days journey away) held no desires to relocate and convert to Catholicism (McGraw et al. 1991:260; Baumgartner et al. 1997:28). During the expedition, Espinosa took detailed notes describing the vegetation and natural setting of Travis County in antiquity. Like Father Mazzanet in 1691, Espinosa describes the Colorado River as containing numerous luxuriant trees (e.g., pecan, ash-juniper, poplars, elms, and willows (Baumgartner et al. 1997:27).

Ramon-Espinosa Expedition. In 1716, Captain Domingo Ramon and Father Isidro Felix Espinosa led an expedition to East Texas in order to re-establish Spanish missions and curb French Colonial expansion in the area. Following the Camino de los Tejas, Ramon and Espinosa crossed the Colorado River just south of present day Austin (McGraw et al. 1991:9). Espinosa described this area as containing enormous trees, grapevines, hemp, and numerous fish (Baumgartner et al. 1997:30).

Aguayo-Peña Expedition. In 1719, the French successfully invaded East Texas, causing the Spanish to abandon six missions and one presidio. In response, a large Spanish military expedition (led by the Marques de San Miguel de Aguayo) was sent to East Texas in 1721 with the hopes of driving out French Colonial forces, and thus reestablishing Spanish control (Fox 1983:53). The Aguayo expedition followed portions of the Camino de los Tejas, which was previously traversed by Espinosa in 1709 and 1716. After crossing the Colorado River south of modern Austin, Father Juan Antonio de la Peña (Aguayo's diarist) briefly described the environmental setting as containing flat plains, low hills, and numerous bison (McGraw et al. 1998:260). The Aguayo expedition succeeded in recapturing lost territory, and drove the French out of eastern Texas.

Rivera Expedition. In 1726, Brigadier Pedro de Rivera, after receiving orders from the King of Spain to inspect the efficiency of Spanish Colonial presidios, followed portions of the Camino de los Tejas into modern Travis County. Rivera crossed the Colorado River above the mouth of Onion Creek and south of modern Austin. Rivera took very detailed notes on the native peoples he encountered during his journey. He described the groups in proximity to the Colorado (the Aranama) as being peaceful and constantly on the move for game (Baumgartner et al. 1997:35). By examining Rivera's detailed notes, 
the following Indian tribes are known to have occupied the Colorado River during the early eighteenth century: the Aname, Ervipiame, Cujane, Mayeye, Coco, Coapite, Copane, Karankawa, Tacame, and Aranama (Baumgartner et al. 1997:35). Based on the recommendations made by Rivera following this expedition, in July 1730 Presidio de los Tejas (Dolores) was closed. In addition, three east coast missions (San Francisco de los Neches, Nuestra Señora de la Purisima Concepcion de los Hasinai, and San Jose de los Nazonis) were temporarily relocated near Barton Springs/Zilker Park in modern Austin (Baumgartner et al. 1997:35; Travis County 2002). After two months, the three Austin missions were permanently moved to San Antonio and assigned the names: San Francisco de la Espada, Nuestra Señora de la Purísima Concepción, and San Juan Capistrano (Chipman 1992:131).

Spanish Mission Period. Between 1682 and 1793, Franciscan missionaries founded a total of twenty-six missions (occupied for varying lengths of time) within the confines of modern Texas. The primary reasons behind the Spanish implementation of the mission system were to incorporate aboriginal people into the Spanish colonial empire, the Catholic religion, and lastly, the larger Hispanic-Mexican culture (Black 1989c; Spanish Missions 2002). From its inception during the late seventeenth century, the Spanish mission system within the Texas frontier persisted (with varying levels of success) until the late eighteenth century. In 1793, the last Spanish mission (Nuestra Señora del Refugio) was founded in the small town of Refugio. A number of factors lead to the decline and eventual abandonment of the Spanish mission system in Texas; namely (1) the overall decline in Native American recruits to the mission due to high infant mortality rates, (2) European epidemics, (3) hostile pressure from other Indian groups (i.e., Apache and Comanche), (4) demoralization, (5) assimilation into other Indian groups or Spanish/Mexican society, and (6) a Spanish shift toward more liberal free market policies in which individual human rights and capitalism were emphasized over mission communal property (Spanish Missions 2002).

\section{Anglo-American Empresarios}

After Mexico gained independence from Spain in 1821, a number of AngloAmerican citizens from the United States attempted to become Mexican land empresarios in order to establish colonies within the northern Mexican frontier (modern Texas). These early Anglo-American empresarios (e.g., Stephen F. Austin, Samuel May Williams, Green DeWitt) basically established colonies, which funneled large migrations of Anglo settlers to the northern Mexican frontier. In 1821, with the help of Belgian expatriate Baron de Bastrop (who served within the Mexican government), Stephen F. Austin was allowed to establish the first Anglo-American colony within Texas. Austin would become a leading figure in the development of the Texas Republic, and is also generally regarded as the founding father of Anglo-American Texas (Austin 2002). In 1839, the frontier city of Waterloo changed its name to Austin in order to honor the accomplishments and life of Stephen F. Austin. 


\section{Chapter 4: From Plantations to Parade Grounds: A History of the Camp Mabry Vicinity 1830-1913}

by John Leffler

\section{Introduction}

Camp Mabry, the headquarters of the Texas National Guard, covers about 375 acres in northwestern Austin, Texas. It was originally created in 1892 as the first permanent summer encampment ground of the Texas Volunteer Guard. The camp evolved over the next twenty years as the Guard was reorganized and its training activities were increasingly professionalized under federal guidance. By 1913 the original 85 -acre campground had grown to about 400 acres and a number of permanent buildings and training facilities had been completed. Camp Mabry was placed on the National Register of Historic Places in the 1990s largely because of the architectural and historical significance of its development as a military post (Figure 3 ).

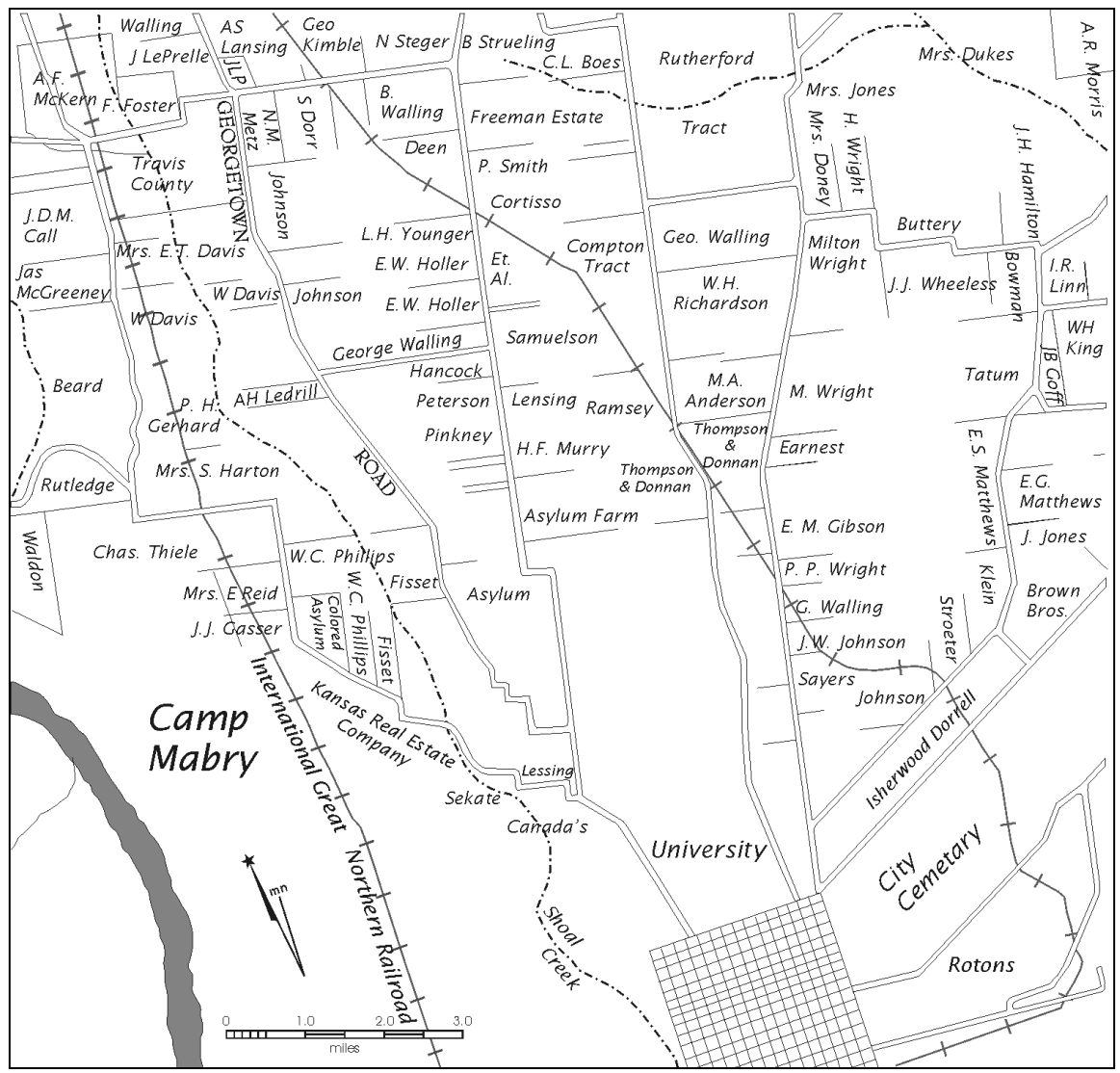

Figure 3. Camp Mabry and the surrounding area in 1902. Source: Road Map of Travis

County, 1898, revised 1902, Center for American History, the University of Texas at Austin. 
Long before the camp was created, however, the land which it now occupies was closely associated with a number of men who, in their times, played significant roles in the economic and political development of Austin, Travis County, and the State of Texas. Former owners of property now occupied by Camp Mabry include Colonel William P. Maben, a plantation owner who lived in the vicinity of what is now Camp Mabry and at one time owned almost half of it; Robert J. Townes, a prominent planter and lawyer who served as Texas Secretary of State during the Civil War and whose plantation, Edgemont, included about half of present-day Camp Mabry (according to one account, remains of some of his slave cabins could still be seen there as late as 1962); James D. Doxey, a local farmer known for his activities in both the Democratic and Greenback Parties of Travis County; George Duncan Hancock, a wealthy Austin merchant and land speculator who served a term in the Texas State Legislature; Lewis Hancock, George Duncan's son, a successful Austin lawyer who was active in many local civic organizations and served a term as the Mayor of Austin; and Charles W. Deison, who moved into the general vicinity of Camp Mabry in the late 1870s and apparently helped to organize or build a church there known as "Deison's Chapel." The lives of these men overlapped and intertwined; most of them knew each other, at least casually, and together their stories reveal something about the evolution of life in Central Texas during the mid-to-late nineteenth century.

\section{Early Land Grants and Settlement in the Vicinity of Camp Mabry}

In the early 1800s the area that is now Travis County was inhabited by the Tonkawa, although the Lipan Apache and Kiowa also passed through. The Comanche had begun raiding in the region in the late 1700 s, and by the 1800 s they competed for control of the region. Indians traveling up and down the Colorado River often passed by Mount Bonnell and the area that is now occupied by Camp Mabry (Barkley 1967:31; Smyrl 1996c).

English-speaking Texans began to move into the region during the early $1830 \mathrm{~s}$. Reuben Hornsby established the first permanent white settlement in what is now Travis County in 1832, and others, including Mathias and Josiah Wilbarger and John Webber, soon followed. In 1835 Joseph Harrell set up a tent on the Colorado River near the present-day site of the Congress Avenue Bridge in Austin; later he built a stockade. When Texas President Mirabeau B. Lamar visited Harrell's settlement in 1837, he was so impressed with the site that he decided to locate the new Republic's capital there. At about that same time Captain Nelson Merrill settled about twelve miles north of the future site of Austin (which was established, along with Travis County, in 1839) and within a few years the village of Merrilltown began to grow near his homestead (Barkley 1967:4-

45; Carpenter 1969; Hazelwood 1996; Smryl 1996b; White 1966). ${ }^{-}$Merrilltown, the first settlement in northern Travis County, would later become the post office for people living in the vicinity of what is now Camp Mabry. 
After the successful conclusion of the Texas Revolution in 1836, the new Republic of Texas began to issue land grants to reward early settlers and veterans of the rebellion, and to encourage immigration. During the late 1830s and the 1840s many thousands of acres in Travis County were claimed and surveyed. These included properties now occupied by Camp Mabry (Figure 4). In January 1838 one Daniel Gilbert was issued a land grant certificate which entitled him to locate, survey, and hold one-third of a league of land because, he, a single man, had moved to Texas in 1835. Before even locating a property to exercise the grant, Gilbert transferred his grant to a Daniel I. Gilbert, possibly his son. Like many grantees in Travis County and other parts of Texas at the time, the Gilberts probably never occupied the Gilbert survey. No Gilberts appear in the Travis County census schedules for 1840 or 1850 , and the property was patented in February 1846 to a Thomas H. Mays (Carpenter 1969; Land Grant File Texas General Land Office (hereafter TGLO); White 1966).

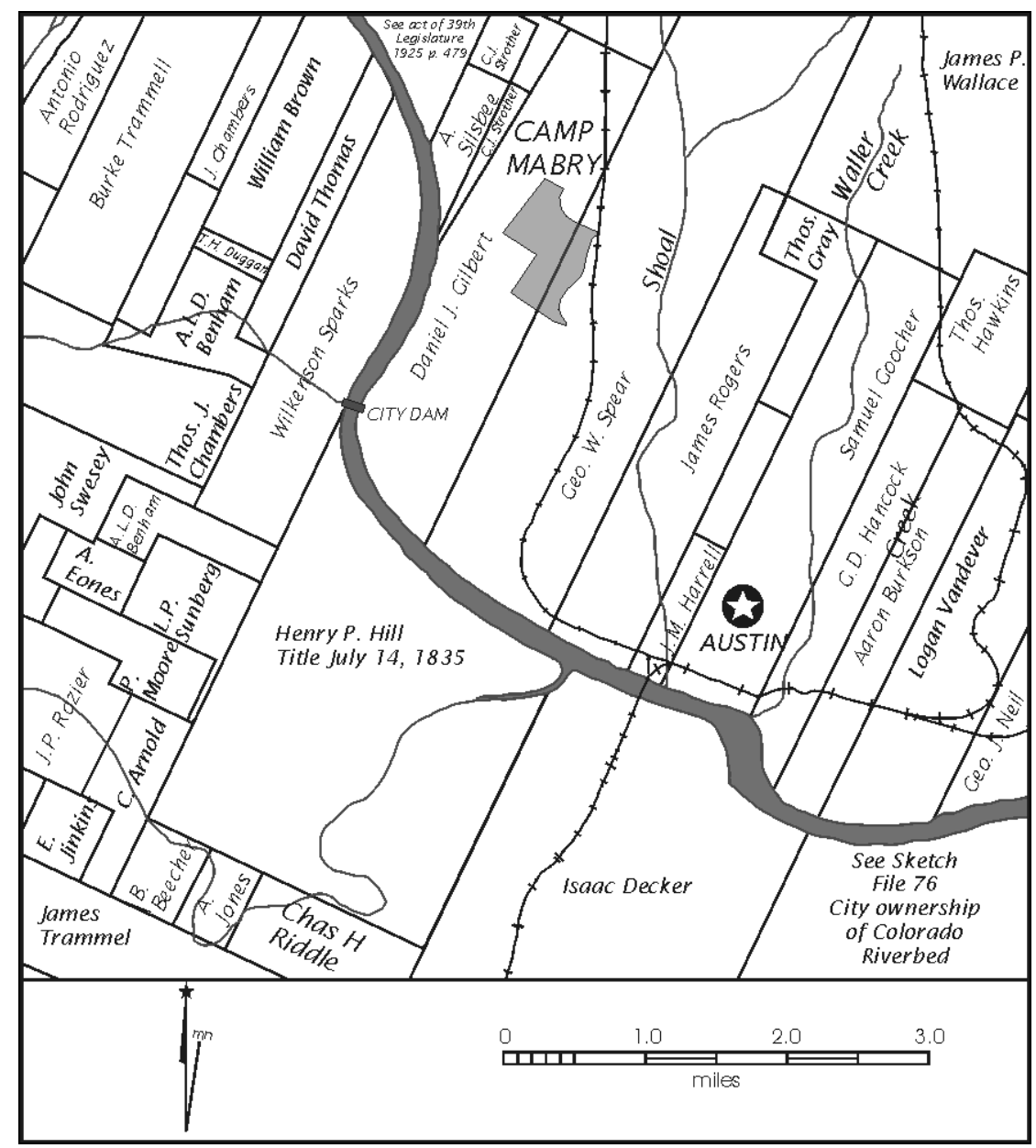

Figure 4. Land Grants in the vicinity of Camp Mabry. Land Grant Map of Travis County, 1936, Texas General Land Office, Austin.

In February 1838 another land grant in the Camp Mabry vicinity was issued to a John Spear (his name was most likely actually spelled "Spier"), who was entitled to a league of land because he had immigrated with his family to Texas in 1835 (see Figure 4). Again, it is most unlikely that John Spier ever saw the property. When he died in 1838 
or early 1839 he was living in Fayette County, and in February 1839 his wife Rebecca and a man named John W. Scallion were appointed to be the administrators of his estate. The land was patented to Rebecca Speir and Scallion in 1841. That same year Scallion paid taxes on the property, but there is no evidence he ever lived there.

Settlement in Austin and the surrounding area was deterred for several years by Indian attacks; by the threat, real and imagined, of another Mexican invasion; and by Governor Sam Houston's decision to move the state capital to Houston in 1842. "In less than three years, if I am elected," Houston reportedly promised during his campaign in 1841, "Austin shall again become the feeding place for buffalo and the hunting ground for red men" (Barkley 1967). Nevertheless, land speculators like Thomas Jefferson Chambers and Josiah Fisk actively bought and sold large parcels of land in the area in anticipation of future settlement.

Immigration into the area began to increase significantly after 1845 , when Texas was annexed by the United States and the state capital was returned to Austin. By 1850 there were 854 people living in Austin, and Travis County's population had grown to 3,138 , including 791 slaves. By the mid-1850s the city was booming and land prices in the area were rising rapidly (Barkley 1967; Humphrey 1996; Smyrl 1996c). Among those who moved into Travis County during the late 1840s and early 1850 s were James D. Doxey, Robert J. Townes and William P. Maben, who each purchased property in the Camp Mabry area during the 1850 s and established homesteads in the immediate vicinity (Figure 5).

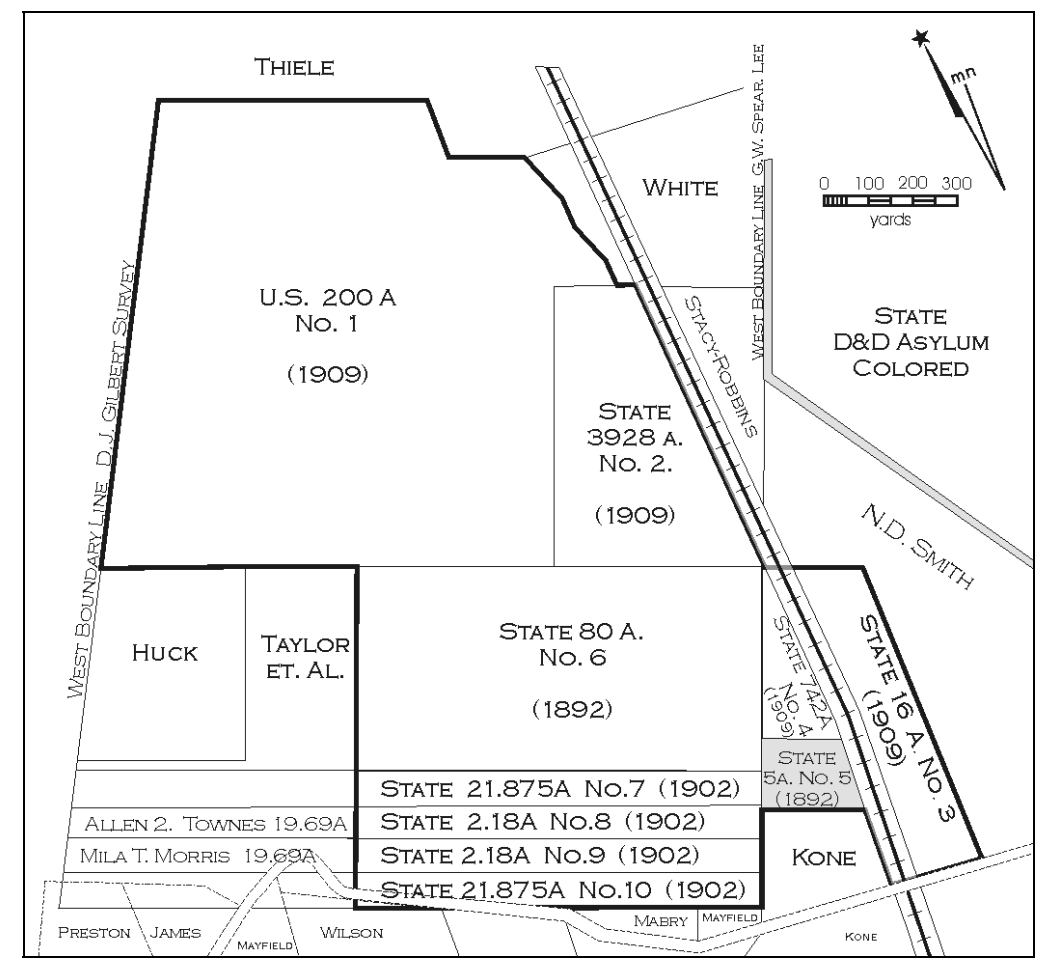

Figure 5. Acquisition Map of Camp Mabry. Source: "Plat of Camp Mabry showing prominent tracts" [1909?], in Camp Mabry historical files, AGTX-EV, Camp Mabry. 
James Dougherty Doxey, originally from Bowling Green Prairie, Missouri, first moved to Austin in 1843 but then returned home, perhaps to take care of a family matter. Not long afterward, however, he returned to Travis County, bringing his sisters and his family's slaves from Missouri with him. On June 5, 1851, when he was about twenty-six years old, he purchased a tract in the Daniel Gilbert survey from Josiah Fisk; the westernmost acreage of his property extended into what is now Camp Mabry (see Tract 5 on Figure 5). By the late 1850s Doxey and his wife, Margaret J. (Adams) Doxey, had built a home (which they called "Heath Hall") on or very near the Camp Mabry portion of their property. Their first son, Thomas Adams Doxey, was born there in 1858 (Hart 1956; Carpenter 1969; Gracy and Genter 1967; Travis County Deed Records (hereafter TCDR) $\mathrm{P}: 50,105: 466-467)$.

Despite the toney name of his home, Doxey was not a member of the elite planter class. The 1860 census describes him as a "farmer" who owned three slaves. By the standards of the time, he seems to have been comfortable though not particularly affluent, and was apparently well-respected by his neighbors. In 1852, he was one of six men who were appointed to be "reviewers" of a new road passing north from Austin to Williamson County, and in later years he was asked to serve as a witness on a number of deeds signed in the vicinity. Later, after the Civil War, Doxey became active in the both the Greenback and Democratic Parties of Travis County. On several occasions he was nominated or elected to attend county party conventions as a delegate from his precinct (Barkley 1967; Gracy and Genter 1967; DDS March 13, 1878, May 21, 1878, June 1, 1878, July 2, 1879, July 9, 1882).

Not much is known about William P. Maben or his wife Mary Ann. Both were originally from Virginia, but had lived in Missouri for at least nine years before moving to Texas with their four children about 1854 . Both were fairly young at the time-he was about thirty-eight years old, she about thirty-five. Maben was described as a "farmer" in the 1860 Census, but since he owned 27 slaves his agricultural activities were likely extensive. The exact location of the Maben's home is not clear, but they did live in the vicinity of present-day Camp Mabry, possibly even within its present borders (Gracy and Genter 1967; TCDR Q:327-328).

At about the same time that Maben was establishing his plantation, Robert $\mathrm{J}$. Townes began to develop his own. Robert J. Townes was born in Virginia about 1806, and probably moved west to Mississippi with his parents, Robert and Effie Townes, sometime thereafter. By 1839 he was living in Brazoria, Texas, where he flourished (Figure 6). In 1852 Townes was elected district judge for Brazoria County and established connections with another local judge, John Hancock. While attending to his duties on the Brazoria circuit, Townes was also investing in Travis County land, and between 1848 and 1854 he bought a number of properties there. In October 1855 Townes and an associate, William P. Maben (sometimes spelled "Mabin"), jointly purchased about 400 acres in the Daniel Gilbert survey from Francis Kelly and Thomas J. Chambers, and then immediately divided the parcel between themselves. Maben's portion of the property included most of the northern half of present-day Camp Mabry, and all of Acquisition Tract 1 (see Figure 5). Townes' share of the property included most of the 
southern half of Camp Mabry, and all of Acquisition Tracts 6,7,8,9, and 10 (see Figure 5)(Friend 1996; Gracy and Genter 1967; TCDR H:511-112; TCDR Q:116-117 TCDR Q:307). ${ }^{-1}$ The purchase was not merely a piece of land speculation; both Maben and Townes had previously purchased other properties nearby, and after 1855 they proceeded to establish their households in the vicinity.

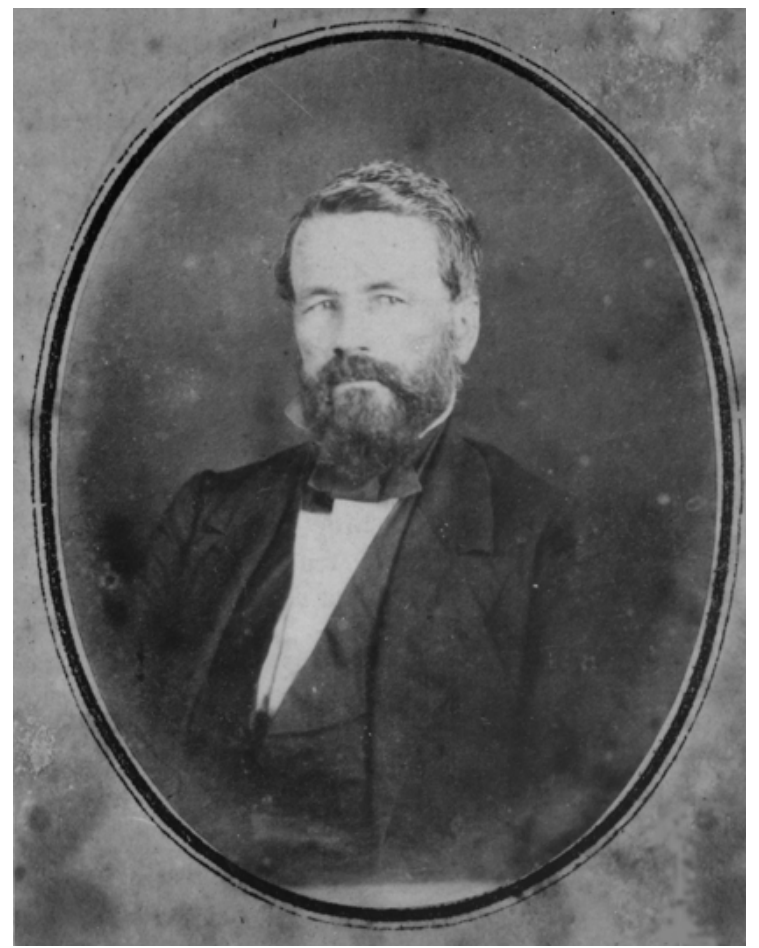

Figure 6. Robert J. Townes as a member of the Texas House of Representatives, circa 1860. Photo courtesy of the Texas State Library and Archives.

In 1855, Townes moved to Travis County with his wife Pattie (Eggleston) Townes and their four children. That same year (through a contract with his mother, Effie Townes of Mississippi) he imported a number of slaves and put them to work building "Edgemont," an elegant 22-room stone mansion overlooking the Colorado near Mount Bonnell. It was completed about 1857 (Figure 7). The slaves also cleared and planted fields, built fences, corrals and stone outbuildings (including five slave quarters) and drilled an artesian well. Townes' plantation (known as "Edgemont Place") soon sprawled across 1,100 acres on both sides of the Colorado River and included the southern half of what is now Camp Mabry (Gracy and Genter 1967; Pohl 1962; SI 1859; TCDR Q:307). In 1967 Mary Starr Barkley described the scene:

Envision [Edgemont] as it was then [in 1860], high on its hill near Mount Bonnell, with cotton planted on both sides of the river (there was no lake at that time) in the low land, with Tarrytown for the yard, and with brick and lime and cement plants working, with sugar cane planted too, and his slave cabins of the field hands (Figure 4-6) which still have remnants standing in the Camp Mabry grounds (Barkley 1967). 


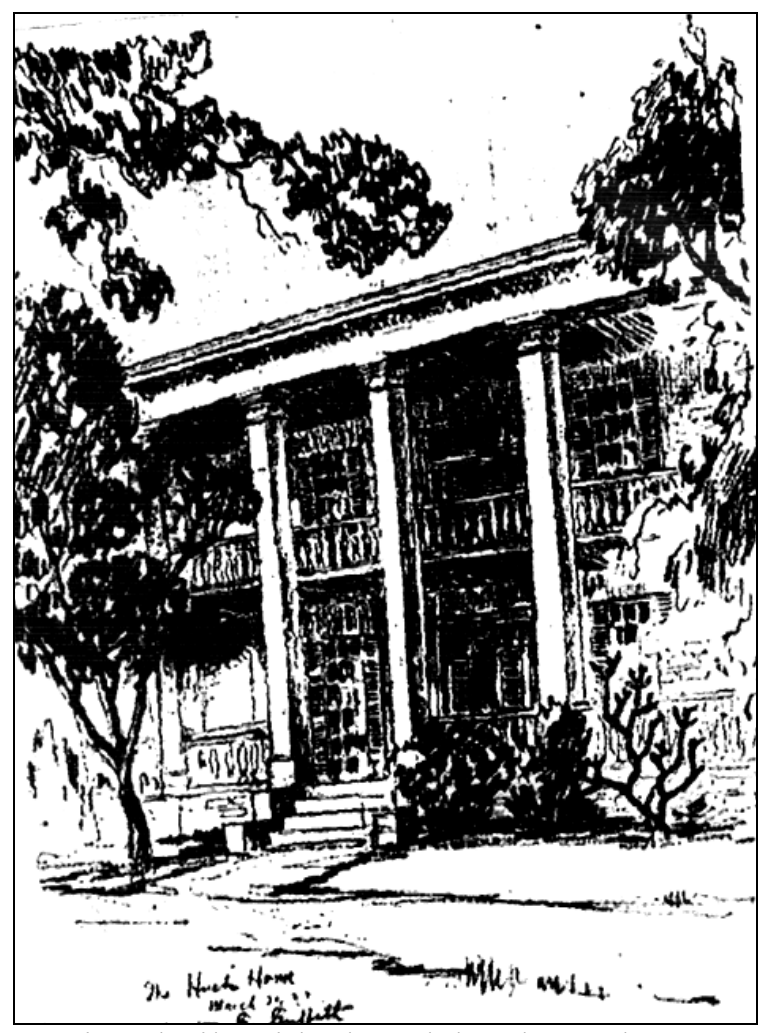

Figure 7. The Edgemont mansion, built with slave labor by Robert J. Townes about 1857. Photo courtesy "Edgemont" AF manuscript file, Austin History Center, Austin Public Library.

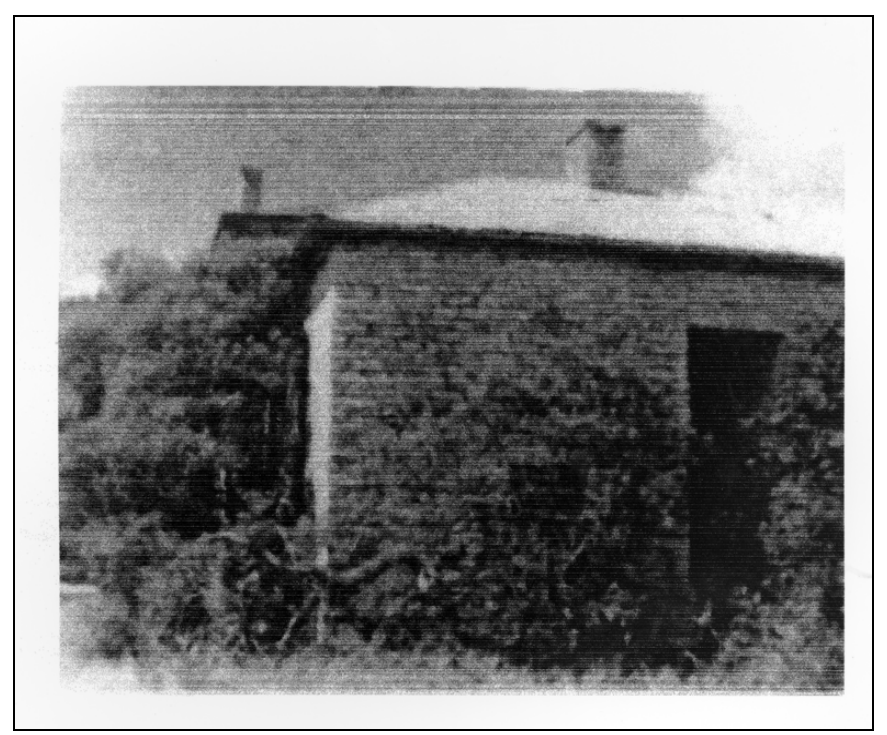

Figure 8. A stone outbuilding near the Edgemont mansion. This was very likely one of the Edgemont Plantation's slave quarters, and probably similar to those built on what is now Camp Mabry. Photo courtesy of Austin History Center, PICH 01748. 
Townes also plunged into local society and politics. According to Bill Pohl, who researched the history of the plantation, Edgemont "became known far and wide in those days for its lavish southern hospitality, and the large dining room, easily accommodating one hundred guests, was often filled." Townes became the president of the Austin Library Association in 1857, and in 1859 was elected to the Texas House of Representatives. In December 1860 he was one of the signers of the address, which called for the convocation of the state's Secession Convention (Friend 1996; Pohl 1962).

By 1860 there were more than fifty people living at the Edgemont plantation. Robert and Pattie's family had grown to include six children: Mila, Pattie, Alfred, Allen, B.L. [Bettie?] and R.A. [Robert?]. Four single adult white females also lived at Edgemont that year: widow Bettie A. Townes (probably Robert Townes' sister-in-law); widow Mrs. Maria Eggleston (very likely Robert Townes' mother-in-law); and two young "spinsters," F.P. and M.S. Eggleston (probably Mrs. Eggleston's daughters). Forty-one slaves toiled on the plantation, including eighteen who belonged to Bettie Townes (Gracy and Genter 1967).

In the immediate vicinity of the Edgemont mansion the 1860 census also shows four white working-class households headed by men who may have been employed by the plantation's lime and brick plants. Among these was Charles W. Deison (or "Dyson"), whose occupation was listed as "Limemaker." Charles (born in Virginia about 1819) and his wife Eliza (born in North Carolina about 1828) moved from Arkansas to Texas about 1854 with their four children-Sarah Evelyn, Mary Marcie, William and R. [Rachel?]. Deison owned no land, but he did raise some crops, probably to help feed his family, on land he may have leased from Townes or Maben (Gracy and Genter 1967; TCDR 239:82$83)$.

\section{The Camp Mabry Vicinity, 1865-1892}

The Civil War and its aftermath coincided with the demise of the Townes and Maben plantations and led to a number of changes in the landholding and land use patterns in the Camp Mabry area. Though the war marked the high point of Robert Townes' political career-he served as the Secretary of State of Texas from September 1862 to May 1865-the death of his wife Pattie on August 24, 1864 must have been a blow to him, and the Confederacy fell just a few months later. Colonel William Maben (as he was known by the 1860s) also experienced personal grief during the war when his oldest son died in 1862 while serving in the Confederate army. Both Townes and Maben suffered severe financial reverses because of the South's defeat: emancipation meant the

loss of their many slaves, and land values in Travis County plummeted in the aftermath of the war. In late $1865 \mathrm{Col}$. Maben sold all or almost all of his property in the area. Robert Townes died in early October that year. The Edgemont home was left empty for many years, and the plantation's properties fell into neglect and disrepair (Brown n.d.; Civil Court Records, TCDC; Friend 1996, Smyrl 1996c). 
While it took years for Travis County to recover from the economic turmoil that shook its economy in the years just after the Civil War, by the 1870s the region was experiencing a boom of sorts, powered partly by new railroads that connected area farmers to national markets. The Texas Central Railway built into Austin in 1871, and in 1876 the International and Great Northern Railroad completed construction from Rockdale into Austin; its tracks ran directly east of what is now Camp Mabry (see Figures 3 and 9). Meanwhile thousands of people, many of them farmers, moved into the area; the county's population more than doubled during the 1870s, and more than 27,000 people lived there by 1880 (Smyrl 1996c).

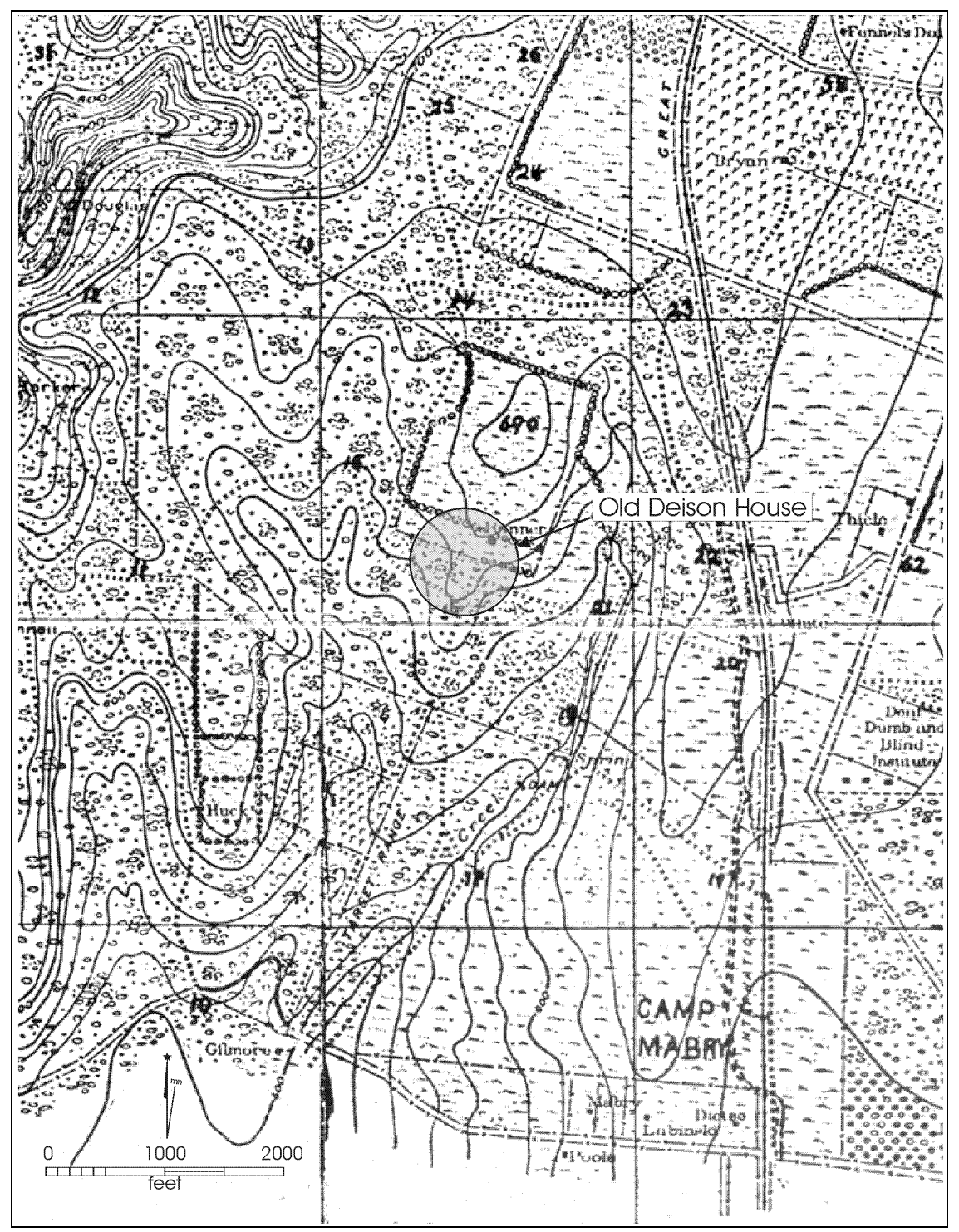

Figure 9. Map of Camp Mabry and the immediate vicinity in 1906. Sources: U.S. Department of War, Army Corps of Engineers. Map of Maneuver Grounds, Camp Mabry, Texas, 1906, in Camp Mabry Historical Files, AGTX-EV and "Camp Mabry Reservation Near Austin," Map drawn by A. Drowt, surveyor, 1913, revised by Office Engineer, $8^{\text {th }}$ Corps U.S. Army, in "Camp Mabry" vertical file, Austin History Center. Figure 9 overlays the location of the Deison place shown in 1913 on the 1906 map cited above. 
While many properties were divided and developed in Travis County during the 1870 s and 1880s, large portions of the area that is now Camp Mabry remained intact, more or less, during this period for two main reasons. George Duncan Hancock (Figure 10 ), who came to own a great deal of property in that general area, seems to have been more interested in accumulating property than in selling it. Meanwhile, Robert Townes' old holdings in the area remained for many years in legal limbo, intact but deteriorating and empty.

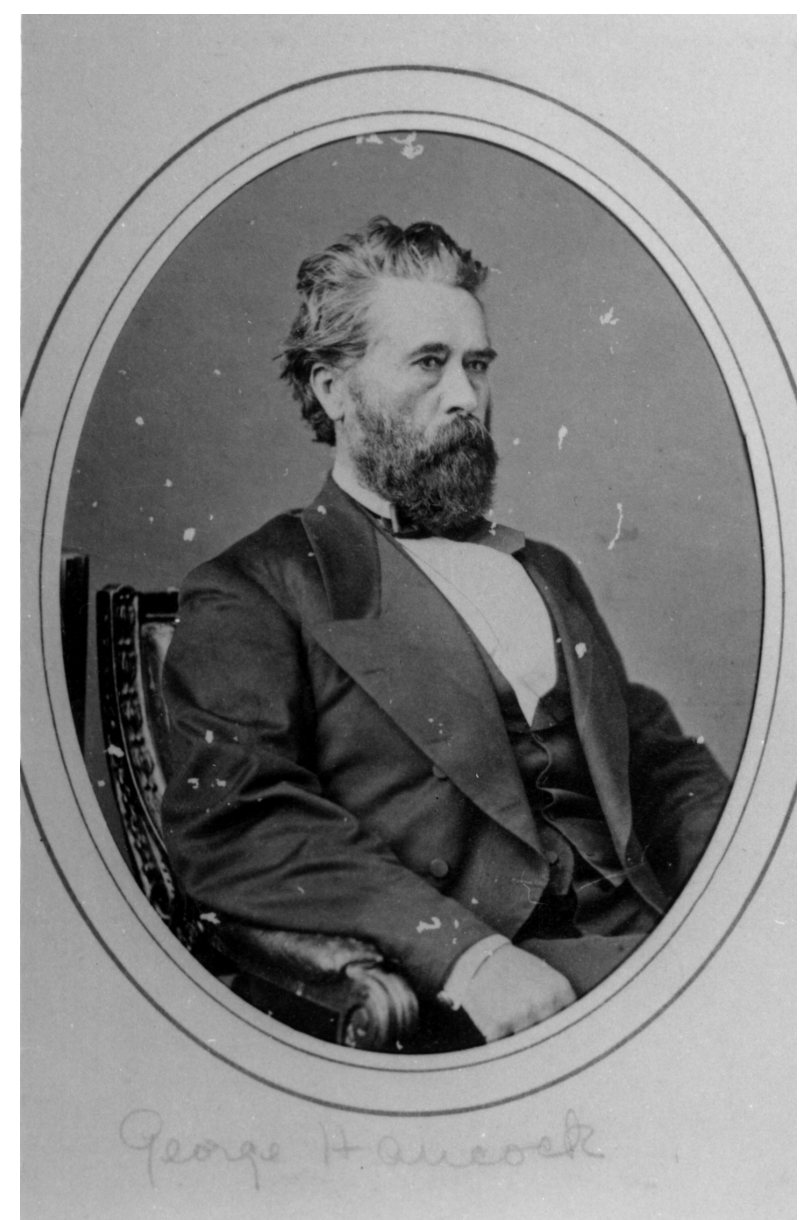

Figure 10. George Duncan Hancock. Photo courtesy of Austin History Center, PICB 03462.

George Duncan Hancock was born in 1809 in Tennessee and moved with his parents, John and Sarah Hancock, to Alabama in 1819. In 1835 he went to Texas, and in 1836 served as a private at the Battle of San Jacinto. By 1840 Hancock was living in Bastrop County and owned over 5,000 acres of land there. In 1845 he moved to Austin, opened a store downtown, and began to invest in Travis County real estate; by 1850 he had accumulated more than $\$ 40,000$ in personal assets. By the mid-1850s Hancock ranked among Austin's most prominent citizens, and his already extensive landholdings continued to grow. He and his wife Louisa had a son, Lewis, in 1856. During the Civil War, Hancock, a strong Unionist, maintained a low profile. In 1861 he closed his business for the duration of the war. Nevertheless, he continued to buy properties, and 
when the war ended in April 1865 he was financially poised to expand his landholdings yet further. He was also ready to become actively involved in politics and society. He was elected to the Texas House of Representatives in 1866, and in later years served on several state and local committees and boards (Cutrer 1996; Barkley1967). ${ }^{1}$ As noted earlier, Colonel William Maben liquidated his plantation lands soon after the end of the Civil War. In August 1865 he sold three tracts to Robert Townes. Then, on December 7, he transferred three more tracts, totaling about 285 acres, to George Duncan Hancock for $\$ 16,000$ (about $\$ 56$ per acre). One of these properties, located in the Gilbert survey, was the 200-acre tract (Acquisition Tract 1; see Figure 5) that had been Maben's share of the 400 -acre tract that he and Townes had purchased jointly in 1855. With this sale Maben seems to have disposed of the last of his holdings in the Camp Mabry vicinity. George Hancock also bought a number of other tracts north of Austin during the 1860s and 1870s, including a 71.5-acre tract in the George Spears survey, part of which, eventually, would be acquired by the State as Acquisition Tract 4 (Pohl 1962; TCDR Q:328-329; TCDR W:644-646).

It is not clear who, if anyone, lived on Maben's old 200-acre tract from 1865 to 1885. George Hancock certainly did not, but the property remained in his real estate portfolio for almost fifteen years; after he died in 1879, it passed into the hands of his son. Lewis Hancock was, according to one account, the first Texan to attend Harvard Law School, and by the time his father died he was already beginning to establish a successful legal practice in Austin (Figure 11). Like his father, Lewis actively participated in local civic and political affairs, and during the late nineteenth and early twentieth centuries he was one of Austin's most prominent citizens. Over the course of his career he established the Hancock Opera House, and was president of the Capital Fair Assgciation and the Austin Country Club; he served as Mayor of Austin from 1895 to 1897. ${ }^{-}$Lewis Hancock held onto the Camp Mabry properties he inherited from his father for about six years, but there is no evidence that he ever attempted to develop them.

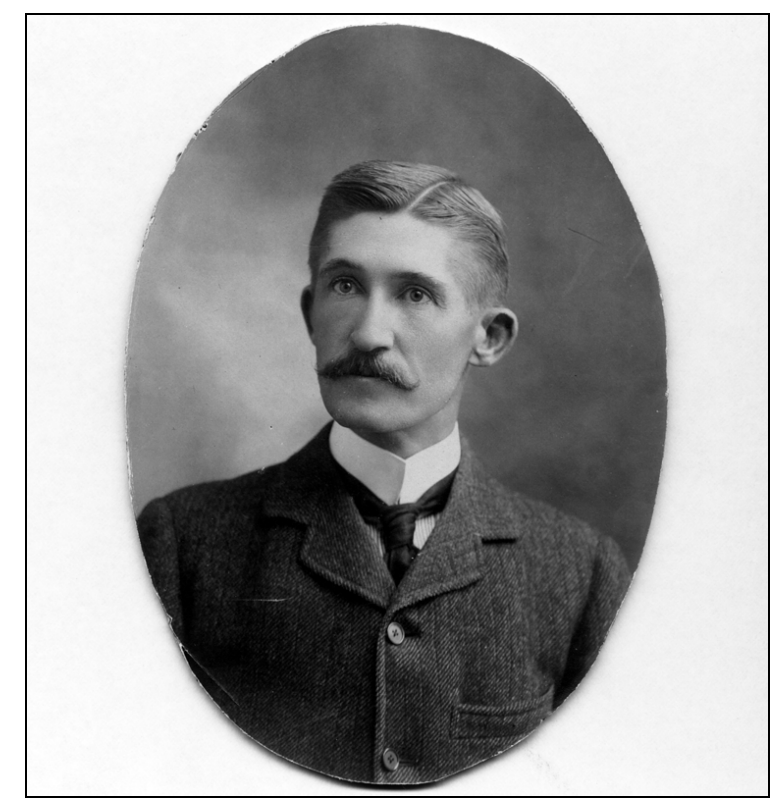

Figure 11. Lewis Hancock. Photo courtesy of Austin History Center, PICB 03497. 
In the months before he died in October 1865, Robert Townes seems to have known his death was imminent, and he took various steps to set his affairs in order and to ensure that his seven children would be properly cared for. (It will be recalled that Robert's wife Pattie had died the year before, so Townes knew his young children would be orphaned after his passing.) In August 1865 William Maben put to paper his previously verbal agreement with Townes to split the property that they had bought together in 1855. A few weeks later, in September, Townes executed a deed of trust that placed all his property, including the Edgemont Plantation, in the hands of Evard T. Eggleston, his brother-in-law, with the understanding that Eggleston would serve as the guardian of his children and administer Townes' estate on their behalf. And just before he died, he wrote a will that named Eggleston as his children's legal guardian (Case File 3738 Civil Case Files, TCDC; TCDR Q: 116-117, 308).

After Townes died, however, Eggleston for whatever reasons, apparently neglected his responsibilities as the children's guardian, and allowed the Edgemont properties (including those in present-day Camp Mabry) to fall into poor condition. A suit brought in Travis County District Court against Eggleston in 1873 by Mila (Townes) Morris, Townes' oldest daughter, and her husband J.B. Morris on behalf of Townes' seven children contended:

That on the seventh of October 1865 the said R. J. Townes died having appointed by will the defendant E. T. Eggleston guardian of the persons and estate of each of said children. That the said Eggleston has never qualified as such and has not for a number of years, if any, discharged in any manner his duties to such children as guardian, nor has he in any manner for a number of years, if ever, exercised any control whatever over said property as a trustee but has with the utmost indifference allowed said property to take care of itself and permitted the minor children to live as best they could....no provisions have been made by the said Eggleston, and the minors Cobbs, Allen and Evard...have no means for their education or maintenance.

The suit further alleged that Edgemont's "very valuable improvements" were "deteriorating daily" and that "the property as now situated is non-productive ... said property and the buildings are unprotected \& suffering daily from trespassers \& depredations." The suit asked for the sale of the Edgemont mansion and the improvements on the fifty acres surrounding it, and "prayed" that the proceeds of the sale and the remainder of the property be divided among the surviving children, "share and share alike" (Civil Case Files, TCDC).

Through his lawyer Eggleston replied that he did not dispute the "facts of the case" as presented by Morris, except to say that he had never been obligated to serve as the children's guardian and therefore had not neglected any duties. In June 1874 the Court ruled in favor of the plaintiffs. The old mansion was to be sold, with the proceeds of the sale and the rest of the land divided amongst the seven children. As part of the settlement, the Townes land in what is now Camp Mabry was divided between Mila (Townes) 
Morris, who was awarded the northern part of the old 200-acre tract (Acquisition Tract 6, see Figure 5) and Evard T. Townes, who was awarded the southern part (Acquisition Tracts 7,8, 9, and 10) (AA February 29, 1956; AS November 16, 1953, 29 February, 1956; Pohl 1962).

Both of these properties apparently remained unoccupied for the next twenty years. By 1892, when the Texas National Guard acquired Mila's tract, it had reportedly reverted to a "wild" state. Evard Townes was only about twelve years old when his share of the property was awarded to him, and it is unlikely he ever occupied or improved it. In 1881, when he was nineteen years old, Evard left Texas and was never heard from again. In the early 1890s, people interested in acquiring the property to enlarge Camp Mabry were not even sure who owned it (ADS July 17, 1892; Case Files, TCDC; Heligbrodt 1943).

In January 1885, while the Townes lands still stood unused, Lewis Hancock sold the 253 acres in the Gilbert survey that he had inherited from his father to Charles W. Deison. The property sold included the 200-acre tract once owned by Maben (Acquisition Tract 1) as well as an additional 59 acres in the Gilbert survey directly to the east (later, 39 acres which would later become Acquisition Tract 2; see Figure 5). Deison, the new owner of the old plantation land, was the same man who, twenty-five years before, had been working as a limemaker near the Edgemont plantation (Moody 1991; TCDR $129: 347 ; 234: 554 ; 239: 82-83)$.

Charles and Eliza Deison had moved away from their home near Edgemont during the 1860s and in 1868 were living a few miles east, near the present-day intersection of $35^{\text {th }}$ and Guadalupe Streets, when their son Clint was born. By the $1870 \mathrm{~s}$ Charles Deison had managed to buy 35 acres of land in the Spears survey and settled there, apparently farming and raising horses and mules for a living. The "Deison Settlement," as his place was known, included a "suburban church" called "Deison's Chapel." In 1878 the [Austin] Daily Democratic Statesman carried two announcements of services held there and baptisms administered in the "living waters" a hundred yards from his home ( $A S$ July 15, 1953; DDS March 9, 1878, July 28, 1878; April 22, 1879; Travis County Tax Assessor's Land Register).

In 1885, when the Deisons moved onto the 253 acres they bought from Lewis Hancock, Charles Deison was about 66 years old, his wife Eliza about 57. The site of their home in the northern half of what is now Camp Mabry can be seen, labeled "Old Deison Place," on a 1912 map of the Camp Mabry area; the location of their field and the stone wall that surrounded it are also marked (see Figure 9). One of the Deison's sons, Clint (who was living with his mother in 1900, probably in the "Old Deison Place"), became well known in Austin during the late nineteenth century for his mule teams. In the 1880s, he helped to pull up the tracks used by the city's old mule-powered trolleysusing mules to do it ( $A A$ July 15, 1953). The Deisons were still living "near Camp Mabry" in 1902 (Heligbrodt 1943). 
By the late 1880 s the Deisons were quite likely the only people living on what is now Camp Mabry. The old Townes and Maben plantations had long since disappeared, and most of Townes' children had scattered across Texas and the nation. Farmer James Doxey, who had settled in the Camp Mabry area during the 1850s, still owned property there in the mid-1880s (including Acquisition Tract 5). He had been active in the Merrilltown precinct of the Travis County Democratic Party in the early 1880s, and his family may still have been living in the area by 1885, but in a 1956 interview his grandson intimated that they had probably moved elsewhere by that time, and his property was in poor condition by 1892 . In the late 1880 s Charles Deison and his family were living on their 253-acre property (Acquisition Tracts 1 and 2), 200 acres of which had once been owned by Maben; but Deison was about 66 years old by 1885, and he probably died before 1890. Lewis Hancock and his mother Louisa still owned one piece of property (Acquisition Tract 4), which they had inherited from George Hancock, but they had been selling off their land in the area for several years. Within a few more years, in 1890, they would sell that parcel to a group of out-of-state investors.

The Camp Mabry vicinity was still considered to be far outside the City of Austin proper in the late $1880 \mathrm{~s}$, but it was gradually being drawn closer to the city's orbit. The International \& Great Northern Railroad had built through the area in 1876, and in 1887 the state built its Asylum for Deaf, Dumb and Blind Colored Youths just east of the future Texas Volunteer Guard campsite, on the other side of the I \& G N's tracks (see Figures 3, 4, 5, and 12). When in the early 1890s Austin boosters began to look for a local site for the annual encampment of the Texas Volunteer Guard, it is not surprising that the Camp Mabry vicinity drew their attention. It included hundreds of acres of unoccupied well-drained land, owned by likely willing sellers; and it was serviced by a major railroad and located only about three miles from the center of Austin.

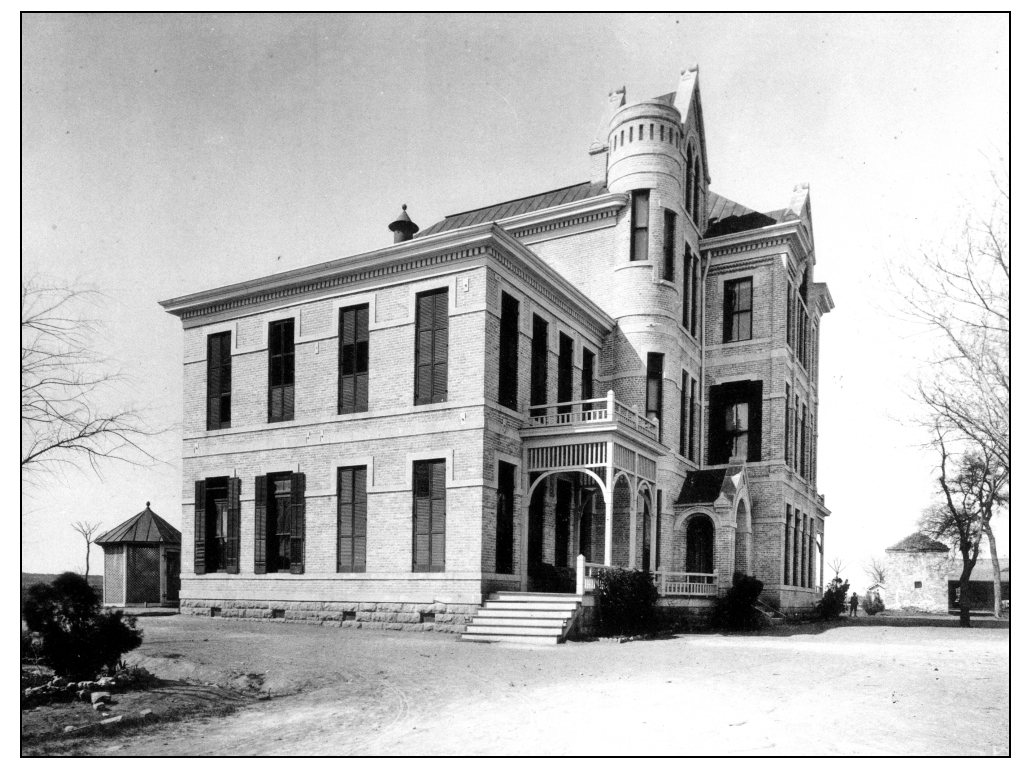

Figure 12. The Negro Deaf and Dumb Asylum, established 1887. From Artwork of Austin (1894). Photo courtesy of Austin History Center, PICA 02971. 


\section{The Creation and Expansion of Camp Mabry, 1892-1913.}

In the late nineteenth century state militia organizations in the United States were an important component of the nation's defense strategy, but the federal government contributed little to support them. In 1890, after Congress appropriated only $\$ 400,000$ for the militia in every state in the Union combined, the Texas Adjutant General complained about the "meager and miserly ways in which appropriations have always been made for these purposes"([Texas. Office of the Adjutant General] Report of the Adjutant General of the State of Texas for 1889-1890 Austin 1890:5).

Most state legislatures, particularly in the South, were at least equally reluctant to support their militia organizations. Texas was no exception. Companies in the Texas Volunteer Guard were usually expected to raise their own monies to acquire and maintain their armories and to uniform and equip themselves. In 1889, members of the state's Volunteer Guard units spent more than $\$ 20,000$ of their own money for these purposes, and had already invested tens of thousands of dollars more in their armories and equipment. As late as 1897, the Texas legislature appropriated only $\$ 5,000$ to train and equip its militia companies-or about $\$ 1.70$ for each of its Guardsmen that year. As a result, the Texas Volunteer Guard companies were often unprofessionally led, poorly equipped and received only rudimentary military training. As the Texas Adjutant General noted in 1890, many Guardsmen were "almost totally ignorant of anything military beyond company movements"(Leffler 1991; [Texas. Office of the Adjutant General] Report of the Adjutant General of the State of Texas for 1889-1890 Austin 1890:34-37).

Texas officials responsible for organizing and training the Volunteer Guard often complained about their limited funding but worked hard to raise funds through public subscriptions and donations and continued their attempts to upgrade the Volunteer Guard's equipment and professionalism. In 1890, in San Antonio, the Guard held its first summer "Camp of Instruction" -a convocation meant to focus on training and in which, the Adjutant General hoped, the State "could have real control and discard most of the objectionable money-making schemes which commonly accompany prize drills" ([Texas. Office of the Adjutant General] Report of the Adjutant General of the State of Texas for 1889-1890 Austin 1890:4).

Though a U.S. Army officer assigned to inspect the Volunteer Guard at the San Antonio encampment was critical of the Guard's performance, the Adjutant General believed the encampment had served its purpose. Many Volunteer Guardsmen had received their first taste of "real instruction in the many duties of military life," and those who organized the encampment had learned a number of valuable lessons that would prove useful at future gatherings. He was not pleased, however, that a number of companies had declined to attend: "The sole and single object of camps of instruction, in a military sense, is to learn and to practice all that can be taught about a soldier's duties in the time devoted to this purpose. This is a duty he owes the State, his associates, and 
himself ([Texas. Office of the Adjutant General] Report of the Adjutant General of the State of Texas for 1889-1890 Austin 1890:12-16).

In 1891, backed by a new state law and attempting to instill more military discipline into its companies, the Volunteer Guard held a compulsory summer Camp of Instruction in Hyde Park, just north of Austin. Five companies were expelled from the Guard for failing to appear as ordered: "I think such action by this Department will have a salutary effect on all future Encampments," commented W. H. Mabry, the new Adjutant General (Figure 13). Altogether he judged the Austin Encampment a great success: "The troops seem to have been pleased with its management, and the tour of duty was marked by much improvement in all the soldierly duties incident thereto" ([Texas. Office of the Adjutant General] Report of the Adjutant General of the Stateof Texas for 1890-1891 Austin:1891:4).

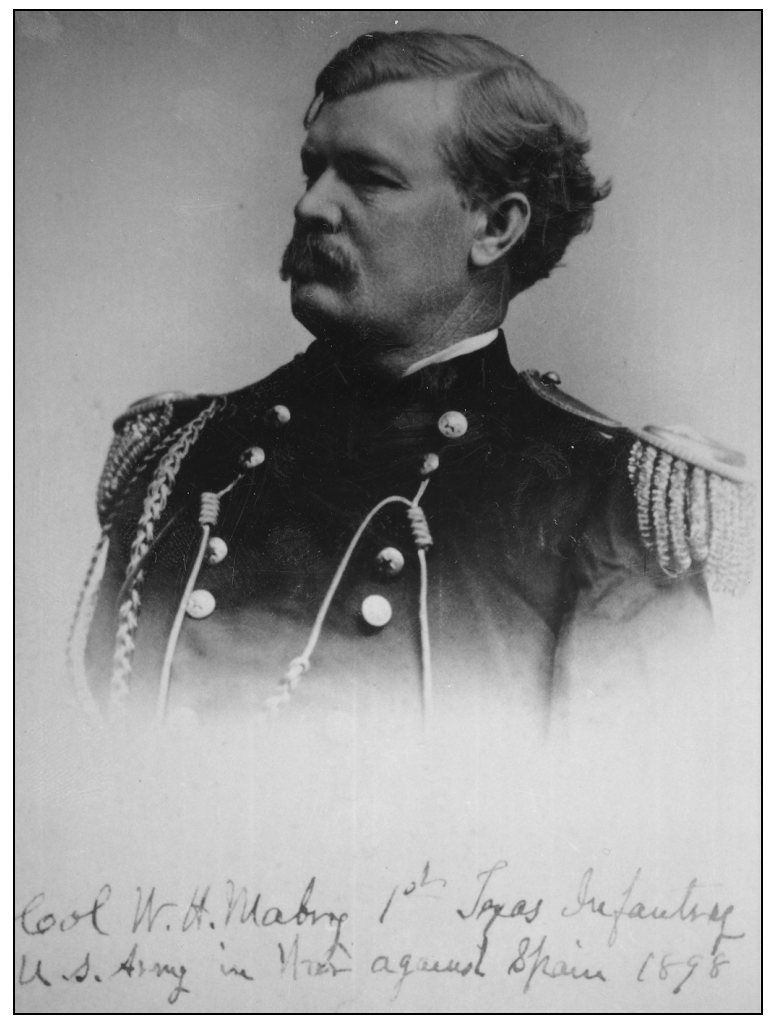

Figure 13. W.H. Mabry, Adjutant General of Texas, 1891-1898, here seen as the commanding officer of the First Texas Volunteer Infantry during the Spanish-American War, 1898. Photo in Camp Mabry historical files, AGTX-EV, Camp Mabry.

As he moved to instill more professional military discipline in the Volunteer Guard, Mabry also worked to improve its training facilities by establishing a permanent summer encampment site. In 1891 Mabry helped to assemble a group of "public-minded and patriotic" citizens in Austin, which came to be known as the Citizens Encampment Committee, to locate a suitable site for a permanent summer training camp and to raise subscriptions to pay for it. Several Texas cities made "princely offers" in their bids for the camp, but Mabry chose Austin, he later explained, because 
Everything else being equal, it needs no argument to prove that Austin is the proper place for the location of the permanent encampment. It is the Capital City, centrally located, and the domicile and headquarters of the Volunteer Guard, while the name is rich in tradition of valor and heroism... Believing in the sincerity and the good faith of the pledges made by a few public spirited citizens of Austin, coupled with the beautiful and eligible site offered, the Capital City won the prize ([Texas. Office of the Adjutant General] Report of the Adjutant General of the State of Texas for 1891-1892 Austin 1892:5-6).

In 1892 the Encampment Committee arranged to purchase two properties through its agent and trustee John Peeler, a prominent Austin attorney. The first (Acquisition Tract 6; see Figure 5) was the 80-acre tract that had been awarded to Mila (Townes) Morris during the 1874 lawsuit against Eggleston over the old Townes plantation lands. The second (Acquisition Tract 5) was a 5-acre tract purchased by the Encampment Committee from James Doxey, who apparently had moved away from the vicinity by that time (TCDR 105:466-67). Even before the sales had been finalized, a work crew toiled to prepare the site for the 1892 encampment (Figure 14). As the Austin Daily Statesman reported in July,

The site purchased was in its wild condition, covered with timber, entirely unimproved and very rocky... Clearing the grounds, cutting down the undergrowth and thinning out the trees employed a force of about twenty men for months. Blasting the rocks, picking up the stones and hauling them off and filling up the holes on the parade ground made by the displaced rocks required a large force. Digging out the bathing pool and building the brick dam came next .... Water connections, purchasing one and a half miles of pipe, and laying it. . . to the camp was probably the most important duty of the committee. . . . [and it was decided] to connect with the city water works as being the surest means of supplying the camp with water beyond doubt (ADS July 17, 1892).

The Encampment Committee also contracted to have a grandstand, mess sheds and other structures built at the camp. About a fifth of the new improvements were constructed on land south of the Camp, encroaching on property owned by Evard Townes, who had disappeared without a trace more than ten years earlier. Those responsible later contended that they had planned to purchase the property but could not find the identity of the owner. Buying the properties for the camp and constructing the improvements cost the Committee tens of thousands of dollars-more, in fact, than it had been able to raise through public subscription, and the problem was compounded when some of the subscribers turned out to be unable or unwilling to pay up. In July General Mabry agreed to loan the Committee almost $\$ 2,000$ from proceeds of the sale of privileges at the 1892 Annual Encampment, and a generous personal loan from Captain J. M. Day, a wealthy cattleman, settled the Committee's immediate obligations. The new facility was named "Camp Mabry" by a vote of the members of the companies attending 
the 1892 Encampment (Heligbrodt 1943; ([Texas. Office of the Adjutant General] Report of the Adjutant General of the State of Texas for 1891-1892 Austin 1892:6; Tyler 1996).

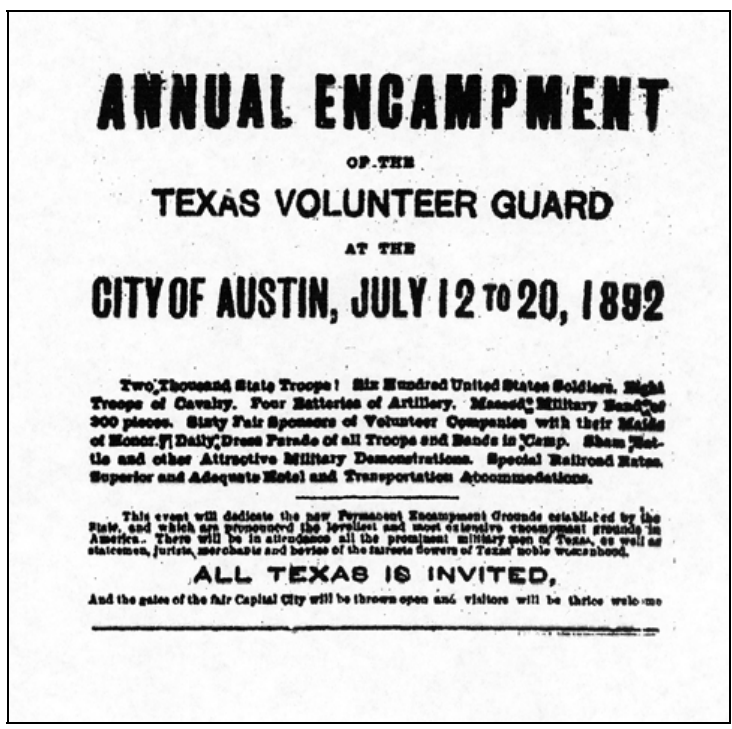

Figure 14. An advertisement for the Texas Volunteer Guard's 1892 Annual Encampment, published in the Austin Daily Statesman, July 12, 1892.

In 1892 and for many years afterward the Volunteer Guard's summer encampments at Camp Mabry were among the great social occasions of the year in Central Texas (Figures 15, 16, and 17). Many thousands of people from all over the state would journey to Austin in July to watch the "sham battles" enacted there for training purposes and to raise money to help pay for the camp and its expansion. John Peeler and other prominent Austin citizens organized lavish balls to entertain the dashing young militiamen and their escorts. "[W]ithout indulging in any undue boasting," the Austin Statesman proclaimed in 1894," the Statesman this morning assures the visiting militia that the ball that will be given in their honor next Monday night will be the grandest society event yet arranged and executed in the history of Texas." Over 10,000 people gathered at Camp Mabry in 1894 to meet the Guardsmen and to watch the "sham battle" on July 17: "They came from every direction; on the [electric trolley] cars, in wagons, buggies, carriages, on foot, any way just so they got there," the paper reported the next day, "and they all enjoyed it hugely." In 1905, the Statesman predicted that eight or ten thousand people from North Texas alone would travel to Austin for the sham battle. The campgrounds were also used for other community events. On June 19, 1895, one element of Travis County's African-American population traveled to Camp Mabry to celebrate Juneteenth (Emancipation Day)(ADS July 14, 1894; $A D S$ July 18, 1894; $A D S$ June 19, 1895; AS August 23, 1905). 


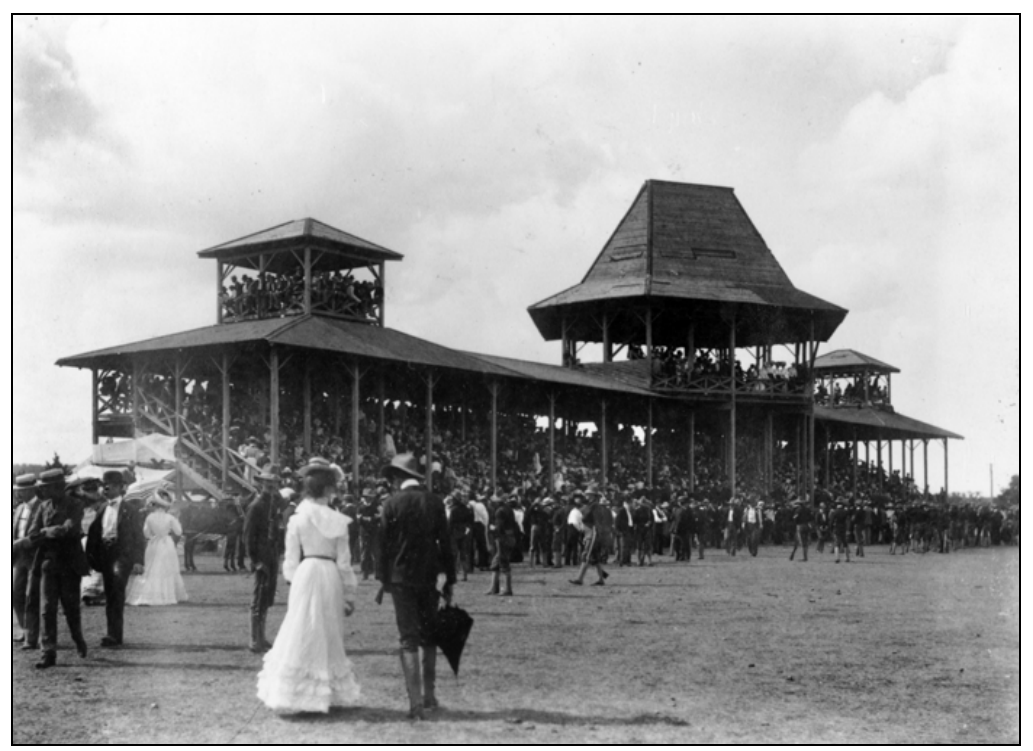

Figure 15. The Camp Mabry grandstand, built in 1892. It burned down, probably the victim of arson, in 1902. Photo courtesy of Austin History Center.

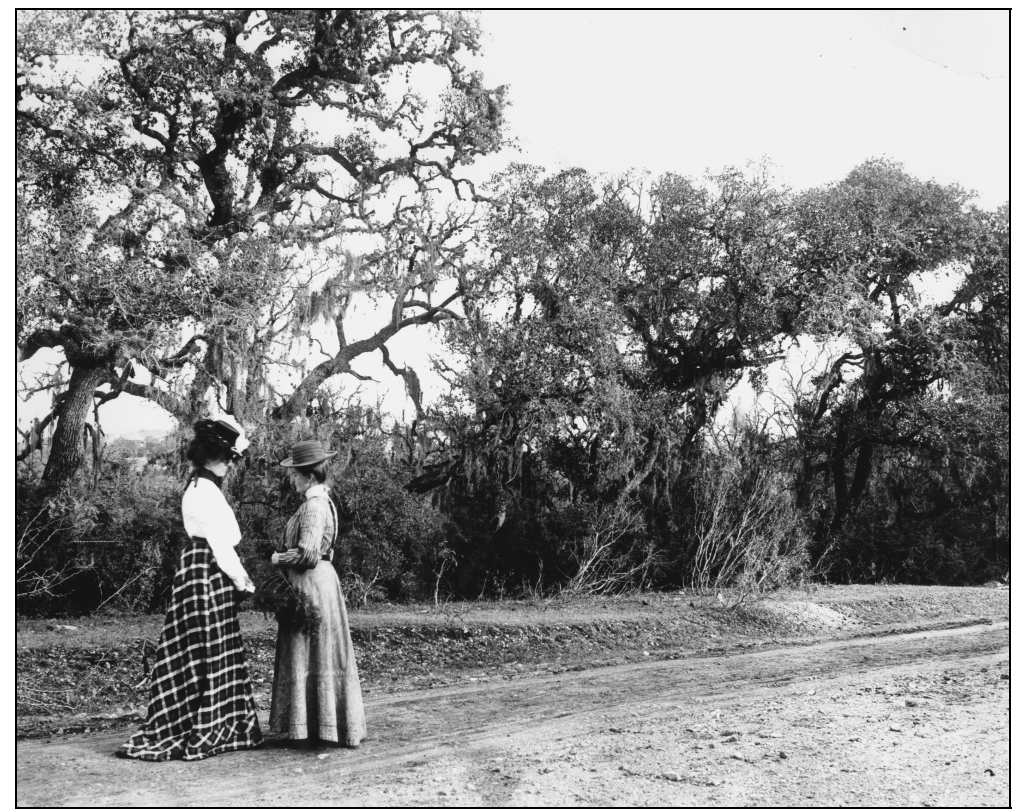

Figure 16. Women visiting Camp Mabry, circa 1890s. Notice dense undergrowth and dirt road. Photo courtesy Austin History Center, PICA 02972. 


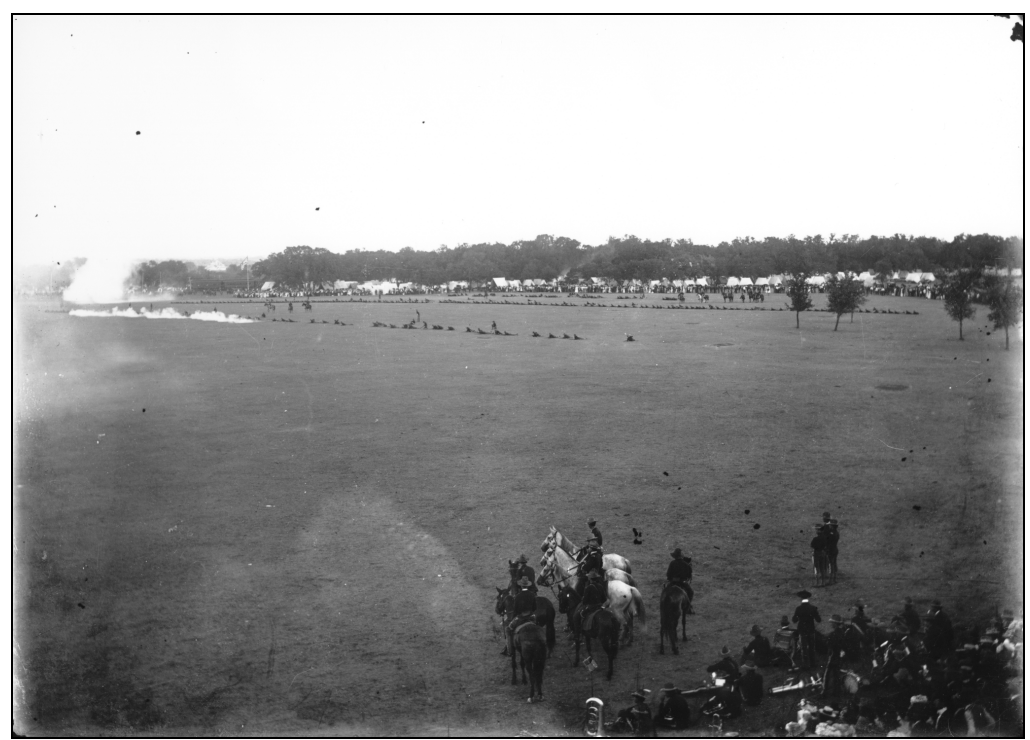

Figure 17. A "sham battle" at Camp Mabry, probably in the 1890s or early 1900s. Photo courtesy Austin History Center, PICA 08726.

The sham battles were an enduring social tradition, but in an era of very limited state support they also helped to raise funds for the Volunteer Guard and the Citizens Encampment Committee to improve and expand the camp. Between 1892 and 1902 the money seems to have been primarily used to pay off the Encampment Committee's debts and to raise money to rent properties surrounding the original 85-acre encampment ground. During that period the camp enclosed the improvements it had placed on Evard Townes' land, and expanded by renting properties across the tracks of the International \& Great Northern Railroad (Heligbrodt 1843).

Meanwhile, quite possibly because of the Encampment Committee's activities, the Townes family became embroiled in another lawsuit over land in the area. The Court finally ruled in 1894 that Evard was legally dead, and that his property east and west of the Colorado River would be divided amongst his surviving siblings. His property in what is now the Camp Mabry area was awarded to his sister, Pattie (Townes) Rector, and his brothers Allen and N. Cobbs. All four of the partitioned properties (Acquisition Tracts 7, 8, 9 and 10; see Figure 5) were finally deeded to the Citizens' Encampment Committee, and eventually the state (through trustees Iohn Peeler and D.W. Doom), and became legally part of the camp in 1902 (Figure 18). 


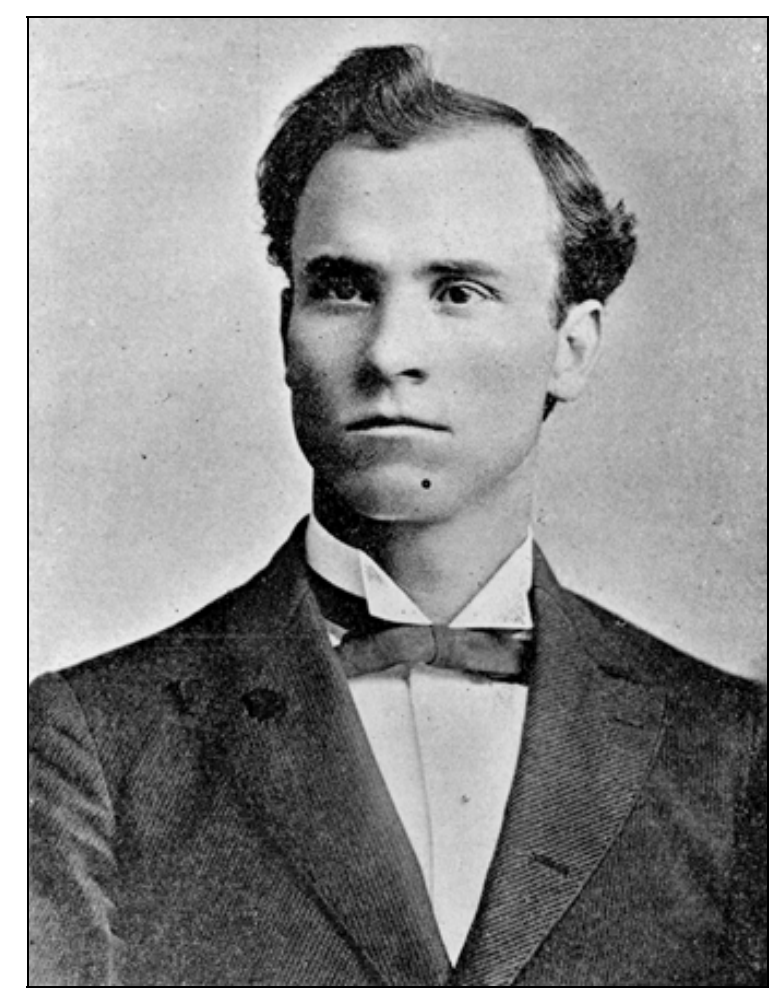

Figure 18. John L. Peeler, prominent Austin attorney and trustee for the Annual Encampment Committee. Photo courtesy of the Texas State Library and Archives.

The Spanish-American War of 1898 proved to be an important turning point for the Texas Volunteer Guard and the evolution of Camp Mabry. Despite Adjutant General Mabry's best efforts to professionalize the state's militia during the 1890s, state and federal attempts to mobilize for the war with Spain in 1898 exposed many embarrassing weaknesses in the Texas Volunteer Guard (and many other state militias). About twentyfive percent of the Texas militia units refused to volunteer for federal service against the Spanish, and many of the companies that did appear at the mobilization encampment in Austin were decimated by dropouts or by men who could not pass the physical examination. Only eight of the original 59 men of the La Grange Light Guards, for example, were mustered into federal service that May. Most of the Volunteer Guard units that did volunteer were initially poorly equipped and untrained for immediate action against the enemy (Leffler 1991; [Texas. Office of the Adjutant General] Report of the Adjutant General of the State of Texas for 1899-1900 Austin 1900:34-37).

Though the war with Spain proved to be short and relatively painless, military thinkers and members of Congress began to reformulate the structure, organization and funding of the nation's defense. In 1903 Congress passed the Dick Militia Act, which fundamentally reorganized the state militias, incorporated them into the U.S. National Guard, and devoted more federal money to their training and development. In 1905 the Texas Volunteer Guard was reorganized into the Texas National Guard, and over the next few years (with new infusions of state and federal money) training became more and more professional, and a number of improvements were added to the property: Camp Mabry's first target range, for example, was set up in 1906 (Figures 19 and 20). In 1909, 
the federal government almost doubled the original size of Camp Mabry when it funded the purchase of the "Old Deison Place," the 200 acres north of the original boundary of Camp Mabry (Acquisition Tract 1; see Figure 5). And that same year the Encampment Committee bought options to purchase other properties (Acquisition Tracts 2, 3 and 4) that Camp Mabry had formerly occupied by lease. All three options were exercised in 1913 (Heligbrodt 1943; Olson 1996; TCDR 234: 544-545; 234: 365).

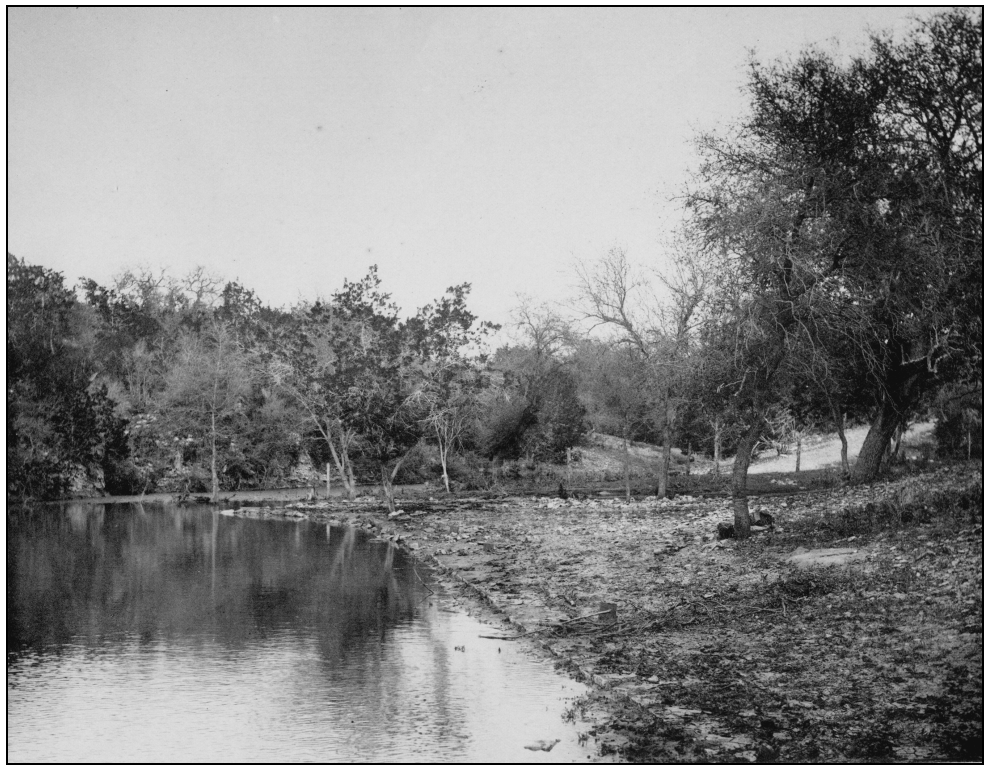

Figure 19. "Scene on the State Encampment Ground." From Art Work of Austin, (1894). Photo courtesy Austin History Center, PICA 02971.

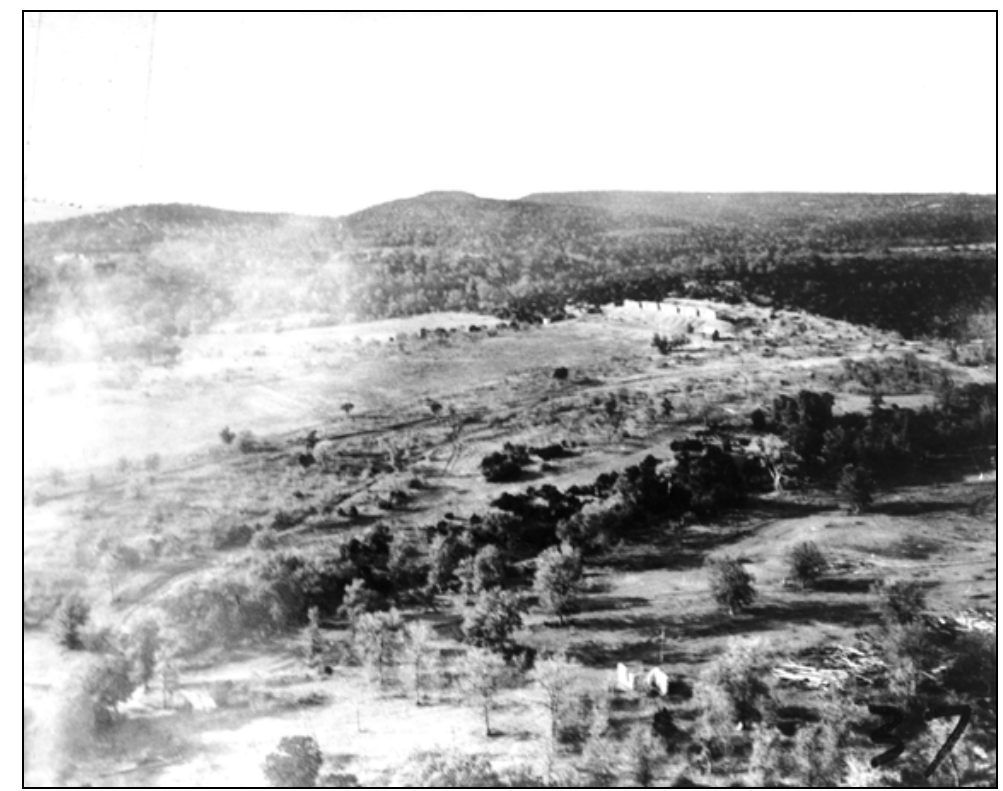

Figure 20. Overlooking Camp Mabry, circa 1907 (note target range near the center of the photo). Photo in Camp Mabry Historical Files, AGTX-EV, Camp Mabry. ${ }^{13}$ 


\begin{abstract}
Afterword
The evolution of the Camp Mabry area from plantations to parade grounds was in its own way unique. However, the changes there had not occurred in a vacuum: state, national and even international events had helped to shape the place. The Texas Revolution and annexation by the United States encouraged settlement in the area. The Civil War seriously disrupted its antebellum plantation economy. Postwar railroad construction encouraged development, and the Spanish-American War set into motion national military reforms that by 1913 had already played an important role in the area's evolution.

Many more changes would shape Camp Mabry in the years that followed, especially because of challenges presented during World War I, World War II, the Cold War and the nation's war against international terrorism that began after September 11, 2001. The old Edgemont plantation mansion, occupied by the Huck family since the 1870s, burned down in 1956, and its grounds were subdivided for a housing development. In 2002 no descendants of William Maben, Robert Townes, James Doxey or Charles Deison, the area's original settlers, could be found in the Austin area, and it is safe to say that few people living on Austin's Edgemont Drive (which pushes through

parts of Robert Townes' old plantation) know the origins of the name. For those aware of the area's history, though, some of the spirit of Edgemont Place still hovers over Camp Mabry and can never be entirely erased.
\end{abstract}

\title{
Acknowledgements
}

This study could not have been completed without the help of many people who contributed their knowledge and efforts to the project. Thanks first to Shelly Sullo Prewitt, Cultural Resources Director at AGTX-EV, Camp Mabry, whose interest in Camp Mabry's history made this project possible and who gave me generous access to Camp Mabry's extensive historical files and maps. Thanks also to Britt Bousman, director of the Center for Archaeological Studies at Southwest Texas State University, who patiently provided logistical support for the project. I am also indebted to other folks at SWT, especially Ray Umscheid (who produced the terrific maps for this study) and Karen Fustes, who expertly prepared the manuscript for publication. The study could not have been completed without a lot of help from staffers at the Austin History Center, Austin Public Library. I particularly want to thank Margaret Schlankey, the History Center's photo curator, for her extraordinary efforts on my behalf. Thanks also to the many hardworking staffers at the County Clerk's Office, Travis County Courthouse; the Travis County District Court, Travis County Courthouse; the Texas General Land Office, Austin; the Center for American History, University of Texas at Austin; and the Texas State Library and Archives, Austin. 


\section{Endnotes}

${ }^{1}$ Daniel Gilbert land grant file, Texas General Land Office, Austin (hereafter TGLO).

${ }^{2}$ The name appears as "Spear" on the land grant map, but my examination of the land grant documentation, deeds, and other evidence convinces me that the name was actually spelled "Speir." Spear land grant file Bastrop 1:61, TGLO; White (1966). Mrs. Speir does not appear on any Travis County census for 1840 or 1850, and Scallion appears on the compiled 1840 Travis County census only as an administrator for Speir's estate; he probably did not live in the county at the time, or not for long, and certainly did not live there by 1850 (See Carpenter 1969).

${ }^{3}$ The exact location of Heath Hall is uncertain. In a 1956 interview, Doxey's grandson remembered that "Heath Hall" was located "by Camp Mabry." The Texas Volunteer Guard campground was called "the old Doxey place" (Austin Daily Statesman [AD] July 12,1892), but there was no mention of a house on the property at that time. Then again, the Doxeys had moved to another house years before then.

${ }^{4}$ Gracy and Genter (1967:29) lists Townes' year of birth as 1800, but Friend (1996 6:539) and several other sources use the 1806 date.

${ }^{5}$ For other descriptions of the house and grounds see Austin Statesman (AS) April 17, 1927 and Austin American Statesman April 13, 1956. Number of children in 1855 extrapolated from Townes listing in Genter and Gracy (1967 p. 29). Pattie Townes's maiden name from index to Brown (n.d.) in Austin History Center, Austin Public Library.

${ }^{6}$ The names of the Townes children taken from "Application to confirm sale and distribute the money" in Case File 3738, J.B. Morris et al. vs. E.T. Eggleston et al., October 1876, Civil Case Records (CCR), Travis County District Court (TCDC), Travis County Courthouse, Austin. Two more children, Evart T. and Cobbs N. Townes, were born to Robert and Pattie between 1860 and 1863. See Petition to Court, November 1893, in Case file 11268, Pattie T. Rector et al. vs. N. Cobbs Townes et al. Case Files, TCDC, Travis County Courthouse.

${ }^{7}$ Deison's name does not appear in the county deed indexes until the 1870 s.

${ }^{8}$ Examples of his many land transactions can be found in deed to George Hancock David Webb, October 10, 1845 (Travis County Deed Records [TCDR] B: 76); deed to Hancock from Samuel Mills, April 6, 1849 (TCDR C: 502); Sheriff's deed to Hancock from Nancy Browning by Sheriff, March 61849 (TCDR D:33); Deed to Hancock from G.W Scott, June 19, 1852 (TCDR D:609); deed to Hancock from Thomas Champion by Sheriff, September 5, 1854 (TCDR 11: 218); two deeds to Hancock from Thomas Cassidy by Sheriff, April 3, 1855 (TCDR I:408, 427); deed to Hancock from Henry B. Andrews and wife, January 4, 1862 (TCDR P:317); deed to Hancock from Aaron Burleson, August 4, 1862 (TCDR Q:329).

9 "Lewis Hancock and Sunny Ridge," (undated manuscript) and Katherine Hart, "History Repeats in Austin" (undated clipping $A A S$ ) in "Hancock, Lewis" AF Manuscript file, Austin History Center, Austin Public Library), pp. 2-6.

10 "Answer of Debts," October 9, 1873, and "Decree Confirming Report of Partition of Land," June 23, 1874, in case file 3738, J. B. Morris et al vs. E.T. Eggleston et al, Civil Case Files (CCF, TCDC). The house was sold in 1875 for $\$ 4,000$ to Judge H.J. Huck, who was retiring to Travis County then after living many years in Indianola, Texas. After the Edgemont home burned down in 1956, its grounds were cleared and subdivided, and the Edgemont subdivision was built on the site. Rock from the old mansion's outbuildings was used in the construction of a number of homes in the area. The mansion was located about 200 yards west of present-day 3902 Balcones Drive in Austin. See "Decree Confirming Report of Partition of Land," cited above. "Francis Huck, Survivor of Hurricanes on Gulf Coast, Is Buried in Victoria" ( $A S$ November 16, 1953), and "Fire Levels Old Mansion in Foothills" (Austin American [AA] February 29, 1956). 
${ }^{11}$ Regarding Doxey move, see Hart (1956). Charles Deison does not appear on Travis County tax rolls for 1890 , and he had certainly died by 1895 , when his widow, Eliza, and the rest of his heirs sold 53 of their Camp Mabry acres to John and Lucy Gasser; 39 of those acres would eventually be incorporated into Camp Mabry as Acquisition Tract 2 (Moody 1991 p. 561); deed from Eliza Deison, et al. to John and Lucy Gasser, February 23, 1895 (TCDR 129:347); Option of Purchase from Stacy-Robbins Co. to Citizens Encampment Committee, July 28, 1909 (TCDR 234:544). Re Acquisition Tract 4 see deed from Lewis and Louisa Hancock to Richard Snell, et al., June 13, 1890 (TCDR 93:538) and deed from Austin Real Estate and Abstract Co. to State of Texas, July 6, 1909 (TCDR 234:365).

${ }^{12}$ Civil Case 11268, Pattie T. Rector et al. vs. N. Cobbs Townes et al., TCDC, Travis County Courthouse, Austin; deed from Pattie T. Rector to J.L Peeler, (TCDR 188:232); two deeds from D.W Doom to Peeler (TCDR 188:233-234); deed from R.H. Baker to Peeler (TCDR 183:46). 


\section{Chapter 5: Historic Context}

By Richard S. Jones

\section{Introduction}

The primary purpose of this chapter is to outline and describe several important historic and prehistoric research themes/topics, which can hopefully be addressed in either this specific survey or perhaps future investigations at Camp Mabry. The following prehistoric and historic research themes are discussed: (1) hunter-gatherer lithic technology and assemblage, (2) prehistoric human adaptation and subsistence, (3) European-American settlement at Camp Mabry, and (4) early military operations and activities within Camp Mabry. Within Section 3, Camp Mabry's modern landscape impacts this research design is discussed. If this survey results in the discovery of either historic and/or prehistoric sites, the close examination of these research issues will be necessary when making site eligibility recommendations for the National Register of Historic Places.

\section{Section 1. Prehistoric Considerations}

\section{Hunter-Gatherer Lithic Technology and Assemblage}

Introduction

Within this section I briefly describe how the study of hunter-gatherer lithic morphology characterizes the technology involved in making lithic tools, and how archaeologists interpret the variability in technology and assemblage formation as reflecting patterns of subsistence and mobility. The examination of lithic artifact assemblages and their technological variability has generated some controversial yet important insights relating to hunter-gatherer mobility and subsistence. Torrence (2001), Binford (1973, 1979), Bleed (1986), and Bousman (1993) are responsible for some of the leading hypotheses that relate hunter-gatherer subsistence strategy to lithic technology and assemblage.

Lithic Artifact Assemblages: Micro and Macro Scale Approaches

Before hunter-gatherers or lithic artifact assemblages can be studied, it is important to first decide whether to emphasize a micro- or macroscale theoretical approach. Macro- and microscale theoretical approaches emphasize opposing variables. According to Torrence (2001:74):

Macroscale theories use a comparative approach and emphasize environmental 
context, energy, raw materials and tools, whereas microscale theories normally

focus on particular cases and concentrate on social context, actors and knowledge.

According to Torrence (2001:75), the use of a macroscale theoretical approach to the study of lithic artifact assemblages attempts to "...elucidate the general processes that determine the overall character of hunter-gatherer tool-kits and the way they are manufactured and used." In other words, in the macroscale approach, regional outside forces are generally regarded as the primary cause of a technological trait and/or change in hunter-gatherer studies. Microscale approaches, however, generally put more emphasis on isolated individual causes (e.g., the individual of one group and/or family) for a technological trait and/or change in hunter-gatherer society.

\section{Variations in Hunter-Gatherer Lithic Tool Technology}

According to Binford (1973, 1979), lithic artifact assemblages can be classified by the degree of technology that was employed by hunter-gatherers in lithic tool manufacture. This variation in technology can fall under one of two categories: (1) expedient, or (2) curated. The topic of which lithic artifact types fall under these two categories, however, appears to be highly subjective in nature (e.g., what some scholars would label expensive, others would label expedient). Over the years, this controversial topic has generated intense debate within the archaeological community and resulted in further complicating the field of lithic analysis (see Tomka 1999; Bousman 1993; Bleed 1986). The following briefly relays the definition of expedient and curated technology I employed for this project. In Chapter 6, Goals and Methods, the artifact classification employed for this survey is briefly described, including which artifacts fall under either expedient or curated technological categories.

\section{Expedient Technology}

Expedient lithic artifact assemblages are those that can be produced quickly and have short periods of utilization. Flakes are removed in no systematic pattern, creating a nonstandardized core. In addition, expedient tools have a lower overall expense (e.g., no resharpening involved, and are not curated and/or transported). Expedient lithic technology is often employed in areas where there is an abundance of raw material present, or in close proximity (Parry and Kelly 1987; Schiffer 1975).

\section{Curated 'Expensive' Technology}

Curated lithic artifact assemblages are generally labeled 'expensive tools' because, opposed to expedient tools, they take longer periods of time and greater effort to manufacture (Binford 1979). Unlike expedient assemblages, curated lithic assemblages are generally designed for re-use, are highly maintainable (i.e., are repaired often and resharpened), are reliable, are used for a variety of tasks, and are regarded as easily transportable (Bousman 1993; Binford 1973, 1979). Curated lithic artifacts employ a predominate bifacial technology, with standardized (systematic) core reduction (Bousman 1993). However, depending on the amount of time and effort employed during 
manufacture, other lithic artifacts (i.e., unifaces, scrapers, and retouched flakes) could also fall under the expensive category (see Tomka 1999; Bousman 1993; Bleed 1986).

\section{Tool Assemblage and Mobility}

In recent years, archaeologists have discovered that the design, manufacture, and use of artifacts by hunters and gatherers is strongly linked to the specific exploitation pattern employed. Lithic tools are generally designed with a balance of three design goals: expediency, reliability, and maintainability, and their specific use reflects their continuing roles in the exploitation of resources (Binford 1973; Bleed 1986; Bousman 1993). According to Bousman (1993), prehistoric tool use appears to be very sensitive to changes in the patterns of hunter-gatherer resource exploitation, because the costs and benefits of tool designs that shift between reliability, maintainability, and expediency appear to be very different for these variables.

Theoretical Background

As previously stated, making determinations on subsistence patterns based on what appears in the archaeological record is extremely problematic, complicated, and very subjective in nature. According to Parry and Kelly (1987), foragers, as opposed to collectors, predominately employed an expedient lithic technology. However, while the vast majority of tools used by foragers were expedient in nature, foragers did utilize small numbers of highly valued/curated tools (Binford 1973, 1979; Vierra 1998; Bousman 1993). With this being said, some people might speculate that since foragers predominately employed expedient technology, forager occupations could then be identified as having greater proportions of expedient, over curated, artifacts within the archaeological record. However, even though this observation appears to be a logical deduction based on solid anthropological theory, this speculation would be highly debated within the archaeological community. Within the archaeological community, there are numerous competing theories which could directly apply and provide answers to the situation I presented above.

Web of Theories

Depending on which scholar or school of thought you prefer, the presence and/or lack of expedient or curated artifacts at a site could be interpreted as being indicative of occupations of foragers, collectors, or even both. Parry and Kelly (1987), and Binford $(1980,1983)$ would tend to interpret the predominance of expedient artifacts and lack of bifacial/curated artifacts at a site as being indicative of collector, as opposed to forager, occupations. Tomka (1999) however, would explain the lack of bifacial/curated artifacts at a site as possibly being caused by the high value foragers placed on curated (as opposed to expedient material) artifacts, thus foragers would be less likely to discard expensive curated material (as opposed to expedient material). In contrast to Parry and Kelly (1987), Tomka then, would tend to interpret the lack of curated technology at a site as possibly representing forager occupations. According to Schiffer (1975) and Shott 
(1989), the longer a site is utilized (i.e., collectors) the greater quantity and variety of curated/expedient tools should be present within the archaeological record. Thus, the lack of bifacial technology at a site is representative of forager, as opposed to collector, occupations (Schiffer 1975; Shott 1989). In addition, Vierra (1998) and Bousman (1993) believe that while both collectors and foragers employed curated technology, forager occupation would be indicated by a greater frequency of utilized interior flakes over formal curated tools within the archaeological record (Vierra 1998). Bousman (1993) has argued that foragers tend to curate extractive tools and use maintenance tools expediently, while collectors do the opposite (i.e., they use extractive tools expediently and curate maintenance tools).

New Perspectives

Within the archaeological community there is still intense debate concerning what does or does not constitute an expedient and/or curated lithic artifact (Bousman, personal communication 2002). According to Bousman, bifacial technology does not always equate to expensive/curative technology. There are many projectile points (i.e., Perdiz) and bifaces that can be produced in large quantities in short periods of time, and thus are considered very expedient in nature. In addition, variables such as; (1) the degree of maintainability (i.e., resharpening); (2) the intended use and/or function of a lithic artifact; (3) the availability and/or scarcity of resources; (4) the influence of technological inventions (i.e., the bow and arrow); and (5) the degree of sedentism, all play extremely important roles in determining what is, or is not curated and/or expedient (Bousman 1993). During periods when resources are scarce (i.e., the decline of bison within Texas during the Early and Middle Archaic, decline of megafauna during the Late Paleoindian) the relative value of curated artifacts (i.e., dart points) appears to have been extremely high. It is during these periods in which resources are scarce that some of the most technologically advanced dart points appear to have been produced (i.e., Folsom, Perdernales, Plainview). However, when resources are exceedingly rich, the value of maintaining highly curated artifacts appears to have been significantly reduced while the value/use of expedient tools increased (Bousman, personal communication 2002). However, during the Early Paleoindian period highly mobile hunter-gatherers employed highly valued/curated Clovis points when there were apparently numerous populations of megafauna (Willey 1966). The most commonly accepted reason behind this dichotomy appears to be based on the perception that during the Early Paleoindian, highly mobile populations were singularly focused on megafaunal 'big game' hunting (Willey 1966). However, work conducted on the Gault Site, located in Central Texas, recently exposed one of the best-preserved Paleoindian occupations recorded in North America. At the Gault Site, numerous expedient and curated artifacts were observed within what appears to be excellent context (Collins and Brown 2000; Collins et al. 2002). Excavations at the Gault Site suggest the Paleoindian inhabitants of Central Texas were, to a degree, quite sedentary and exploited a wider variety of resources than once perceived (Collins and Brown 2000; Collins et al. 2002). Thus, the Gault Site calls into question the long held belief, first proposed by Willey (1966), that Paleoindian populations were extremely nomadic in nature and subsisted entirely on 'big game' megafaunal hunting. 
Important Issues Related to Looting

Factors such as site disturbances and/or prior looting could also result in significantly altering and/or corrupting a data set to a high degree. Since looting by European-American populations has been prevalent in Texas for over 100 years, the surface quantity of curated artifacts and their ratio to expedient artifacts at many recorded and unrecorded archaeological sites, have been permanently altered. Another aspect of looting not usually considered by modern archaeologists is that many prehistoric sites could have been surface collected (i.e., looted) for thousands of years by the very prehistoric populations we are attempting to study. Today, what archaeologists describe as subsurface components on a prehistoric site, were actual ground surfaces at some point in antiquity (Schiffer 1987). Therefore, these surfaces in antiquity were possibly subjected to the same degree of surface collection (i.e., looting) that impact many prehistoric sites today. In fact, unless told by informants and/or other sources, an archaeologist would seldom truly know the degree to which a site has or has not been surface collected. Since many of the leading theories that equate lithic technology to mobility/subsistence are based on artifact inventories and assemblages, the issue of looting could seriously call into question the reliability and/or relevancy of many of these long held theories.

Summary

As previously stated, making sound scientific judgments regarding group subsistence and mobility based on the types of lithic technology observed within the archaeological record is extremely problematic and subjective in nature. In the majority of cases, numerous competing theories will apply to a given situation. Thus, in order to make any suggestions on group mobility based on lithic artifact technology, it is extremely important that one understand all the competing theories.

\section{Prehistoric Human Subsistence and Adaptation}

One of the best ways to record the interactive relationship between prehistoric populations and the natural biotic landscape (i.e., plants and animals) is the thorough examination of burned rock features/middens and floral/faunal remains observed in archaeological sites. Detailed examination of this data can lead to interesting insights regarding; 1) the specific floral/faunal resources being consumed, 2) the seasonality of resource exploitation at a specific site, 3) the way in which these resources were being utilized, 4) the scale of mobility, and 5) the role a site played within a regional settlement system (Vierra 1998:33; Potter et al. 1995).

Although botanical remains have been found at archaeological sites within geographic upland portions of Central Texas they are usually not particularly well preserved. Like floral remains, faunal remains are also usually observed in a state of poor preservation (Black 1989c:36). The scientific validity and utility of floral and faunal remains recovered within the project area depends entirely on the degree of preservation 
noted during excavation and/or soil floatation. Thus, any biotic remains recovered during this survey should be considered highly significant and, hopefully, could provide important clues relating to the specific type of floral/faunal resources being consumed and the seasonality of exploitation.

The careful examination of burned rocks noted within archaeological sites can provide some interesting scientific insights regarding prehistoric human subsistence and adaptation. The analysis of charred biotic remains within burned rock features provides, in essence, a temporal anchor in which to analyze other types of archaeological evidence recovered (i.e., biotic materials). In addition, the specific size and number of burned rock features noted within an archaeological site is generally regarded as a proxy measure of the amount of food that was cooked at a specific feature/site and the temporal intensity of site utilization. Smaller burned rock features are commonly regarded as the most efficient means of cooking resources for smaller populations, which only inhabit a specific site for short durations (Vierra 1998). Larger burned rock features, opposed to smaller features, are commonly regarded as an inefficient means of cooking resources for larger populations. Thus, the relative size and number of burned rock features observed at archaeological sites can directly relate to group size, length of occupation, and quite possibly the degree of mobility (Vierra 1998).

\section{Prehistoric Archaeological Expectations}

According to Black (1989b:19-21), numerous archaeological site types have been observed and recorded in Central Texas. Some of the main site types that Black (1989b) attributes to the Central Texas area, and could be observed during the Camp Mabry survey, include: open campsites, burned rock middens, rockshelters, and chert quarry sites.

Open Campsites

Open campsites originate from the temporary habitation of an area by a group of hunters and gatherers. Open campsites may consist of either a single-occupation surface artifact scatter, or deep multicomponent deposits that represent thousands of years of occupation. In addition, fire cracked rock (FCR) from burned rock features (i.e., hearths, and middens) are often noted within the confines of open campsites. One open campsite (41TV1667) has been recorded during previous surveys within the project area (see Chapter 3). It is quite possible that additional open campsites will be observed during this survey of Camp Mabry.

Rockshelters

Within Central Texas, rockshelters are commonly observed in solution cavities along creeks where water has cut into limestone bedrock. When intact, rockshelters are regarded as archaeologically significant because they often reflect a series of occupational episodes going back (in some cases) thousands of years. In addition, 
rockshelter environments are typically conducive to the preservation of both floral and faunal remains. Thus, anytime a rockshelter is encountered during a survey, it should be regarded as potentially significant and be subsequently investigated for the presence of intact cultural resources. Unfortunately, the chance of observing a pristine rock shelter in Texas, which has not been looted, is extremely low. A review of the THC Atlas database revealed the presence of one rockshelter (41TV47) located approximately 3 kilometers to the northwest, within the same 'Balcones Canyonland' setting as the western portion of Camp Mabry. Due to the presence of previously recorded rockshelters within 3 kilometers of the project area, it is possible that additional rockshelters will be encountered during this survey.

\section{Burned Rock Middens}

Burned rock middens (BRMs) are commonly observed within portions of Central and West Texas. According to Black (1989b:19), burned rock middens are usually located within terrace or upland settings of the Edwards Plateau and are commonly surrounded by various cultural debris, which are indicative of artifacts associated with prehistoric open campsites. BRMs can range in size from a few meters in diameter to a hectare, and are commonly observed in clusters of two to a dozen (Black 1989c:19). The manner in which these sites were both formed and utilized has been a topic of intense archaeological debate (see Black et al. 1993; Prewitt 1991) within the archaeological community for over 50 years. Numerous BRMs were recorded 5 kilometers north of Camp Mabry within a similar geographic setting (see Weir and Briggs 1997). Thus, it would not be surprising if burned rock middens were encountered during this survey of Camp Mabry.

\section{Chert Quarry Sites}

In Central Texas, chert quarry sites are usually located in upland Edwards Plateau settings where high quality Edward chert deposits are easily accessible in Edwards Group limestone formations. Quarry sites are also known to appear within drainages where river-transported chert nodules are abundant and easily accessible. Since this project area is located within the eastern portion of the Edwards Plateau and has easy access to Edwards chert formations, it is quite possible that a chert quarry site could be encountered during this survey.

\section{Section 2. Historic Considerations}

A number of important research issues could be addressed for the historic period in the Camp Mabry survey area. What is the nature of European-American settlement of the Camp Mabry region? Can these early European-American settlement zones be located within the highly disturbed landscape of modern Camp Mabry? What was the nature of Camp Mabry's early military presence? Is Camp Mabry's early military presence still apparent within the modern geographical landscape? 


\section{Historic Archaeological Expectations}

European-American Settlement

As previously discussed in Chapter 4, European-Americans first began to settle Camp Mabry in the early nineteenth century. Some of the early settlers of Camp Mabry included individuals who played significant roles in the economic and political development of Austin, Travis County, and the State of Texas. Prior to Camp Mabry's establishment in 1892, numerous other institutions had occupied the grounds of Camp Mabry (e.g., living quarters/houses of both slaves and European-American settlers). Archaeological investigations within the confines of Camp Mabry could provide very significant information that relates to these important early nineteenth century establishments. In particular, there appears to be a likelihood that elements of the historic homestead of Charles W. Deison may be encountered during this survey. The Deison residence was the only historic/early nineteenth century homestead observed occupying the project area on a 1906 map of Camp Mabry (see Chapter 4, Figure 9).

\section{Early Military Presence}

Prior to the establishment of Camp Mabry as a military post in 1892, the region was quite possibly visited by armed soldiers, who accompanied early Spanish entradas into this region during the late seventeenth and early eighteenth centuries. However, the likelihood of encountering archaeological evidence of these brief visits is very remote. If archaeological evidence is found of these early Spanish entradas it will, more than likely, be an isolated find in a disturbed/contaminated context. As previously stated, historic Camp Mabry first became an operational military post in 1892. During this survey it is quite likely that historic military elements contemporaneous to this ca. 1890 time period (e.g., old firing ranges, remnants of early military structures, etc.) could be encountered during this survey project. A review of historic maps and archival data (see Chapter 4) suggest that these early military formations/structures could be encountered during this survey.

\section{Section 3. A Problem That Cannot Be Ignored}

While forming the prehistoric and historic research design for Camp Mabry, the problem concerning modern Camp Mabry's highly disturbed landscape could not be ignored. Unfortunately, due to the high percentage of disturbed areas present on Camp Mabry's modern landscape (see Chapter 2, Figure 2), the research design for this survey cannot help but be impacted in both size and scope. It is hoped that during this survey important prehistoric and historic archaeological resources, which relate to this research design, are encountered within undisturbed portions of Camp Mabry. However, if these prehistoric and historic sites are not encountered during this survey, it does not necessarily mean that they did not exist within the project area. Within the project area, there is a relatively large area (see Chapter 2), which has been covered by vast amounts 
of matrix in order to produce artificial terraces. Amazingly, it is quite likely that intact archaeological resources remain buried under these artificial terraces (Figure 21). Due to this very real possibility I recommend that if deep/large-scale landscaping is conducted within terraced portions of Camp Mabry in the future, archaeological monitors should be present in the event that archaeological resources are uncovered.

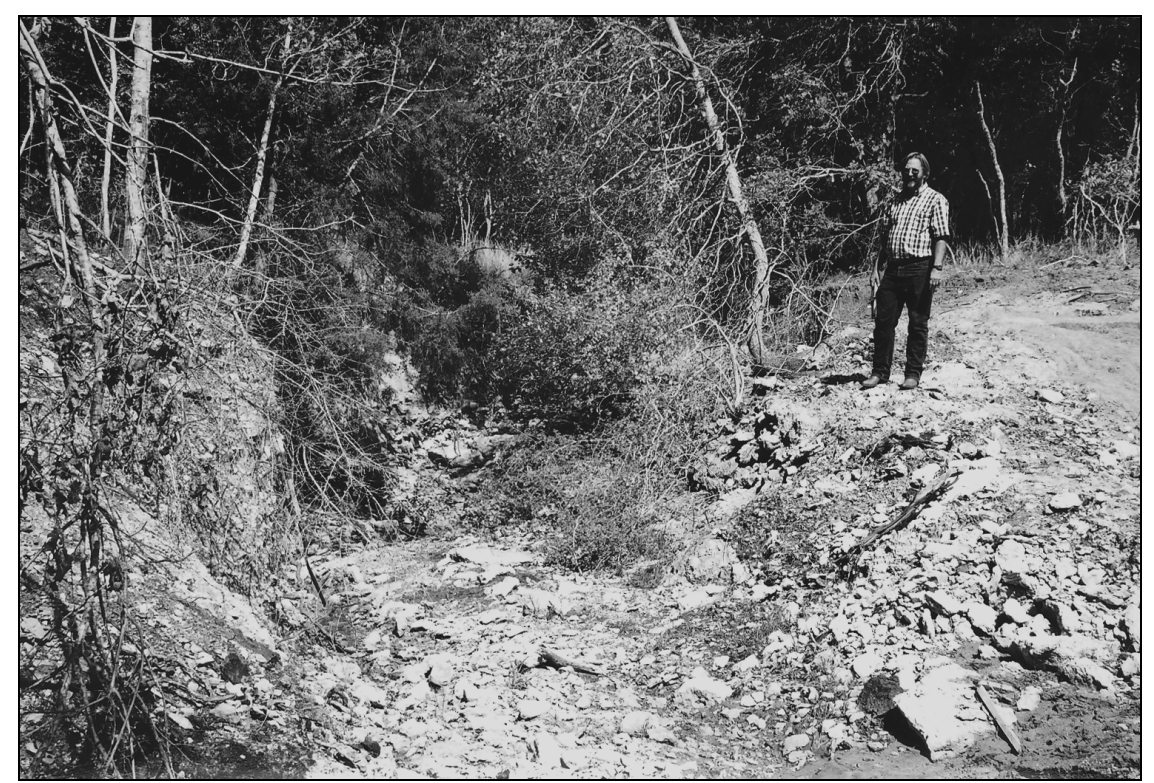

Figure 21. Photograph of Britt Bousman standing on one of the numerous artificial terraces located within Camp Mabry. 


\section{Chapter 6: Goals and Methodology}

By Richard S. Jones

\section{Goals}

The primary goals of the Camp Mabry survey were; (1) to conduct a systematic and intensive archaeological survey on 275 acres in order to locate, record, and access the National Register eligibility of cultural resources found therein; (2) to conduct thorough historic literature and archival research in order to develop the history of early Camp Mabry and its relationship to the surrounding community; (3) to develop a comprehensive historic context, which outlines important theoretical issues that are pertinent to the project area; (4) conduct both surface and subsurface investigations throughout the entire project area in order to locate historic/prehistoric cultural resources and subsurface geology; (5) to report all cultural resource data generated during the survey and provide National Register eligibility recommendations to THC so the AGTX can preserve cultural resources while maintaining military readiness at Camp Mabry.

\section{Methods}

\section{Pre-field Preparations}

Prior to conducting archaeological investigations on Camp Mabry, CAS personnel met with the AGTX-EV director in order to discuss various aspects of fieldwork and reporting standards. Modern and historic aerial photographs, previous Section 106 archaeological surveys, topographic maps, historic literature, and geologic surveys were extensively reviewed in order to gather a better understanding of Camp Mabry's archaeological context prior to fieldwork. Data files from the Texas Archeological Research Laboratory and the Texas Historical Commission were collected and extensively reviewed for pertinent information. Background research suggested that both historic and prehistoric cultural resources were likely to be encountered during the 275acre survey. Pre-field investigations for the Camp Mabry survey were preformed by one of the project's Principle Investigators and the Project Archaeologist.

\section{Field Investigations}

The archaeological survey on Camp Mabry was conducted in two phases, which occurred during different time periods. A combined total of two backhoe trenches and 149 shovel tests were excavated during the course of the survey (Figure 22). 
FIGURE 22. REDACTED

Figure 22. Map of Camp Mabry showing shovel test and site locations.

Phase 1

In response to the heightened state of security on all military installations following the September 11, 2001 bombing of the World Trade Center, the AGTX initiated plans for the construction of a new perimeter fence on Camp Mabry. On September 13, 2001, CAS was contacted by AGTX-EV and asked to perform an ad hoc archaeological survey of Camp Mabry's 30-X-3,750-meter perimeter fence line in order to determine if cultural resources would be adversely impacted. The survey was performed on September 17, 2001 by one staff archaeologist under the direction of the Project Archaeologist and Principle Investigator. A total of 20 shovel tests were excavated along the perimeter fence line during this phase of the survey.

Phase 2

The 275-acre archaeological survey of Camp Mabry was conducted October 1519, 2001 by three staff archaeologists under the direction of the Project Archaeologist. The purpose of this archaeological survey was to identify and document prehistoric and 
historic cultural resources within the confines of Camp Mabry. During this phase of the survey a total of two backhoe trenches and 129 shovel tests were excavated.

\section{Pedestrian Survey}

As expected, the pedestrian survey was significantly affected by the highly disturbed nature of the present Camp Mabry landscape (see Chapter 2). Camp Mabry's 137.5 acres of intact/undisturbed property was intensively surveyed following the standards set fourth by the Texas Historical Commission. Transects were established 30 meters apart and were traversed at specific degree bearings using compass navigation techniques. The landscape was thoroughly investigated in order to locate visible historic and prehistoric cultural resources/features. When artifacts were observed on the surface, the immediate area was thoroughly investigated to determine if the artifact was in the context of a site, or was an isolated find. When sites were encountered during the pedestrian survey: flagging tape was used in order to identify artifact locations and site boundaries, field maps/notes were made, $35 \mathrm{~mm}$ black and white prints and $35 \mathrm{~mm}$ color slides were taken, shovel test locations were established, total site surface or 5-meter dogleash inventories were performed, a field site number was established, and Global Positioning System (GPS) measurements were taken. On the 137.5 acres of highly disturbed property within the Camp Mabry project area, crewmembers were systematically spread out over the landscape in order to identify cultural resources on the surface and excavate appropriate shovel tests (see Figure 22).

\section{Shovel Testing}

The primary goal of shovel test excavation was to identify subsurface cultural resources. A shovel test was defined as a $30 \mathrm{~cm}$ diameter unit, that has been excavated, screened, collected and recorded in levels no more than $10 \mathrm{~cm}$ in thickness, to a depth of $50 \mathrm{~cm}$ below surface, or until bedrock or sterile soils were encountered. Additional levels below $50 \mathrm{~cm}$ were excavated when deep cultural resources were encountered. All matrix removed was put through a $1 / 4$-inch hardware cloth. A shovel test form was completed for every shovel test excavated during the survey. On the shovel test form, detailed notes that delineate the nature of soils encountered during excavation, as well as the extent of artifact deposition were recorded when appropriate.

Within areas of Camp Mabry not affected by artificial impacts, CAS archaeologists systematically excavated shovel tests on a 60-meter grid. In areas found to be highly disturbed in nature, shovel tests were systematically excavated on a 120-meter grid (Figure 23). Every shovel test was assigned a number and GPS measurements were taken. Within the context of archaeological sites, the project archaeologist would establish a sufficient number of shovel tests in suitable locations so as to determine the horizontal and vertical extent of artifact deposition, in addition to archaeological site boundaries. 


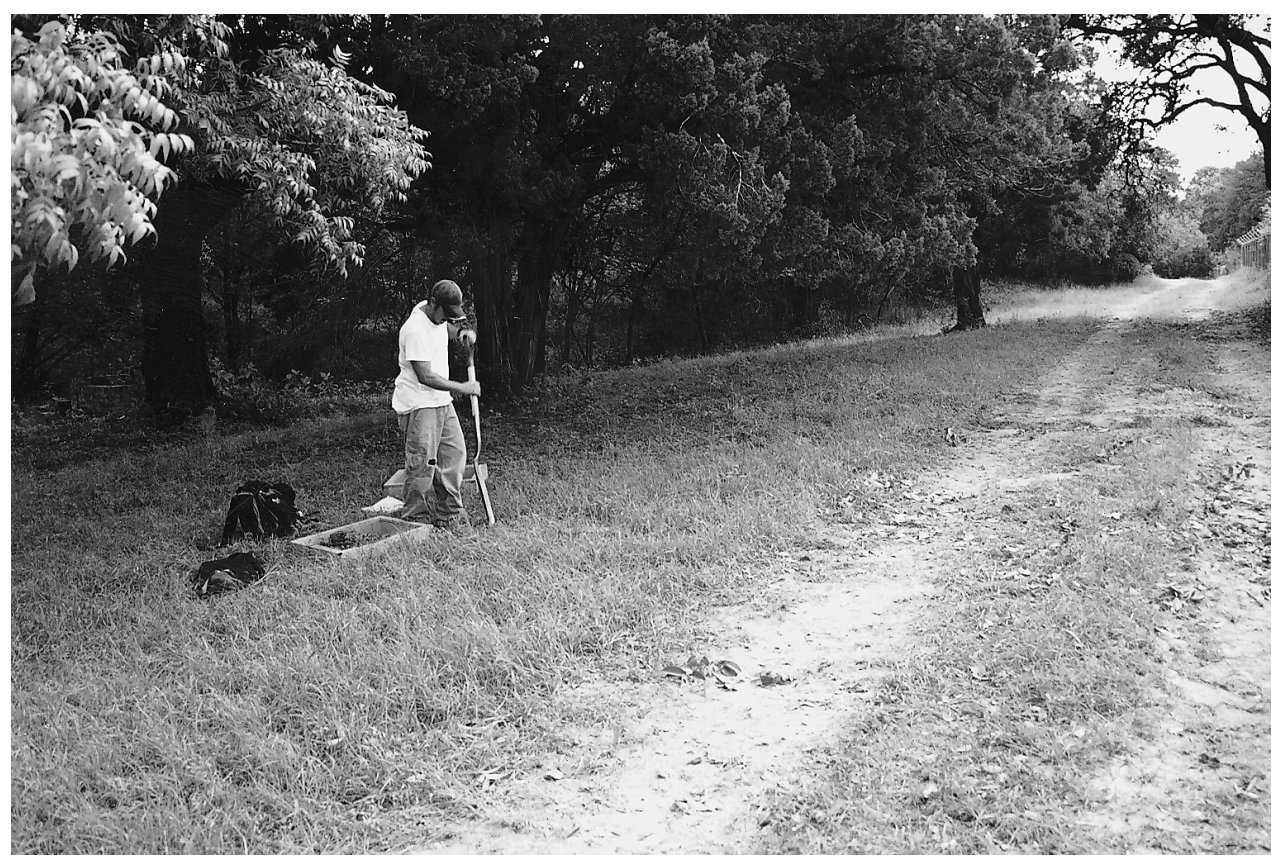

Figure 23. Staff archaeologist Antonio Padilla excavating ST A.

\section{Backhoe Trenches and Geomorphologic Profiles}

In order to examine geologic processes and the extent of cultural deposition present at prehistoric site 41TV1667, two backhoe trenches were excavated within the confines of the site. All descriptive profiles and field notes were performed by the Coprinciple Investigator, Dr. Britt Bousman, who also served as Project Geomorphologist.

\section{Field Collection Procedures}

All artifacts recovered from shovel testing were collected, bagged, and the bags labeled with the appropriate provenience. Diagnostic and shovel test artifacts were collected. In addition, full site and/or 5-meter dogleash surface inventories were performed in order to record the surface artifact assemblage and density of archaeological sites.

\section{Lithic Artifact Definitions and Attributes}

During this survey, numerous lithic artifacts were recorded during site/dogleash surface inspections, and collected during shovel test excavations. All artifacts were extensively analyzed for traits that would distinguish them as employing either expedient or curated technology. Curated artifacts were classified as tools which; 1) require a high degree of time and effort to manufacture, and 2) employ predominately bifacial technology with standardized core reduction (i.e., projectile points and bifaces). Since utilized interior flakes are predominately related to the reduction and/or manufacture of 
curated tools and/or standardized cores, for this study they are included in the curated category (Vierra 1998). The following artifact types are placed into the expedient category: exterior flakes, cores, crudely manufactured unifaces, and tested cobbles (Parry and Kelly 1987).

\section{Projectile Points}

Projectile points are one of the more important artifact categories because they can be assigned both temporal and cultural affiliations, based on the commonly accepted point chronology developed for Central Texas (i.e. Turner and Hester 1999). Projectile points are usually classified into the following sub-category: arrow point, arrow point preform, arrow point blank, dart point, dart point preform, or dart point blank. Blanks are usually described as bifacial artifacts that are approximately the same size as projectile points but lack notching. Projectile points that are not similar to previously established types were labeled 'untyped'. This designation is generally reserved for fragmentary specimens of projectile points, which lack diagnostic attributes.

\section{Cores, Tested Cobbles, Debitage, Flakes, and Shatter}

Cores are defined as chert nodules that have faceted platforms from which specific kinds of flakes are removed. Tested cobbles are nodules with a single flake removed from an unprepared cortical platform at one or more isolated locations. Debitage consists of the lithic by-products of core and tool production. Flakes are pieces of material that have been detached from a core or tool by percussion or pressure. For this survey the category 'shatter' is defined as non-cultural angular debris, which is the byproduct of mechanical crushing (i.e., chert cobble that has been run over by a steam roller).

\section{Retouched Tools}

Retouched tools (i.e., bifaces, unifaces, and in some cases flakes) are the result of the secondary percussion or pressure flaking of a piece in order to produce a specific tool shape.

Unifaces can be described as artifacts which display retouch scars over one-third or more of only one of their surfaces, exhibit initial edge retouching, and also lack a formal overall shape (Vierra 1998:119). In contrast, scrapers can be described as a specialized form of uniface, which display secondary edge retouch resulting in a tool with an edge angle between 60-80 percent (Vierra 1998:119).

Bifaces are defined as artifacts that exhibit retouch scars extending over one-third or more of both of their opposing surfaces (Chapman and Schutt 1977:93; Vierra 1998:119). Projectile points are also considered bifaces that exhibit hafting modifications that distinguish a stem from the blade (Vierra 1998:119). 


\section{Laboratory Procedures}

The artifacts recovered during the survey were processed in the CAS laboratory between October and November 2001. Artifacts and project materials were prepared for storage in accordance with Federal Regulation 36 CFR Part 79, and in accordance with current artifact curation standards established by the Texas Archeological Research Laboratory (TARL). All artifacts were washed, labeled, and inventoried before being sent to TARL for curation along with all records, photographs, and slides.

\section{Site Forms and Mapping}

Archaeological site trinomial numbers were assigned to CAS by TARL. All archaeological site data recorded in the field was subsequently transferred to TexSite software for filing with the TARL. In addition to all other maps produced during the Camp Mabry survey, CAS provided the AGTX with two 7.5' series USGS maps which displayed site locations, site boundaries, areas surveyed, and shovel test locations. 


\title{
Chapter 7: Site Descriptions and Results
}

\author{
By Richard S. Jones
}

\section{Introduction}

This chapter discusses results gathered from the 275-acre intensive survey conducted within the confines of Camp Mabry. The survey resulted in the discovery of an 8-x-8-meter prehistoric site, 41TV1954. Two previously recorded prehistoric sites, 41TV1722 and 41TV1667, within the survey area were revisited during the survey in order to access their eligibility for inclusion to the National Register of Historic Places. Prehistoric site 41TV1721 was observed in a highly disturbed state outside of the contracted 275-acre project area (see Figure 22).

\section{TV1722}

Originally recorded in 1994 by personnel from AGTX-EV, archaeological site 41TV1722 was revisited and tested during this survey in order to reevaluate its potential for NRHP eligibility. The site is located on a sloped, upland setting within the westcentral portion of Camp Mabry, and 150 meters east of the Barrow Brook drainage (Figures 24 and 25). According to Werchen et al. (1974), the soils observed at 41TV1722 are of the Tarrant (TeA) series classification. In non-developed areas, Tarrant soils are described as being a dark grayish-brown clay or clay loam, which extends 8 inches below the surface. Below 8 inches, limestone bedrock typically forms the underlying component (Werchen et al. 1974). At the time of the survey, thick brush (e.g., greenbrier and cedar) covered approximately 70 percent of the site, thus limiting site surface visibility to approximately 30 percent. Upon examination, 41TV1722 appeared to be heavily disturbed by both natural and artificial impacts. Throughout the site, numerous $50 \mathrm{~cm}$ to 1 $\mathrm{m}$ wide gullies were visible running down slope in a northwesterly direction towards an unnamed ephemeral drainage. In addition, extensive water erosion on 41TV1722 has exposed the underlying limestone bedrock in approximately 30 percent of the site. On the far western portion of the site, a moderately used, 3-4 meter wide, north-south running dirt road was observed cutting through the site. Water runoff from the road appears to have hastened the effects of water erosion that, as previously stated, has impacted a significant percentage of the site. 


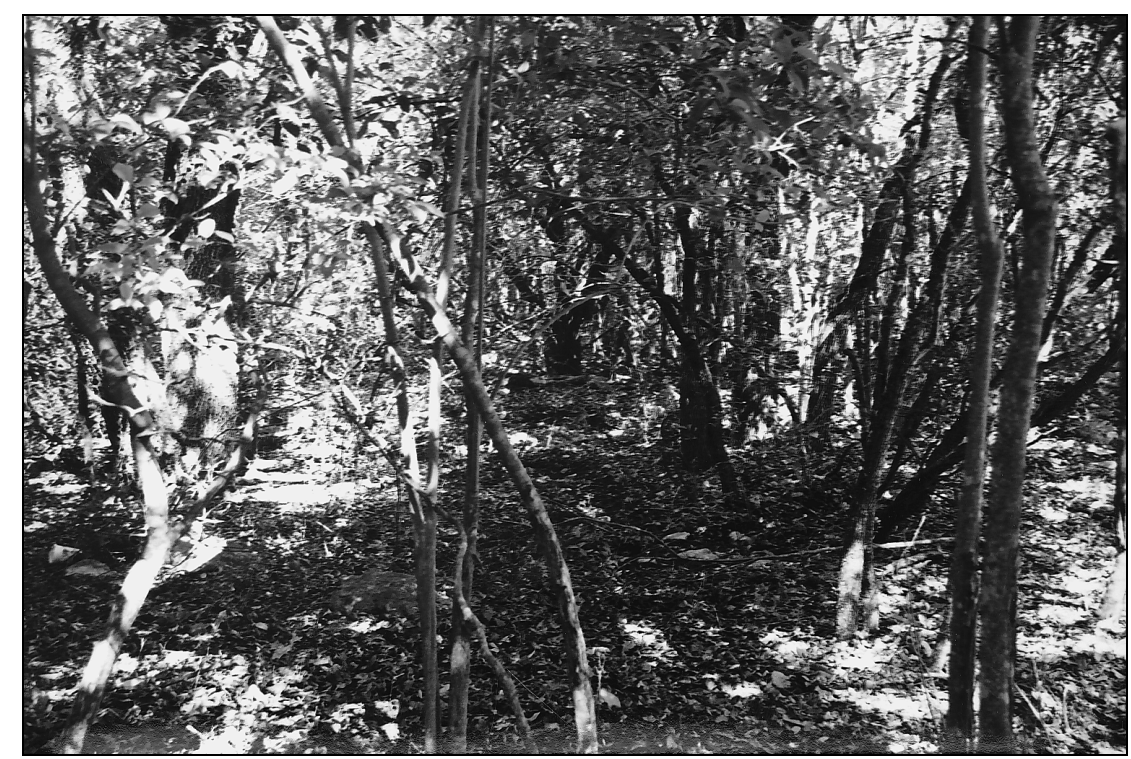

Figure 24. 41TV1722, facing north.

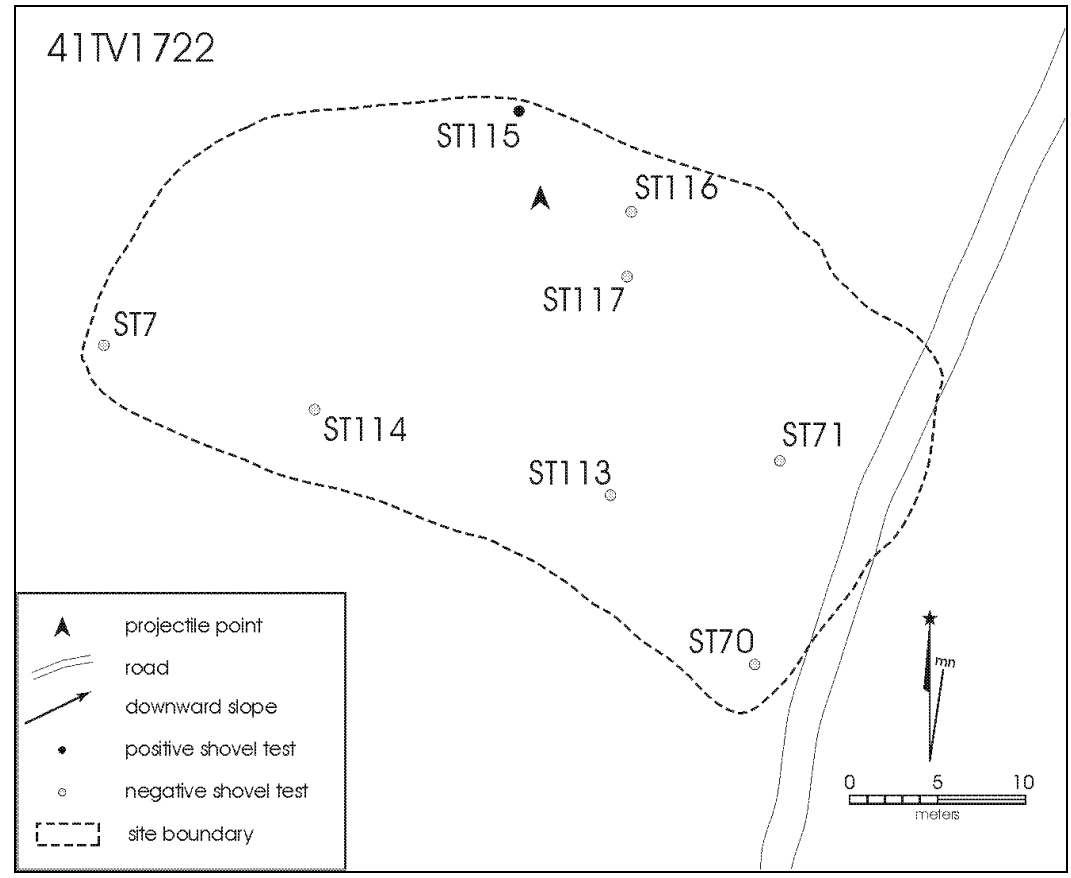

Figure 25. 41TV1722 map showing shovel test locations.

\section{Results}

A 100 percent surface artifact inventory was performed in order to thoroughly record cultural resources on this site, which is in danger of being totally impacted from continued water erosion (Table 1). 
Table 1. 41TV1722 surface artifact inventory.

\begin{tabular}{|l|r|r|l|l|l|l|r|r|}
\hline & & & Bifacial & Unifacially & Bifacially & & \\
\hline & Exterior & Interior & Thinning & Retouched & Retouched & & \\
\hline Size & Flakes & Flakes & Flakes & Flakes & Flakes & Uniface & Biface \\
\hline$<3 \mathrm{~cm}$ & 16 & 51 & 0 & 2 & 0 & 2 & 0 \\
\hline$>3 \mathrm{~cm}$ & 5 & 7 & 3 & 5 & 3 & 5 & 3 \\
\hline$>5 \mathrm{~cm}$ & 1 & 0 & 0 & 3 & 0 & 3 & 0 \\
\hline$>7 \mathrm{~cm}$ & 1 & 0 & 0 & 0 & 0 & 0 & 0 \\
\hline Totals & $\mathbf{2 3}$ & $\mathbf{5 8}$ & $\mathbf{3}$ & $\mathbf{1 0}$ & $\mathbf{3}$ & $\mathbf{1 0}$ & $\mathbf{3}$ \\
\hline
\end{tabular}

While performing initial reconnaissance on the site, the proximal tip of an unidentified projectile point was observed on the surface in the north-central portion of the site (Figure 26). Despite being just a fragment, the proximal portion did display some characteristics attributed to projectile points temporally assigned to the Late Prehistoric time period (i. e., relative thinness, and the use of fine pressure flaking techniques). However, assigning temporal associations for incomplete/fragmented projectile point specimens are extremely speculative and problematic in nature. The remaining portion of the point is needed in order to confirm the specific period of manufacture.

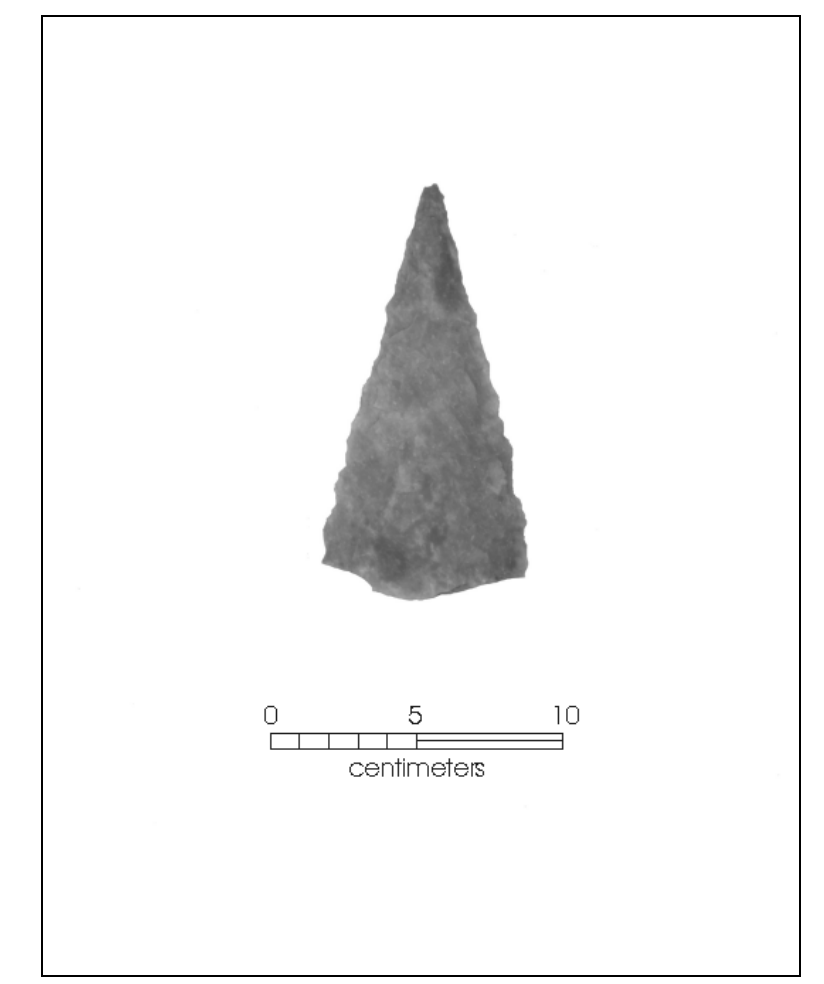

Figure 26. Projectile point tip found at 41TV1722.

In order to determine the extent of vertical and horizontal artifact deposition, a total of eight shovel tests were excavated within the confines of the site. Of the eight shovel tests excavated, only one (shovel test 115) yielded subsurface cultural resources (two interior flakes at $10-20 \mathrm{~cm}$ below surface). It appears that extensive water erosion 
has eroded away the majority of previously buried cultural material. The majority of surface artifacts were observed within water gullies and eroding approximately $25 \mathrm{~m}$ down slope of the site center. In addition, surface artifact densities gradually declined the farther one traveled down slope. These observations are typical of sites heavily impacted by water erosion. By documenting the extent of surface artifact deposition, prehistoric site 41 TV1722 was found to be approximately $25-x-50$-meters in size.

\section{TV1667}

Originally recorded in 1993 by personnel from AGTX-EV, prehistoric site 41TV1667 was revisited during this survey in order to reevaluate its potential for NRHP eligibility. The site is located 350 meters northwest of 41TV1722, within the heavily wooded western portion of Camp Mabry. According to Werchen et al. (1974), the soils observed at 41TV1722 are of the Volente (VuD) series classification, which normally occupy both valleys and foot slopes. In Volente soils, the typical geologic pedon consists of a dark grayish brown calcareous clay loam 'A Horizon' (0-22 inches below surface) followed by brown silty clay 'B Horizon' (22-46 inches below surface). Below 46 inches, a reddish-yellow clay loam forms the underlying geologic ' $\mathrm{C}$ Horizon' component. At the time of the survey, thick brush (i.e. cedar and greenbrier) covered approximately $75 \%$ of the site, thus limiting ground visibility to approximately $25 \%$ (Figure 27 ).

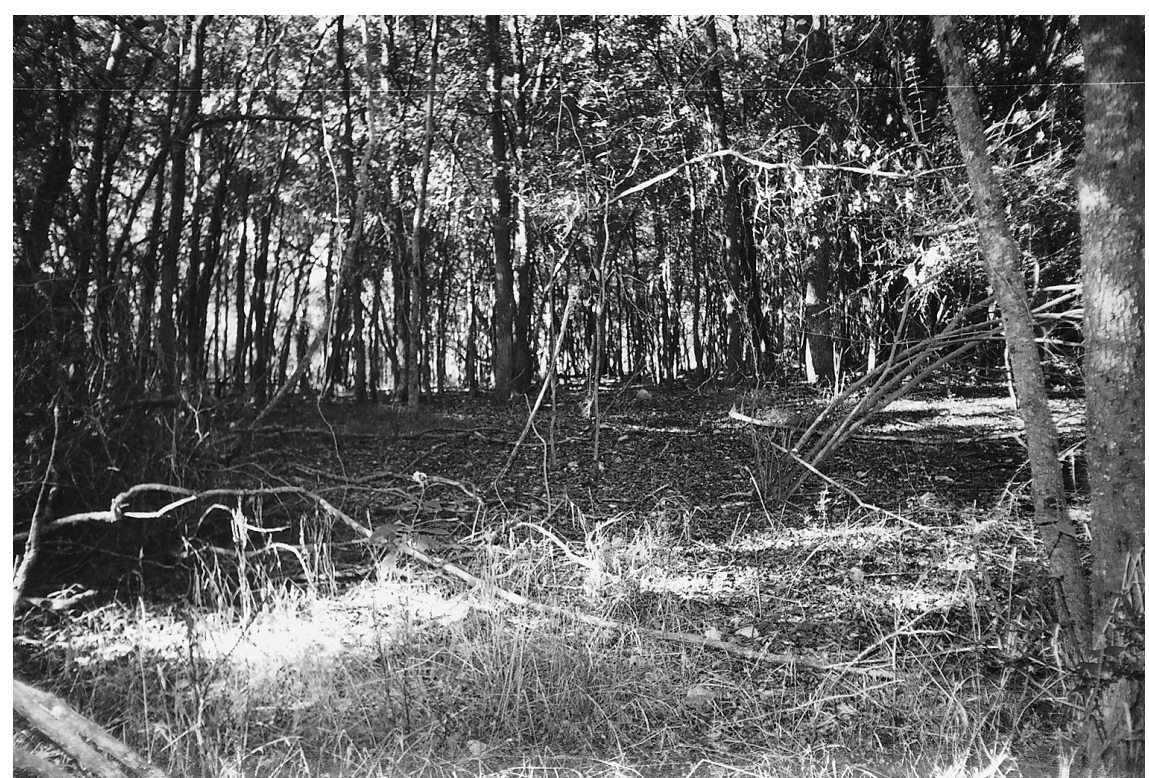

Figure 27. Photograph of 41TV1667 showing Barrow Brook in the foreground.

Upon examination, 41TV1667 appeared to be heavily disturbed by both natural and artificial impacts. Barrow Brook was observed running through the central portion of the site in a northwest to southeast direction. The brook itself can be described as an ephemeral seasonal brook, which eventually drains into the Colorado River (located 3 kilometers southwest of 41TV1667). The portion of Barrow Brook that directly impacts the site was approximately 5 meters in width and contained no standing water. As 
expected, Barrow Brook appears to have impacted cultural resources at the site. Small to moderate amounts of lithic material were observed eroding from the brook's exposed cut banks. A buried sewage line was observed running alongside Barrow Brook through the central portion of the site (Figure 28). In order to install the sewage line an $8 \mathrm{~m}$ wide area was graded along the southern edge of Barrow Brook to a depth of $50 \mathrm{~cm}$ to 1 meter. As expected, the sewage line tremendously impacted the south-central portion of the site. A small to moderate amount of lithic artifacts were observed eroding away from the graded cut bank. Also, during the survey two moderately used dirt roads were noted running through the site (see Figure 28). In order to construct these roads, a 4-m wide area was graded to a depth of approximately $20 \mathrm{~cm}$ below surface. One of the roads ran in a northwest to southeasterly direction through the central portion of the site. The other road ran in a northeast to southwesterly direction on the far eastern portion. The construction of both roads appears to have moderately impacted cultural resources at 41TV1667. Small amounts of lithic material were observed along the side of both roads within the context of graded push piles. During the survey, all disturbed/impacted areas on the site were mapped and extensively examined for exposed diagnostic artifacts.

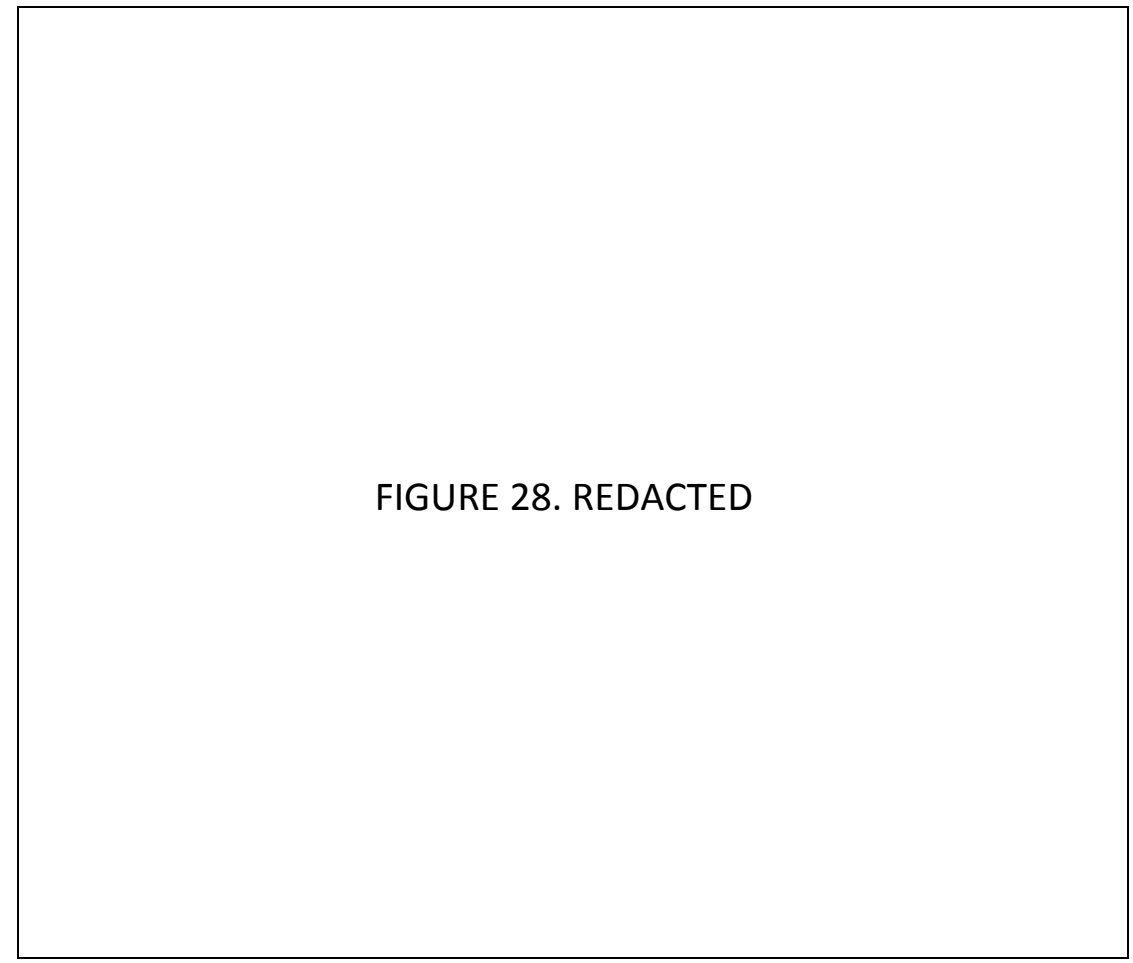

Figure 28. 41TV1667 site map.

\section{Results}

DogLeash Results

A $100 \%$ surface artifact inventory could not be performed on the site due to the poor ground visibility. However, a 5-meter dogleash was performed within a small lithic/FCR scatter (see Figure 28). The scatter was observed in the middle of the northeast 
to southwesterly-running dirt road, and appeared to cover an area approximately $8 \mathrm{~m}$ in diameter, and a 5-m diameter dogleash and surface inventory was performed in its central portion (Table 2).

Table 2. Results of 5-meter diameter dog leash performed on 41TV1667.

\begin{tabular}{|l|r|r|l|l|l|r|}
\hline & & & Unifacially & Bifacially & & \\
\hline & Exterior & Interior & Retouched & Retouched & & \\
\hline Size & Flakes & Flakes & Flakes & Flakes & Cores & FCR \\
\hline$<3 \mathrm{~cm}$ & 3 & 4 & 0 & 0 & 0 & 0 \\
\hline$>3 \mathrm{~cm}$ & 0 & 2 & 2 & 1 & 0 & 10 \\
\hline$>5 \mathrm{~cm}$ & 1 & 0 & 0 & 1 & 0 & 5 \\
\hline$>7 \mathrm{~cm}$ & 0 & 0 & 0 & 0 & 1 & 0 \\
\hline Totals & $\mathbf{4}$ & $\mathbf{6}$ & $\mathbf{2}$ & $\mathbf{2}$ & $\mathbf{1}$ & $\mathbf{1 5}$ \\
\hline
\end{tabular}

Shovel Test Results

In order to determine the extent of vertical and horizontal artifact deposition, a total of 25 shovel tests were excavated within the confines of 41TV1722. A total of 66 artifacts were recovered in 11 of the 25 shovel tests excavated (Table 3 ). 
Table 3. 41TV1667 shovel test artifact inventory.

\begin{tabular}{|c|c|c|c|c|c|c|c|c|c|c|}
\hline & & & Modified & & & & & & & \\
\hline & & Interior & Interior & & & & & & & \\
\hline & Interior & Utilized & Utilized & Exterior & & & Red & Mussel & & \\
\hline ST & Flake & Flake & Flake & Flake & Debitage F & & Hemotite & Shell & Bone 7 & Totals \\
\hline 29 & 0 & 1 & 0 & 0 & $\begin{array}{r}0 \\
\end{array}$ & 0 & 0 & & \begin{tabular}{l|l}
0 & 0 \\
\end{tabular} & \\
\hline 32 & 0 & 0 & 0 & 0 & 0 & 0 & 0 & & 0 & 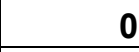 \\
\hline 49 & 6 & 0 & 0 & 3 & 3 & 0 & 0 & & 0 & 12 \\
\hline 50 & 0 & 0 & 0 & 0 & 0 & 0 & 0 & & 0 & \\
\hline 51 & 0 & 0 & 0 & $\underline{0}$ & 0 & 0 & 0 & & 0 & \\
\hline 52 & 0 & 0 & 0 & $\underline{0}$ & 0 & 0 & 0 & & 0 & \\
\hline 53 & 1 & 0 & 0 & 0 & 0 & 0 & $\underline{0}$ & & 0 & \\
\hline 54 & 0 & $\underline{0}$ & $\underline{0}$ & $\underline{0}$ & 0 & 0 & $\underline{0}$ & & 0 & \\
\hline 55 & 0 & 0 & 0 & $\underline{0}$ & 0 & 0 & 0 & & 0 & \\
\hline 56 & 0 & 0 & 0 & 0 & 0 & 0 & 0 & & 0 & \\
\hline 57 & 1 & 0 & 0 & $\underline{0}$ & 0 & 0 & $\underline{0}$ & & 0 & \\
\hline 58 & 0 & 0 & 0 & 0 & 0 & 0 & $\underline{0}$ & & 0 & \\
\hline 59 & 0 & 0 & 0 & 0 & 0 & 0 & $\underline{0}$ & & 0 & 0 \\
\hline 60 & 0 & $\underline{0}$ & 0 & 0 & 0 & 0 & $\underline{0}$ & & 0 & \\
\hline 61 & 6 & 0 & 0 & 0 & 0 & 0 & 0 & & 0 & \\
\hline 62 & 0 & 0 & 0 & 0 & 0 & 0 & $\underline{0}$ & & 0 & \\
\hline 63 & 0 & 0 & 0 & 0 & 0 & 0 & 0 & & 0 & \\
\hline 64 & 5 & 0 & 0 & 0 & 0 & 0 & $\underline{0}$ & & 0 & \\
\hline 65 & 0 & 0 & 0 & 0 & 1 & 0 & 0 & & 0 & 1 \\
\hline 124 & 0 & 0 & 0 & 0 & 0 & 0 & 0 & & 10 & 10 \\
\hline 125 & 0 & 2 & 0 & 0 & 0 & 0 & 0 & & 0 & 2 \\
\hline 126 & 7 & 0 & 1 & 3 & 4 & 3 & 2 & & 0 & 20 \\
\hline 127 & 0 & 0 & 0 & 0 & 0 & 0 & $\underline{0}$ & & 0 & 0 \\
\hline 128 & 0 & 0 & 0 & 0 & 0 & 0 & 0 & & 0 & 0 \\
\hline 129 & 0 & 0 & 0 & 0 & 0 & 6 & 0 & 0 & 0 & 6 \\
\hline Total & 26 & 3 & 1 & 6 & 8 & 9 & 2 & & 10 & 66 \\
\hline
\end{tabular}

Shovel testing revealed the presence of two areas (Areas A and B), which contained multi-component deposits of cultural resources (see Figure28).

Area A

In Area A (located on the northern half of 41 TV1667 subsurface deposits of cultural resources were noted in five excavated shovel tests (STs 61, 64, 65, 124, and 125). The upper cultural component observed within Area A was encountered at approximately $0-25 \mathrm{~cm}$ below surface in all five shovel tests excavated. The excavation of Shovel Tests 61 and 64 revealed a discrete lower cultural component occurring within this area at approximately $30-60 \mathrm{~cm}$ below surface (Table 4). 
Table 4. Shovel tests excavated in Area A. Cumulative artifacts by level.

\begin{tabular}{|r|r|l|r|r|r|r|}
\hline & & Interior & & & & \\
\hline & Interior & Utilized & & Mussel & & \\
\hline Level & Flake & Flake & Debitage & Shell & Bone & Totals \\
\hline 1 & 3 & 1 & 0 & 0 & 0 & $\mathbf{4}$ \\
\hline 2 & 1 & 1 & 0 & 0 & 10 & $\mathbf{1 2}$ \\
\hline 3 & 4 & 0 & 1 & 1 & 0 & $\mathbf{6}$ \\
\hline 4 & 1 & 0 & 0 & 0 & 0 & $\mathbf{1}$ \\
\hline 5 & 1 & 0 & 0 & 0 & 0 & $\mathbf{1}$ \\
\hline 6 & 1 & 0 & 0 & 0 & 0 & $\mathbf{1}$ \\
\hline Total & $\mathbf{1 1}$ & $\mathbf{2}$ & $\mathbf{1}$ & $\mathbf{1}$ & $\mathbf{1 0}$ & $\mathbf{2 5}$ \\
\hline
\end{tabular}

Area B

In Area-B (located on the southern half of 41TV1667) subsurface deposits of cultural resources were encountered in five excavated shovel tests (ST 29, 49, 126, 128, and 129, Table 5). The upper cultural component observed within Area B was encountered at approximately $0-30 \mathrm{~cm}$ below surface in all five shovel tests excavated. The excavation of Shovel Tests 49, 126, and 129 revealed a lower cultural component occurring within this area at approximately $30-100 \mathrm{~cm}$ below surface. Firecracked rock (FCR) was recovered at Area B within ST $126(30-40 \mathrm{~cm} \mathrm{bs})$ and ST $129(40-50 \mathrm{~cm}$ below surface). The presence of FCR at this site indicates that there is an excellent potential for encountering buried hearth/midden features. Area B contained 61 percent of all artifacts collected on the site during the survey.

Table 5. Shovel Tests excavated in Area B. Cumulative artifacts by level.

\begin{tabular}{|r|l|l|l|l|r|r|r|r|}
\hline & & & Modified & & & & & \\
\hline & & Interior & Interior & & & & & \\
\hline & Interior & Utilized & Utilized & Exterior & & & Red & \\
\hline Level & Flake & Flake & Flake & Flake & Debitage & FCR & Hematite & Totals \\
\hline 1 & 2 & 1 & 1 & 0 & 0 & 0 & 0 & $\mathbf{4}$ \\
\hline 2 & 4 & 0 & 0 & 0 & 0 & 3 & 0 & $\mathbf{7}$ \\
\hline 3 & 0 & 0 & 0 & 0 & 1 & 0 & 0 & $\mathbf{1}$ \\
\hline 4 & 1 & 0 & 0 & 1 & 0 & 0 & 0 & $\mathbf{2}$ \\
\hline 5 & 1 & 0 & 0 & 2 & 1 & 6 & 0 & $\mathbf{1 0}$ \\
\hline 6 & 3 & 0 & 0 & 1 & 1 & 0 & 0 & $\mathbf{5}$ \\
\hline 7 & 1 & 0 & 0 & 0 & 1 & 0 & 0 & $\mathbf{2}$ \\
\hline 8 & 2 & 0 & 0 & 2 & 0 & 0 & 2 & $\mathbf{6}$ \\
\hline 9 & 0 & 0 & 0 & 0 & 2 & 0 & 0 & $\mathbf{2}$ \\
\hline 10 & 0 & 0 & 0 & 0 & 1 & 0 & 0 & $\mathbf{1}$ \\
\hline Totals & $\mathbf{1 4}$ & $\mathbf{1}$ & $\mathbf{1}$ & $\mathbf{6}$ & $\mathbf{7}$ & $\mathbf{9}$ & $\mathbf{2}$ & $\mathbf{4 0}$ \\
\hline
\end{tabular}

Backhoe Trenches

No diagnostic artifacts were collected on 41TV1667 during either the pedestrian survey or the shovel test investigations. In order to determine temporal geologic 
sequences and the extent of cultural resources, two backhoe trenches (BHT 1 and 2) were excavated. Backhoe Trench 1 (BHT 1) was placed in the northern half of the site within Area A. Backhoe Trench 2 (BHT 2) was placed in the southern portion of the site within Area B.

\section{BHT 1}

The geologic sequences observed in the profile of BHT 1 revealed the presence of an ancient stream channel, which ran through portions of 41TV1667 during the early Holocene. A total of six stratigraphic soil horizons were identified in the northwest wall of BHT 1 (Figure 29).

The following is a description of the geologic pedon observed within BHT 1:

Zone 1 (O horizon), extended from the surface to $1 \mathrm{~cm}$ below surface. It was comprised of the typical grass, humus, and roots commonly associated with geologic $\mathrm{O}$ horizons.

Zone 2 (A horizon), extending $0-17 \mathrm{~cm}$ below surface, is described as a very dark brown (10YR2/2) silt loam that had a fine-moderate structure and a clear smooth lower boundary. Numerous rootlets and insects burrows were noted within the matrix of BHT 1 , Zone 2.

Zone 3 (B1 horizon), extending 17-24.5 cm below surface, is described as slightly firm very dark grayish-brown (10YR3/2) silty-clay loam that had a fine to weak subangular blocky structure and abrupt irregular lower boundary. Rootlets, limestone pebbles, and a small amount of calcium carbonate were noted within the matrix of BHT 1, Zone 3.

Zone 4 (B2 horizon), extending 24.5-37 $\mathrm{cm}$ below surface, is described as a friable very dark grayish-brown (10YR3/2) clay loam with an abrupt/slightly wavy lower boundary. Numerous matrix supported limestone gravels (up to 4" in diameter), and calcium carbonate nodules were noted within BHT 1, Zone 4.

Zone 5 (B3 horizon), extending 37-77 $\mathrm{cm}$ below surface, is described as a friable dark brown (7.5YR3/3) clay loam with an abrupt/slightly wavy lower boundary. Numerous matrix supported limestone gravels (up to 4" in diameter), and calcium carbonate nodules were noted within the matrix of BHT 1, Zone 5. 


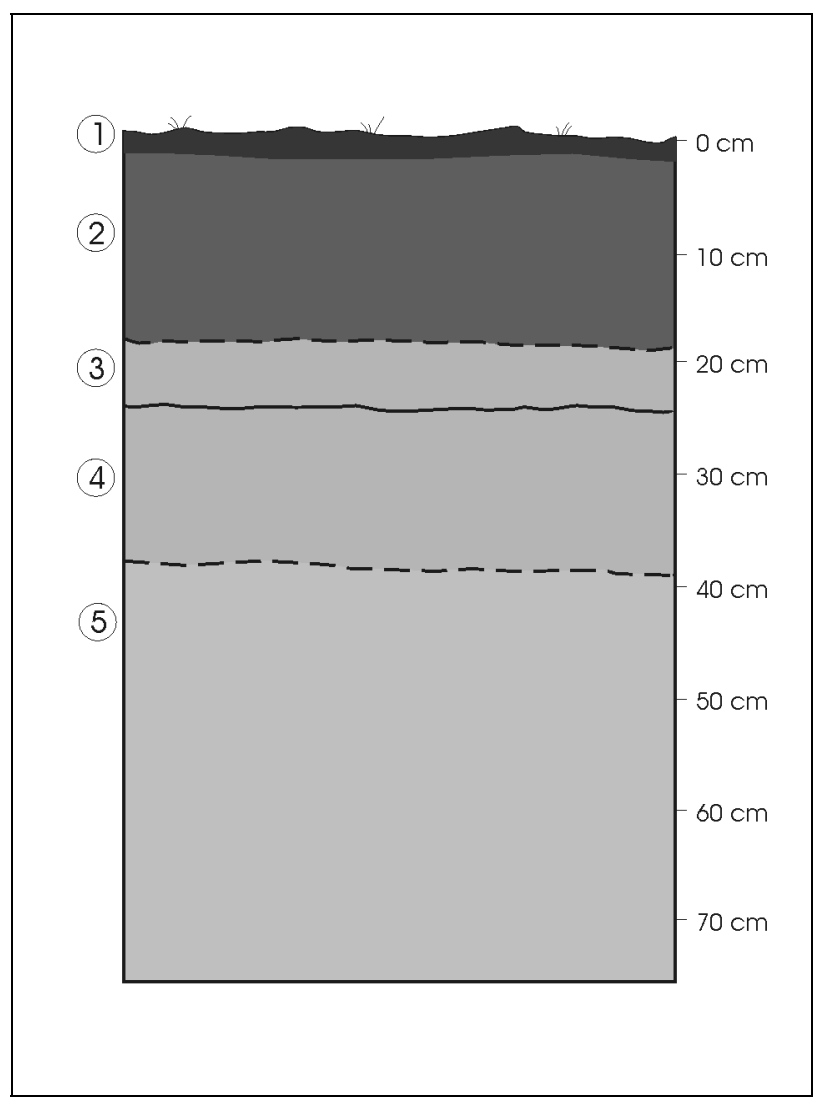

Figure 29. Northern wall of Backhoe Trench 1.

BHT 2

The geologic sequences observed in the profile of BHT 2 revealed that the southern portion of 41TV1667 contained the presence of intact Holocene deposits extending $100 \mathrm{~cm}$ below surface. A total of three stratigraphic soil horizons were identified in the northwest wall of BHT 2 (Figure 30).

The following is a description of the geologic pedon observed within BHT 2:

Zone 1 (O horizon), extended from the surface to $1 \mathrm{~cm}$ below surface. It was comprised of the typical grass, humus, and roots commonly associated with geologic $\mathrm{O}$ horizons.

Zone 2 (A horizon), extending 0-14 cm below surface, is described as a very dark gray (10YR3/1) clay loam that had a medium to moderate sub-angular blocky structure and clear smooth lower boundary. Common rootlets, snail shells, and insect burrows were noted within the matrix of BHT 2, Zone 2.

Zone 3 (B1 horizon), extending 14-100+ $\mathrm{cm}$ below surface, is described as brown (7.5YR4/4) clay loam that had a sub-angular to angular blocky structure with no lower 
boundary observed. Numerous snail shells were noted within the matrix of BHT 2, Zone 3.

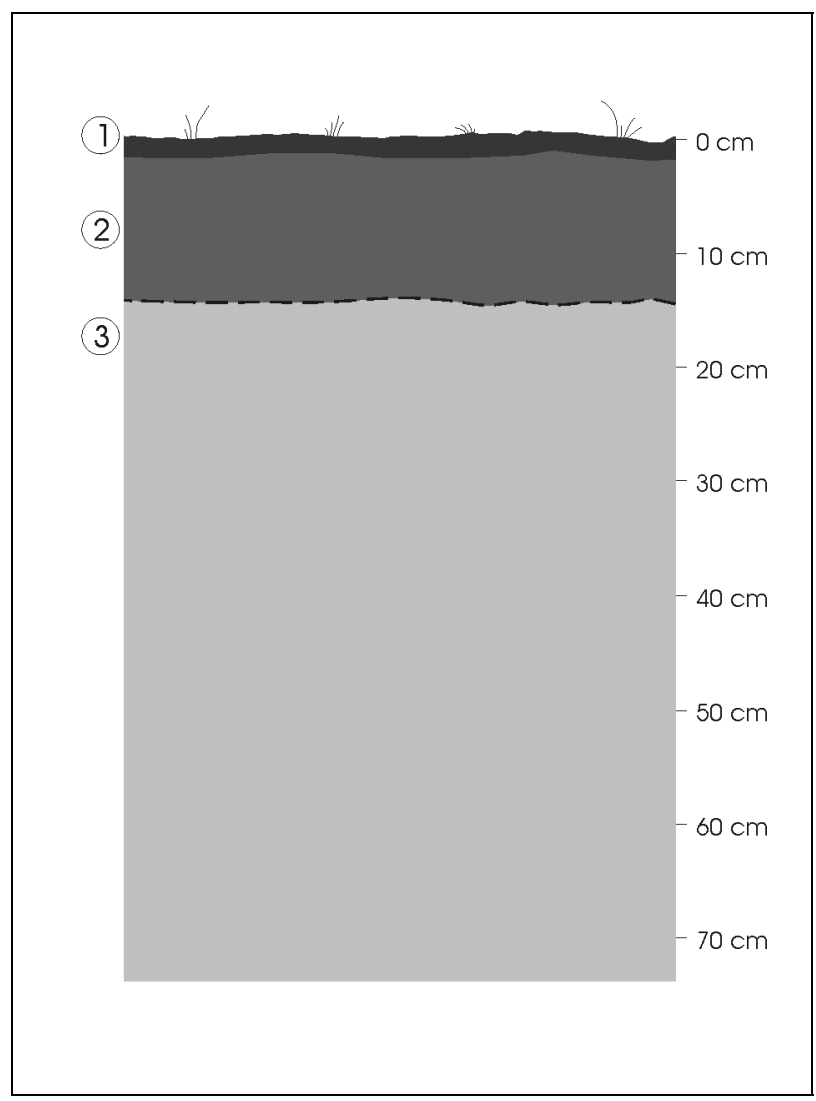

Figure 30. Northern wall of Backhoe Trench 2.

\section{$41 T V 1954$}

Prehistoric site 41TV1954 was discovered $45 \mathrm{~m}$ north of 41TV1722, on a slight upland setting in the west-central portion of Camp Mabry (Figures 31 and 32). According to Werchen et al. (1974), the soils observed at 41TV1954 are of the Tarrant (TeA) series classification. In non-developed areas, Tarrant soils are described as being a dark grayishbrown clay or clay loam, which extends 8 inches below the surface. Below 8 inches, limestone bedrock typically forms the underlying component in TeA soil types (Werchen et al. 1974). At the time of the survey, thick brush (e.g., greenbrier and cedar) covered approximately 70 percent of the site, thus limiting site surface visibility to approximately 30 percent. Upon examination, the site appeared to be heavily disturbed by natural impacts. Extensive water erosion has exposed the underlying limestone bedrock in approximately 30 percent of the site. In addition, a moderate amount of trash refuse was scattered across the site. 


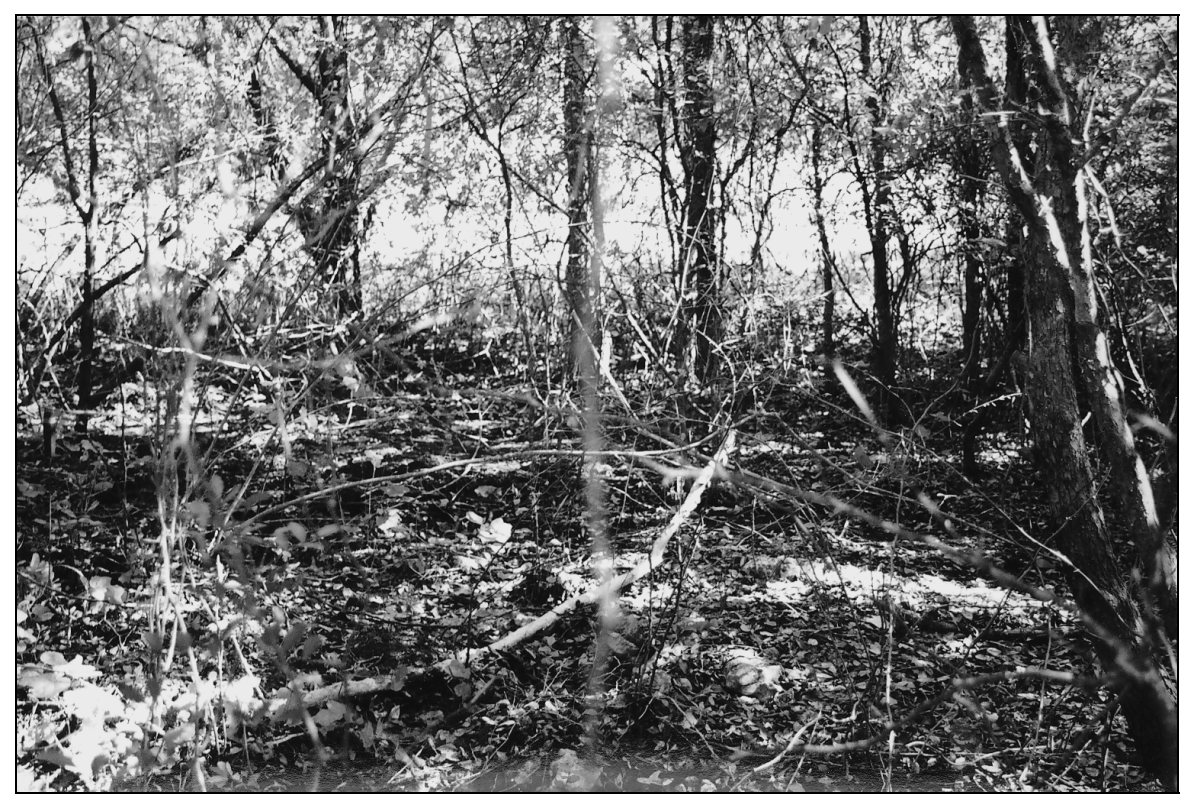

Figure 31. 41TV1954 facing north.

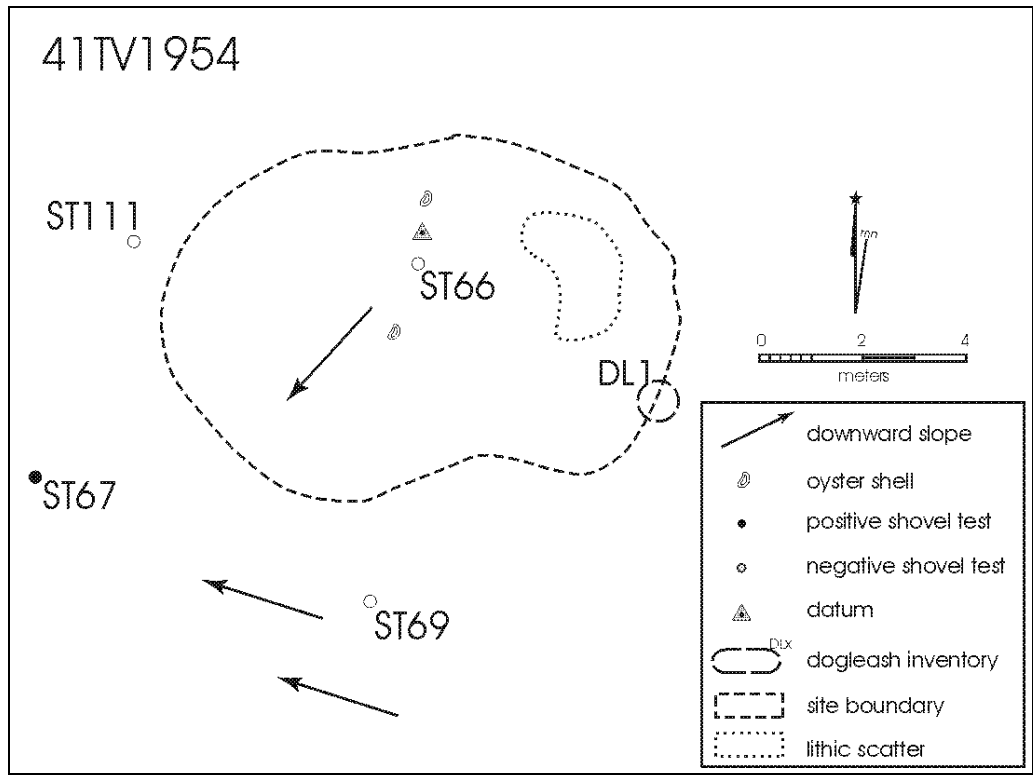

Figure 32. 41TV1954 site map.

\section{Results}

Dogleash Results

A 100 percent surface artifact inventory could not be preformed on the site due to the poor ground visibility. However, a 5-m dogleash (Figure 32) was performed in the eastern portion of the site in an area where a small amount of cultural material was noted 
on the surface. By documenting the extent of surface artifact distribution, the site was found to be approximately 8 - $x-8$-meters in size.

Table 6. Results of 5-m diameter dogleash performed on 41TV1954.

\begin{tabular}{|c|c|c|}
\hline & Interior & \\
\hline Size & Flakes & Cores \\
\hline$<3 \mathrm{~cm}$ & 1 & 0 \\
\hline$>3 \mathrm{~cm}$ & 0 & 1 \\
\hline$>5 \mathrm{~cm}$ & 1 & 0 \\
\hline$>7 \mathrm{~cm}$ & 0 & 0 \\
\hline Totals & $\mathbf{2}$ & $\mathbf{1}$ \\
\hline
\end{tabular}

\section{Shovel Test Results}

In order to determine the extent of vertical and horizontal artifact deposition, six shovel tests were excavated within the confines of 41TV1954. Shovel Test 67 contained the only subsurface artifact collected on $41 \mathrm{TV} 1954$ (one piece of metal at 0-10 cm below surface). 


\section{Chapter 8: Summary}

By Richard S. Jones

\section{Introduction}

The archaeological survey conducted on Camp Mabry generally succeeded in generating data that supports some of the research issues that were relayed in the historic context section of this report (see Chapter 5). However, since this project is considered a Phase 1 inventory study, the research issues outlined in the Historic Context Section were covered in a limited fashion. Large-scale archaeological investigations with feature excavations are needed to fully elaborate on, and expand, Camp Mabry's research issues to the fullest. During this survey, the majority of the prehistoric research issues discussed (i.e., hunter gatherer lithic technology and assemblage, and prehistoric subsistence and adaptation) were supported by work conducted on site 41TV1667, 41TV1722, and 41TV1954. Unfortunately, no intact historic features relating to the historic research issues were encountered during the survey (i.e., historic homesteads/structures). Numerous historic artifacts were observed on Camp Mabry, however, they were observed dispersed throughout the project area within disturbed contexts. As previously stated in Chapter 5, there is a possibility that both historic and prehistoric resources were covered and impacted when the numerous artificial terraces (see Chapter 2) were constructed on Camp Mabry.

\section{Evaluation of Prehistoric Research Issues}

As previously stated, data generated from work conducted on $41 \mathrm{TV} 1667$ did relate to the prehistoric research issues outlined in the historic context section. The following is a brief summary describing how work conducted on prehistoric site 41TV1667 provided information which relates to: (1) prehistoric subsistence and adaptation, and (2) hunter-gatherer lithic technology and assemblage.

\section{Prehistoric Subsistence and Adaptation}

Extensive shovel testing on 41TV1667 revealed the presence of buried bone (10 pieces recovered in Level 2 at Area A) and FCR (at Level 2 and Level 5 in Area B). As previously stated in Chapter 5, archaeological sites in Central Texas generally do not have a high degree of biotic preservation. Thus, any biotic remains recovered during this survey should be considered highly significant and, hopefully could provide important clues relating to the specific type of floral/faunal resources being consumed, along with the seasonality of exploitation. The presence of buried, intact bone could indicate that the subsurface geology of 41TV1667 is conducive to the preservation of biotic materials, thus there is a good chance that additional intact biotic remains are buried at the site. 
The FCR recovered during the excavation of two shovel tests in Area B of 41TV1667 could indicate the presence of buried burned rock hearths or midden features within this portion of the site. As previously stated in Chapter 5, the careful examination of burned rocks can provide some interesting scientific insights regarding prehistoric human subsistence and adaptation. In addition, when the size and density of burned rock features are analyzed at a site, scientific inferences can be generated regarding group mobility, size, and length of occupation.

\section{Hunter-Gatherer Lithic Technology and Assemblage}

The most difficult research issue encountered in this survey was addressing how the technology and assemblage of lithic artifacts collected/observed at Camp Mabry directly relate to group mobility. Numerous factors such as: 1) the small number of sites located within the project area; 2 ) the small amount of artifacts collected/observed; 3 ) the highly disturbed nature of the project area; 4) no diagnostic artifacts observed and/or collected; and 5) the documented occurrence of looting within Camp Mabry all contributed to making this research theme extremely difficult to address. The following is a brief outline of the methodology employed and issues faced while trying to address this important research topic.

In order to address the question of how lithic technology relates to mobility within the project area, the few expedient and curated surface artifacts recorded within the dogleashes and site inventories of the three sites tested during the survey were analyzed and the adjusted residuals compared. Adjusted residuals are a form of analysis devised for contingency tables, which measures the observed variability from the expected pattern (Norusis 1999). For this survey, a 5\% level of significance was employed, which equates to a 1.96 cutoff value of the adjusted residual (Table 7). Thus, any adjusted residual that is greater or less than 1.96 is considered to be highly significant, or greater than what is normally expected.

Table 7. Contingency table showing the quantity and adjusted residuals of surface artifacts recorded on 41TV1667, 41TV1722, and 41TV1954.

Adjusted residual values are in parentheses.

\begin{tabular}{|c|c|c|c|}
\hline & Expedient & \multicolumn{2}{|l|}{ Expensive } \\
\hline & Unifaces \& & Bifaces \& & \\
\hline Site & Ext. Flakes & Int. Flakes & Total \\
\hline 41TV1667 & $4(-0.72)$ & $10(0.72)$ & 14 \\
\hline 41TV1722 & $43(1.09)$ & $67(-1.09)$ & 110 \\
\hline 41TV1954 & $0(-1.1)$ & $2(1.1)$ & 2 \\
\hline Total & 47 & 79 & 126 \\
\hline
\end{tabular}

The adjusted residuals generated within the contingency table reflect values well within what is normally expected. Based on the data generated in Table 7 it could be speculated that; 1) none of the sites appear to be intensively utilized by just foragers 
and/or collectors; and 2) the Camp Mabry project area appears to have been equally utilized by both foragers and collectors (therefore producing adjusted residual values below the 5\% level of significance). If an adjusted residual above the 5\% (1.96) level of significance did happen to occur within Table 7, one could then speculate that the site and/or sites were, more than likely, predominately utilized by either foragers or collectors.

Based on what the data generated within Table 7 suggested, a conclusion that the Camp Mabry project area was occupied and equally utilized by both collectors and foragers is implied. However, two sites within Camp Mabry (41TV1721 and 41TV1667) had been intensively surface collected (i.e., looted) for the past 20+ years (see Chapter 3 . Previous Investigations). Since surface collectors tend to primarily collect fine, curated tools (e.g., projectile points, bifaces) over expedient tools, the three sites visited during this survey could, at one point, have had high quantities of curated artifacts. Surface collecting within the project area is more than likely statistically biasing the adjusted residual values generated for the one site tested (41TV1667) that has a documented history of being looted (State of Texas Archaeological Site Data Form, on file at the Texas Archeological Research Laboratory, The University of Texas at Austin). Thus, the adjusted residual for 41TV1667 is more than likely actually higher than what is being displayed in Table 7. Without documented evidence of prior looting (i.e., information on a State of Texas site survey form, or personal interviews, etc...), the validity of the adjusted residuals recorded in 41 TV1722 and 41TV1954 could be considered accurate and highly reflective of what is happening within the project area. However, due to the presence of intensive long term looting within the project area at two nearby sites (41TV1721 and 41TV1667), the likelihood of looters not also visiting sites 41TV1954 and 41TV1722 should be considered quite remote, and therefore the true reliability of the adjusted residuals generated for these two sites should not be trusted to a high degree.

\section{Summary}

\section{TV1667}

As previously discussed, the 20+ years of documented looting at 41TV1667 has definitely made it very difficult to determine group mobility based on the analysis of the lithic technology and assemblage of artifacts recorded on the site's surface. Due to the presence of extensive looting at this site, the degree to which the site was occupied by either foragers or collectors remains unknown. Additional subsurface testing (i.e., 1-x-1meter units) is needed in order to clarify this problematic issue.

\section{TV1722 and $41 T V 1954$}

As previously stated, the adjusted residual values generated for these two sites (see Table 7) indicate that the artifacts recorded in both sites fall within a normal range of 
what is to be expected. Thus, both foragers and/or collectors could have utilized both of these sites in antiquity. The validity of the adjusted residuals for 41TV1722 and 41TV1954 could be considered accurate and highly reflective of what is happening within the project area. However, as previously stated, like 41TV1667 and 41TV1721 (see Chapter 3), these two sites could have also been impacted by looting. Since looting has occurred at two nearby sites, the adjusted residual values generated in Table 7 should be regarded as highly suspect. 


\section{Chapter 9: Conclusions and Recommendations}

By Richard S. Jones

\section{Introduction}

In October 2001, the Center for Archaeological Studies conducted an intensive 275-acre archaeological survey within the confines of AGTX's Camp Mabry. The survey resulted in the discovery of prehistoric site 41TV1954 in the west-central portion of the camp. In addition, two previously recorded archaeological sites, 41TV1722 and 41TV1667, were revisited in order to reevaluate their eligibility potential for nomination to the National Register of Historic Places (NHRP). As previously stated, the NRHP eligibility recommendations made by CAS fell into one of three categories: 1) eligible, 2) not eligible, or 3) further investigation needed.

\section{Recommendations}

\section{Not Eligible}

Based on results gathered during survey, CAS recommended that prehistoric site 41TV1722 and 41TV1954 do not qualify for consideration to the National Register of Historic Places. Due to the extensive natural and artificial impacts observed at 41TV1722 and 41TV1954, the contextual integrity of both of these sites was extremely poor in nature. It is our opinion that both sites contain no potential to contribute to a better understanding of the prehistory of Central Texas, beyond the records provided within this report. Therefore, I recommend that no further archaeological investigation is warranted.

\section{Further Investigation Needed}

Based on results gathered during the survey, CAS recommends that further investigation is needed on prehistoric site 41TV1667 in order to determine its eligibility potential for nomination to the NRHP. Despite the large amount of natural and artificial impacts noted within 41TV1667, the areas where the deepest deposits of cultural resources were observed (Areas A and B) appear to be relatively undisturbed in nature. It appears that, in antiquity, this portion of 41 TV1667 was in a geographic location which prevented soil agradation and allowed a degree of Holocene soil accumulation. Deep Holocene deposits were not encountered anywhere else during the 275 -acre survey. The presence of buried deposits of both FCR and faunal remains at 41TV1667 indicates that this site does have the potential to provide significant information regarding the prehistoric adaptation and subsistence strategies employed by the inhabitants of Central Texas during the middle to late Holocene. Due to the $60 \mathrm{~cm}$ to $1 \mathrm{~m}$-deep Holocene 
deposits noted within these areas, and presence of buried faunal and FCR deposits, the research value of this site should be regarded as moderate to high in nature. CAS therefore recommends that further investigation will be warranted if future development or impacts are slated to occur at this site. The results of these investigations should provide the additional data needed in order to make an NRHP eligibility determination. 


\section{References Cited}

Andrefsky, W., Jr.

1991 Inferring Trends in Prehistoric Settlement Behavior From Lithic Production

Technology in the Southern Plains. North American Archaeologist 12:129-44.

Austin.

2002 The Handbook of Texas Online.

http://www.tsha.utexas.edu/handbook/online/articles/view/AA/hda3.htmI

Accessed Wed Feb 3 10:44:44 US/Central 2002.

Austin American (AA) [Austin, Texas]

1953 "Colorful Mule Skinner Dies." 15 July. Austin, Texas.

1956 "Fire Levels Old Mansion in Foothills." 29 February. Austin, Texas.

Austin American-Statesman (AAS). [Austin, Texas]

1956 "Division into Homesites Planned for Famous Old Huck Estate." 13 April.

Austin, Texas.

Austin Statesman $(A S)$ [Austin, Texas]

1953 "C. H. Deison Funeral Set For Thursday." 15 July. Austin, Texas

1905 "At Least 10,000 Visitors are Expected." 23 August. Austin, Texas.

Austin Daily Statesman (ADS). [Austin, Texas]

1894 "Camp Mabry." 14 July. Austin, Texas.

1894 "The Sham Battle." 18 July. Austin, Texas.

1892 "The Fifth Day." 17 July. Austin, Texas.

1895 "The Emancipation Day Picnic." 19 June. Austin, Texas.

Austin Statesman $(A S)$ [Austin, Texas]

1927 "Hills and River Hide One of City's Most Beautiful Homes:" 17 April.

Austin, Texas.

1953 "Francis Huck, Survivor of Hurricanes on Gulf Coast, Is Buried in Victoria." 16 November. Austin, Texas.

1956 "Fire Razes Old Homesite in Foothills." 29 February. Austin, Texas.

Balcones Fault Zone of Austin

2002 http://www.utexas.edu/ftp/student/geo/ggtc/ch3.html. Accessed 2/15/2002, 10:12:11 AM.

Bamforth, D. B.

1986 Technological Efficiency and Tool Curation. American Antiquity 51:38-50. 
Barkley, M. S.

1967 [1963] History of Travis County and Austin, 1839-1889. The Steck Company, Austin.

Baumgartner, D., W.C. Foster, and J. Jackson

1997 Frontier River: Exploration and Settlement of the Colorado River. Lower Colorado River Authority, Austin.

Binford, L. R.

1973 Interassemblage Variability - the Mousterian and the "Functional" Argument. In The Explanation of Culture Change, edited by C. Renfrew, pp. 227-254. London Press.

1979 Organization and Formation Processes: Looking at Curated Techniques. Journal of Anthropological Research 35(3):255-273.

1980 Willow Smoke and Dogs' Tails: Hunter-Gatherer Settlement Systems and Archaeological Site Formation. American Antiquity 45:4-20.

1983 In Pursuit of the Past: Decoding the Archaeological Record. Thames and Hudson, New York.

Black, S. L.

1989a South Texas Plains. In From the Gulf to the Rio Grande: Human Adaptation in Central, South and Lower Pecos Texas, by T. R. Hester, S. L. Black, D. G. Steele, B. W. Olive, A. A. Fox, K. Reinhard, and L. C. Bement, pp. 39-62. Research Series No. 33. Arkansas Archeological Survey, Fayetteville.

1989b Environmental Setting. From the Gulf Coast to the Rio Grande: Human Adaptation in Central, South, and Lower Pecos Texas, by T. R. Hester, S. L. Black, D. G. Steele, B. W. Olive, A. A. Fox, K. J. Reinhard, and L. C. Bement, pp. 5-17. Research Series No. 33. Arkansas Archeological Survey, Fayetteville.

1989c Central Texas Plateau Prairie. In From the Gulf to the Rio Grande: Human Adaptation in Central, South, and Lower Pecos Texas, by T. R. Hester, S. L. Black, D. G. Steele, B. W. Olive, A. A. Fox, K. J. Reinhard, and L. C. Bement, pp. 5-16. Research Series No. 33. Arkansas Archeological Survey, Fayetteville.

Black, S. L., K. Jolly, and D. R. Potter

1993 The Higgins Experiment: Field Report. Wurzbach Project Working Papers. Texas Archeological Research Laboratory, The University of Texas at Austin.

Black, S. L., L. W. Ellis, D. G. Creel, and G. T. Goode

1997 Hot Rock Cooking on the Greater Edwards Plateau: Four Burned Rock Midden Sites in West Central Texas (two volumes). Studies in Archeology 22. Texas Archeological Research Laboratory, The University of Texas at Austin. Texas Department of Transportation Environmental Affairs Department, Archeology Studies Program, Report 2.

Blair, F.

1950 The Biotic Provinces of Texas. Texas Journal of Science 2(1):93-117. 
Bleed, P.

1986 The Optimal Design of Hunting Weapons: Maintainability or Reliability. In American Antiquity 51:737-747.

Bousman, C. B.

1991 Holocene Paleoecology and Later Stone Age Hunter-Gatherer Adaptations in the South African Interior Plateau. Unpublished Ph.D. dissertation. Southern Methodist University, Dallas.

1993 Hunter-Gatherer Adaptations, Economic Risk and Tool Design. In Lithic Technology 18(1\&2):59-86.

Brown, F.

n.d. "Annals of Travis County and the City of Austin (From the Earliest Time to the Close of 1875)." Typescript (32 volumes) in Austin History Center, Austin Public Library, Austin.

Bureau of Economic Geology

1996 River Basin Map of Texas. Bureau of Economic Geology, The University of Texas at Austin.

Camp Mabry

2002 The Handbook of Texas Online. $<$ http://www.tsha.utexas.edu/handbook/online/articles/view/CC/qbc18.html> [Accessed Fri Mar 28 10:34:44 US/Central 2002].

Carpenter, V. K. (transcriber)

1969 State of Texas Federal Population Schedules, Seventh Census of the United States 1850. Century Enterprises. Huntsville, Arkansas.

Chapman, R. C., and J. A. Schutt

1997 Methodology of Lithic Analysis. In Archeological Investigations in Cochiti Reservoir, New Mexico (Vol. 2), Excavation and Analysis, 1975 Season, edited by B. Chapman and J. Biella, pp. 83-96. Office of Contract Archeology, The University of New Mexico at Albuquerque.

Chipman, D. E.

1992 Spanish Texas, 1519-1821. University of Texas Press, Austin.

Collins, M. B.

1995 Forty Years of Archeology in Central Texas. Bulletin of the Texas Archeological Society 66:361-400.

Collins, M. B., and A. C. Kerr

1992 Archeology of the Earliest Texans. Paper presented at the 1992 Annual Meeting, Texas Archeological Society, Laredo. 
Collins, M. B., J. C. Lohse, D. C. Werneke, S. Dornheim, M. Melton, M Shoberg, and A. Malof

2002 The Lampasas Cut Plain Revisited: From Paleoindians to Pioneers Part 2. In Texas Archeology: The Newsletter of the Texas Archeological Society 46(1):3-7.

Collins, M. B., and K. M. Brown

2000 The Gault Gisement: Some Preliminary Observations. In Current Archeology in Texas 2(1):8-11.

Cutrer, T.

1996 "Hancock, George Duncan." The New Handbook of Texas (NHT) 3:438. Texas State Historical Association, Austin.

Daily Democratic Statesman (DDS) [Austin Texas]

1878 "Local News." March 9; March 13; May 21; June 1; July 28.

1879 "Local News." April 22; July 2; and July 9.

1882 "Local News." July 9.

\section{EARDC}

2002 http://www.eardc.swt.edu/. Accessed Mon Jan 21 09:03:33 AM.

Fox, D. E.

1983 Traces of Texas History, Archaeological Evidence of the Past 450 Years. Corona Publishing Company, San Antonio.

Friend, L. B.

1996 "Townes, Robert J." In the NHT 6:539. Texas State Historical Association, Austin.

Gould, F. W.

1969 Texas Plants: A Checklist and Ecological Summary. Texas Agricultural Experimental Station Bulletin MP-585, College Station.

Gracy, A. D. and E. G. S. Genter

1967 Travis County, Texas: The Five Schedules of the 1860 Federal Census. Privately published, Austin.

Hazelwood, C.

1996 "Waterloo, Texas." In the NHT 6:843. Texas State Historical Association, Austin.

Hart, K.

1956 "Interview with Col. Thomas Adams Doxey, Jr. Austin 1956." In "James Dougherty Doxey" AF Biography file, Austin History Center, Austin Public Library. 
Heligbrodt, E. (compiler)

1943 "History of Camp Mabry (Compiled from the Reports of the Adjutants General of Texas in 1943)," typescript in "Camp Mabry" AF manuscript file, Austin History Center, Austin Public Library.

Hester, T. R.

1995 The Prehistory of South Texas. Bulletin of the Texas Archeological Society $66: 427-459$.

Huebner, J. A.

1991 Late Prehistoric Bison Populations in Central and Southern Texas. Plains Anthropologist 36(137):343-358.

Jordan, M. A.

2002 The Balcones Fault Zone of Austin http://www.utexas.edu/ftp/student/deo/ggtc/ch3.html Accessed 2/15/2002, 10:12:11AM.

Kerr, A. C.

2000 Systematic Analysis of Unfluted Lanceolate Projectile Points. Unpublished Masters Thesis, University of Texas at Austin.

Kibler, K. W. and A. Scott

2000 Archaic Hunters and Gatherers of the Balcones Canyonlands: Data Recovery at the Cibolo Crossing Site (41BX377), Camp Bullis Military Reservation, Bexar County, Texas. Reports of Investigations, Number 126. Prewitt and Associates, Inc., Austin, Texas.

Lake Travis

2002 The Handbook of Texas Online. $<$ http://www.tsha.utexas.edu/handbook/online/articles/view/LL/rol79.html > [Accessed Thur Mar 27 10:34:44 US/Central 2002].

Leach J. D., and C. B. Bousman

2001 Cultural and Secondary Formation Processes: On the Dynamic Accumulation of Burned Rock Middens. In Test Excavations at the Culebra Creek Site, 41BX126, Bexar County, Texas, by D. L. Nickels, C. B. Bousman, J. D. Leach, and D. A. Cargill, pp. 119-145. Archaeological Survey Report, No. 265. Center for Archaeological Research, The University of Texas at San Antonio.

Leffler, John J.

1991 From the Shadows into the Sun: Americans and the Spanish-American War. Unpublished Ph.D. dissertation on file, University of Texas at Austin. 
McGraw, A. J., J. W. Clark, and E. A. Robbins (editors)

1991 A Texas Legacy, the Old San Antonio Road and the Caminos Reales: A

Tricentennial History, 1691-1991. Texas State Department of Highways and Public Transportation, Highway Design Division, Austin.

Martin, P. and R. Klein

1989 Quaternary Extinctions: A Prehistoric Revolution. University of Arizona Press, Tucson.

Massanet, D.

1932 [1691] The Expedition of Don Domingo Teran de los Rios into Texas. Translated by M. A. Hatcher. In Preliminary Studies of the Texas Catholic Historical Society 2, No. 1, pp. 48-67.

Meltzer, D. J., and M. R. Bever

1995 Paleoindians of Texas: An Update on the Texas Clovis Fluted Point Survey. Bulletin of the Texas Archeological Society 66:47-81.

Moody, M. C., (compiler)

19911890 Travis County, Texas Census, Uniquely Reconstructed and Annotated. 2 Volumes. Blackstone Publishing Company, Arlington, Texas.

Nickels, D. L.

2000 The Biesenbach Site (41WN88): A Case Study in Diet Breadth. Unpublished M.A. Thesis. Department of Anthropology, University of Texas at San Antonio.

Norusis, M. J.

1999 SPSS for Windows: Base System User's Guide, Release 8.0. SPSS, Chicago.

Olson, Bruce

1996 "Texas National Guard." in the NHT 6:366-371. Texas State Historical Association, Austin.

W.H. Parish Publishing Co.

1894 Artwork of Austin. W.H. Parish Publishing Co., Chicago.

Parry, W., and R. Kelly

1987 Expedient Core Technology and Sedentism. The Organization of Core

Technology, edited by J. Johnson and C. Morrow, pp. 285-309. Westview Press, Boulder.

Pohl, Bill

1962 Balcones Drive. Typescript in "Edgemont" AF manuscript on file, Austin History Center. Austin Public Library, Austin. 
Potter, D. R., S. L. Black, and K. Jolly

1995 Archeology Along the Wurzbach Parkway: Module 1 Introduction, Conceptual Framework, and Contexts of Archeological Investigations in Bexar County, South Central Texas. Studies in Archeology, No. 18. Texas Archeological Research Laboratory, The University of Texas at Austin.

Prewitt, E. R.

1974 Archeological Investigations at the Loeve-Fox Site, Williamson County, Texas. Research Report 49. Texas Archeological Survey, The University of Texas at Austin.

1981 Cultural Chronology in Central Texas. Bulletin of the Texas Archeological Society 52:65-89.

1985 [1983] From Circleville to Toyah: Comments on Central Texas Chronology. Bulletin of the Texas Archeological Society 54:201-238.

1991 Burned Rock Middens: A Summary of Previous Investigations and Interpretations. In The Burned Rock Middens of Texas: An Archeological Symposium, edited by T. R. Hester, pp. 25-32. Studies in Archeology 13, Texas Archeological Research Laboratory, The University of Texas at Austin.

Schiffer, M. B.

1975 The Effects of Occupation Span on Site Content. The Cache River Project, edited by M. B. Schiffer and J. House, pp. 265-269. Arkansas Archaeological Survey, Fayetteville.

1987 Formation Processes of the Archaeological Record. University of New Mexico Press, Albuquerque.

Shott, M J.

1989 On Tool-Class Use Lives and the Formation of Archaeological Assemblages. American Antiquity 54(1):9-30.

Smyrl, V. E.

1996a "Merrilltown, Texas." in the NHT 4:636. Texas State Historical Association, Austin.

1996b "Travis County." In the NHT 6:553-556. Texas State Historical Association, Austin.

Southern Intelligencer (SI)

1859 "Townes, Robert J." vertical file, Center for American History. University of Texas at Austin.

Spanish Missions

2002 The Handbook of Texas Online htp//www.tsha.utexas.edw/handbook/online/articles/view/SS/its2.html[Accessed Wed Mar 26 10:44:44 US/Central 2002]. 
Spearing, D.

1991 Roadside Geology of Texas. Roadside Geology Series, Mountain Press Publishing Co., Missoula, Montana.

Story, D. A.

1985 Adaptive Strategies of Archaic Cultures of the West Gulf Coastal Plain. In Prehistoric Food Production in North America, edited by R. I. Ford, pp. 19-56. Anthropological Papers No. 75, Museum of Anthropology, University of Michigan, Ann Arbor.

Texas Department of Water Resources

1981 A Summary of Weather in Austin. Texas Department of Water Resources, Austin.

Texas Water Development Board

1990 Major Aquifers of Texas: Macro- and Microscale Approaches. In HunterGatherers: An Interdisciplinary Perspective, edited by C. Panter-Brick, R. H. Layton, and P. Rowley-Conly, pp. 73-98. Biosocial Society Symposium Series, Volume 13, Cambridge University Press, Cambridge.

Tomka, S. A.

1999 The Effect of Processing Requirements on Reduction Strategies and Tool Form: A New Perspective. Paper presented at the 64th Annual meeting of the Society for American Archaeology in the symposium entitled: Morphology, Myth, and Meaning: New Directions in Lithic Debitage Analysis.

Torrence, R.

2001 Hunter-Gatherer Technology: Macro- and Microscale Approaches. In HunterGatherers: An Interdisciplinary Perspective, edited by C. Panter-Brick, R. H. Layton, and P. Rowley-Conly, pp. 73-98. Biosocial Society Symposium Series, Volume 13, Cambridge University Press, Cambridge.

Travis County

2002 The Handbook of Texas Online. http://www.tsha.utexas.edu/handbook/online/articles/view/CC/qbc18.html [Accessed Tue Feb 2 9:44:44 US/Central 2002]

Turner, E. S., and T. R. Hester

1999 A Field Guide to Stone Artifacts of Texas Indians. Second Edition, Texas Monthly Field Guide Series, Gulf Publishing. Houston.

Tyler, R. (editor)

1996 "Day, James Monroe." In the NHT 2:543. Texas State Historical Association, Austin. 
Vierra, B.J.

1998 41MV120: A Stratified Late Archaic Site in Maverick County, Texas .Archaeological Survey Report, No. 251. Center for Archaeological Research, The University of Texas at San Antonio.

Weir, F. A.

1976 The Central Texas Archaic. Unpublished Ph.D. dissertation, Department of Anthropology, Washington State University, Pullman.

Weir, F. A., and A. K. Briggs

1997 Proposed Spicewood Springs City Park Hike and Bike Trail, Travis County, Texas. Lone Star Archaeological Services and Weir Enterprises, Austin.

Werchan, L. E., A. C. Lowther, and R. N. Ramsey

1974 Soil Survey of Travis County, Texas. United States Department of Agriculture, Soil Conservation Service. In Conjunction with the Texas Agricultural Extension Station, Washington, D. C.

White, G. (editor)

1966 The 1840 Census of the Republic of Texas. Pemberton Press, Austin.

Willey, G. R.

1966 An Introduction to American Archaeology. Prentice Hall, New York.

Woodruff, C. M., Jr.

1975 Land Capability in the Lake Travis Vicinity, Texas: A Practical Guide for the Use of Geologic and Engineering Data. Report of Investigations 84, Bureau of Economic Geology, The University of Texas at Austin.

Woodruff, C. M., Jr., and P. L. Abbott

1986 Stream Piracy and Evolution of the Edwards Aquifer Along the Balcones Escarpment, Central Texas. In The Balcones Escarpment: Geology, Hydrology, Ecology, and Social Development in Central Texas, edited by P. L. Abbott and C. M. Woodruff Jr., pp. 77-90. Geological Society of America, Austin. 